\title{
Mechanisms for folding of high-grade rocks in extensional tectonic settings
}

\author{
Lyal B. Harris ${ }^{\mathrm{a}, *}$, Hemin A. Koyi ${ }^{\mathrm{b}}$, Haakon Fossen ${ }^{\mathrm{c}}$ \\ ${ }^{\mathrm{a}}$ Tectonics Special Research Centre, Department of Geology and Geophysics, The University of Western Australia, \\ 35 Stirling Highway, Crawley 6009, Australia \\ ${ }^{\mathrm{b}}$ Hans Ramberg Tectonic Laboratory, Institute of Earth Sciences, Uppsala University, Villavägen 16, Uppsala S-752 36, Sweden \\ ${ }^{\mathrm{c}}$ Department of Geology, University of Bergen, Allégaten 41, N-5007 Bergen, Norway
}

Received 4 May 2001; accepted 4 February 2002

\begin{abstract}
This review of structures developed in extensional high-grade terrains, combined with results of centrifuge analogue modelling, illustrates the range of fold styles and mechanisms for folding of amphibolite to granulite facies rocks during rifting or the collapse of a thrust-thickened orogen. Several extensional fold mechanisms (such as folding within detachment shear zones) are similar to those in contractional settings. The metamorphic $P-T-t$ path, and not fold style or mode of formation, is therefore required to determine the tectonic setting in which some folds developed. Other mechanisms such as rollover above and folding between listric normal shear zones, and folding due to isostatic adjustments during crustal thinning, are unique to extensional tectonic settings. Several mechanisms for folding during crustal extension produce structures that could easily be misinterpreted as implying regional contraction and hence lead to errors in their tectonic interpretation. It is shown that isoclinal recumbent folds refolded by open, upright folds may develop during regional extension in the deep crust. Folds with a thrust sense of asymmetry can develop due to high shear strains within an extensional detachment, or from enhanced back-rotation of layers between normal shear zones. During back-rotation folding, layers rotated into the shortening field undergo further buckle folding, and all may rotate towards orthogonality to the maximum shortening direction. This mechanism explains the presence of many transposed folds, folds with axial planar pegmatites and folds with opposite vergence in extensional terrains. Examples of folds in high-grade rocks interpreted as forming during regional extension included in this paper are from the Grenville Province of Canada, Norwegian Caledonides, Albany Mobile Belt and Leeuwin Complex of Western Australia, Ruby Mountains in the Basin and Range Province of Nevada, the Atâ Sund area of Greenland, the Napier Complex of Enderby Land in East Antarctica and the Kigluaik Mountains in western Alaska.

(C) 2002 Elsevier Science B.V. All rights reserved.
\end{abstract}

Keywords: folding; extension tectonics; rifting; shear zones; physical models; granulite facies; amphibolite facies

\section{Introduction}

The earliest models for the formation of folds

${ }^{*}$ Corresponding author. Tel.: +61-8-9381-2085; fax: $+61-8-$ 9380-1037.

E-mail address: 1harris@tsrc.uwa.edu.au (L.B. Harris). considered that all folds are formed during regional crustal shortening (see historical summary by Carey, 1988, pp. 206-208). Before modern tectonic models 
were established, authors such as van Bemmelen (1955) and Belousov (1965), however, questioned the concept that folding necessitated regional horizontal contraction during compression of the Earth's crust. Alternative conceptual models for folding during horizontal crustal extension (see criteria outlined by Wheeler and Butler, 1994) were also proposed by Carey $(1976,1988)$. Many previous models for folding during crustal extension arose from studies of sedimentary basins and upper crustal levels in orogenic belts. For example, folding accompanying displacement on normal faults has been recognised as an important fold mechanism in extensional terrains such as the Basin and Range Province (Janecke et al., 1998). Folds in the Himalayas and Betic Cordillera formed during collapse and/or gravity spreading were described by Platt (1982), Caby et al. (1983), Burg et al. (1996) and Orozco et al. (1998). Despite these and similar studies, and advances in our understanding of fold mechanisms, folds are still often thought to be rare in extensional tectonic settings (Janecke et al., 1998). Indeed, with the exception of folds associated with pinch-and-swell structures and boudins, Johnson and Fletcher (1994) omit folding during layer-parallel extension from their review of fold mechanisms.

This paper aims at summarising mechanisms for folding during bulk extension of the middle to lower crust. Examples from field studies and analogue modelling are presented to illustrate styles and mechanisms of folds that may develop in high-grade rocks in extensional tectonic settings. Fold mechanisms developed in sedimentary basins and low-grade rocks for folding during horizontal extension are also applied to high-grade rocks. We aim to highlight the possibility for alternative tectonic interpretations to be made from detailed studies of folds in granulite and amphibolite facies terrains. It will be demonstrated that many folds developed in extensional tectonic settings resemble structures produced by regional shortening, hence other criteria (such as pressuretemperature-time paths derived from detailed metamorphic studies) must be used in determining tectonic settings. Fold mechanisms unique to or of particular importance in extensional settings are identified. We also consider models for the origin of shallowly dipping to horizontal foliations and review tectonic environments in which sub-horizontal crustal extension is likely to occur in high-grade rocks.

\section{Tectonic processes resulting in regional extension in high-grade rocks}

\subsection{Rifting}

End-member models for rifting either comprise a continuous extensional shear zone (along which brittle deformation in the upper crust changes progressively to ductile shearing with depth, as in Fig. 1a) or decoupling of discrete faults and/or shear zones by zones of ductile flow (Fig. 2). Ductile flow in the middle to lower crust has been recognised as an important deformation mechanism during rifting (Wernicke, 1990; Ranalli, 1997; Westaway, 1998; Gartrell, 2000; see Fig. 2 for examples). Numerical modelling suggests that flow can also be important in the lower part of the upper crust (Bertotti et al., 2000) and that the geometry of extensional structures varies with the viscosity of ductile layers (that may flow and/ or boudinage) underlying brittle layers (Moresi, 1999a). A zone of ductile deformation may separate and laterally offset displacement along discrete faults in the upper crust and upper mantle, as proposed for the North Viking Graben by Brun and Tron (1993; Fig. 1a). Ductile crustal flow has also been documented during orogenic collapse (Malavieille, 1997; Koyi et al., 1999; Section 2.2). It will be illustrated below that regional scale recumbent folds can develop in zones of ductile flow. Kusznir and Matthews (1988) and Reston (1990) interpret the reflectivity of the lower crust to represent sub-horizontal high-strain ductile shear zones wrapping low strain lozenges. Folds may also form within and adjacent to such shallowly dipping shear zones, and are hence preserved in exhumed high-grade rocks.

The isostatic response to lithospheric extension during rifting results in doming of the asthenosphere and progressive rotation and exhumation of the lithospheric mantle (Fig. 2). This occurs irrespective of whether there is a through-going shear zone from the upper crust to mantle (as in simple shear models of Wernicke, 1985 and Lister et al., 1986) or in modified models that incorporate lower crustal flow (such as discussed by Brun and Tron, 1993; Fig. 2a). Where the crust deforms by distributed ductile flow, broad shear zones develop on either side of the uplifted lithospheric mantle (Fig. 2c-d). Isostatic uplift results in folding of discrete, continuous shear zones devel- 
(a)
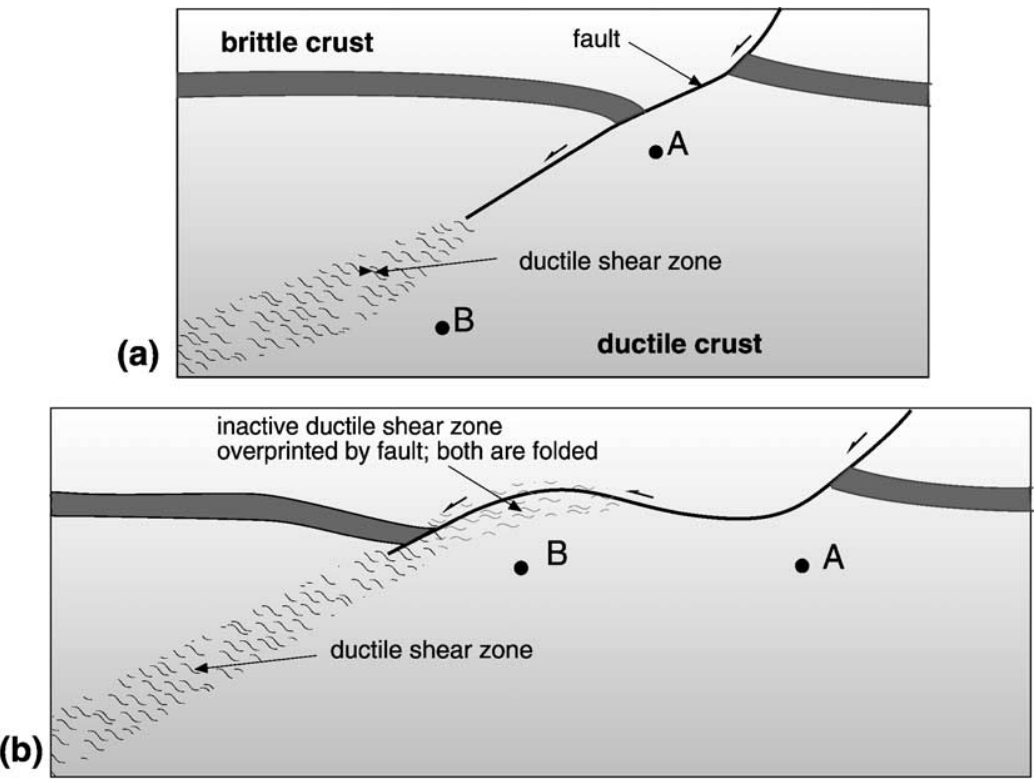

Fig. 1. Schematic cross sections portraying the rolling hinge model for folding of extensional shear zones and exhumation of medium to high grade rocks during asymmetric rifting (after Fletcher et al., 1995). (a) A discrete normal fault in the upper, brittle crust widens into a ductile shear zone with depth. (b) With further horizontal extension and resulting lithospheric thinning, the ductile shear zone in (a) is bowed upward due to isostatic readjustments. This is accompanied by brittle-ductile to brittle overprinting of older ductile fabrics during exhumation. Point B, initially at a much greater depth than point $\mathrm{A}$ in (a) is exhumed to the same depth as $\mathrm{A}$.

oped in earlier stages of rifting (Fig. 1b). Rocks in the ductile crust may be exhumed and overprinted by more brittle fabrics in this process. Structures developed in the uniformly dipping extensional shear zone in Fig. 1a may be reoriented and their dip reversed leading to a local, reverse sense of displacement on limbs dipping opposite to the initial dip of the shear zone (Fig. 1b). It will be illustrated below that a range of fold styles can form within and above extensional shear zones that develop in rift settings. Early-formed folds are refolded during isostatic readjustments during crustal thinning. The sense of displacement on shear zones may therefore be locally reversed in this process leading to potential problems in the interpretation of structures in high-grade rocks.

\subsection{Collapse of a thrust-thickened orogen}

Structures formed in low- to medium-grade rocks during the collapse of thrust-thickened orogens have been described by Dewey (1988), England and Houseman (1989), Mezger et al. (1991), Burchfiel et al. (1992), Gamond (1994) and Davis et al. (1994). Alsop
(1991) describes the collapse of a transpressional orogen. The maximum horizontal extension direction during orogenic collapse may be sub-parallel (e.g. Betic Cordillera, Dewey, 1988; Andes, Dalmayrac and Molnar, 1981; Himalaya, Burchfiel et al., 1992; south Scandinavian Caledonides, Fossen, 1992, 2000), perpendicular (e.g. Tibetan plateau, Dewey, 1988) or oblique (Central Andes, Dewey, 1988) to the direction of initial convergence across the orogen. Selverstone (1988) and Sawyer and Barnes (1994) describe cases where normal displacements are interpreted synchronously on structures striking at a high angle to each other, suggesting local variations in the maximum extension direction. Because of such variations in strain patterns, axes of folds formed during orogenic collapse may therefore be sub-parallel or oblique to those formed during previous crustal shortening. Different orogens may record various stages from collision to orogenic collapse, and along-strike changes between these stages may also occur in a single orogen (Huang et al., 2000).

Late- to post-orogenic extension has also been documented in amphibolite to granulite facies terrains, 


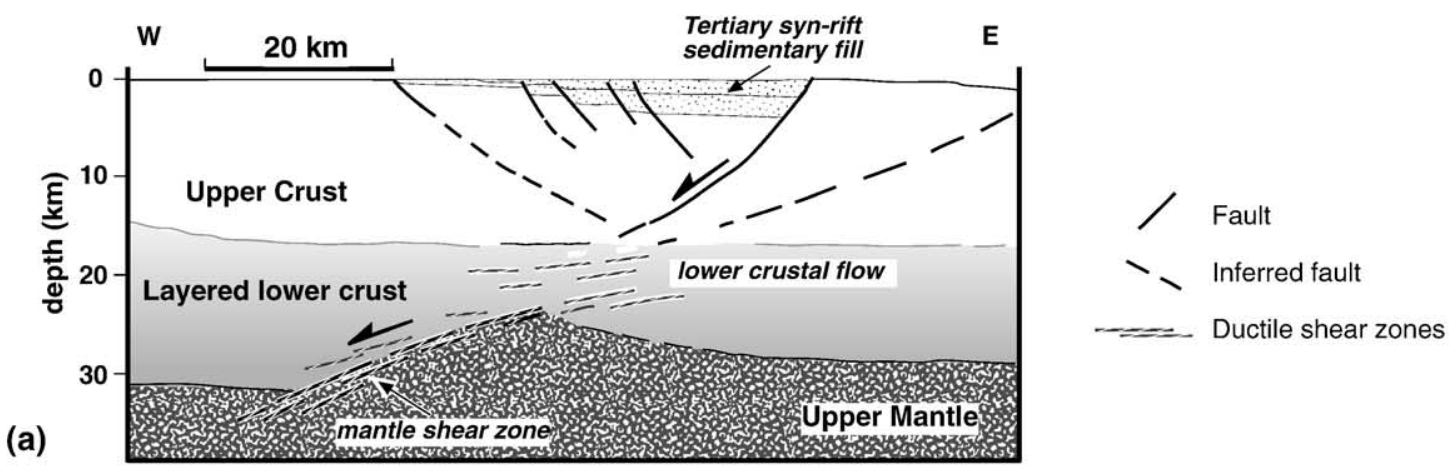

(b)

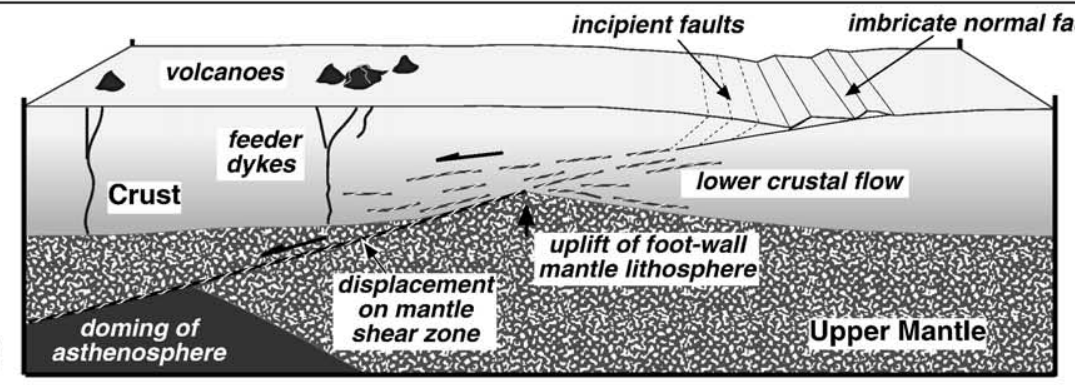

(c)
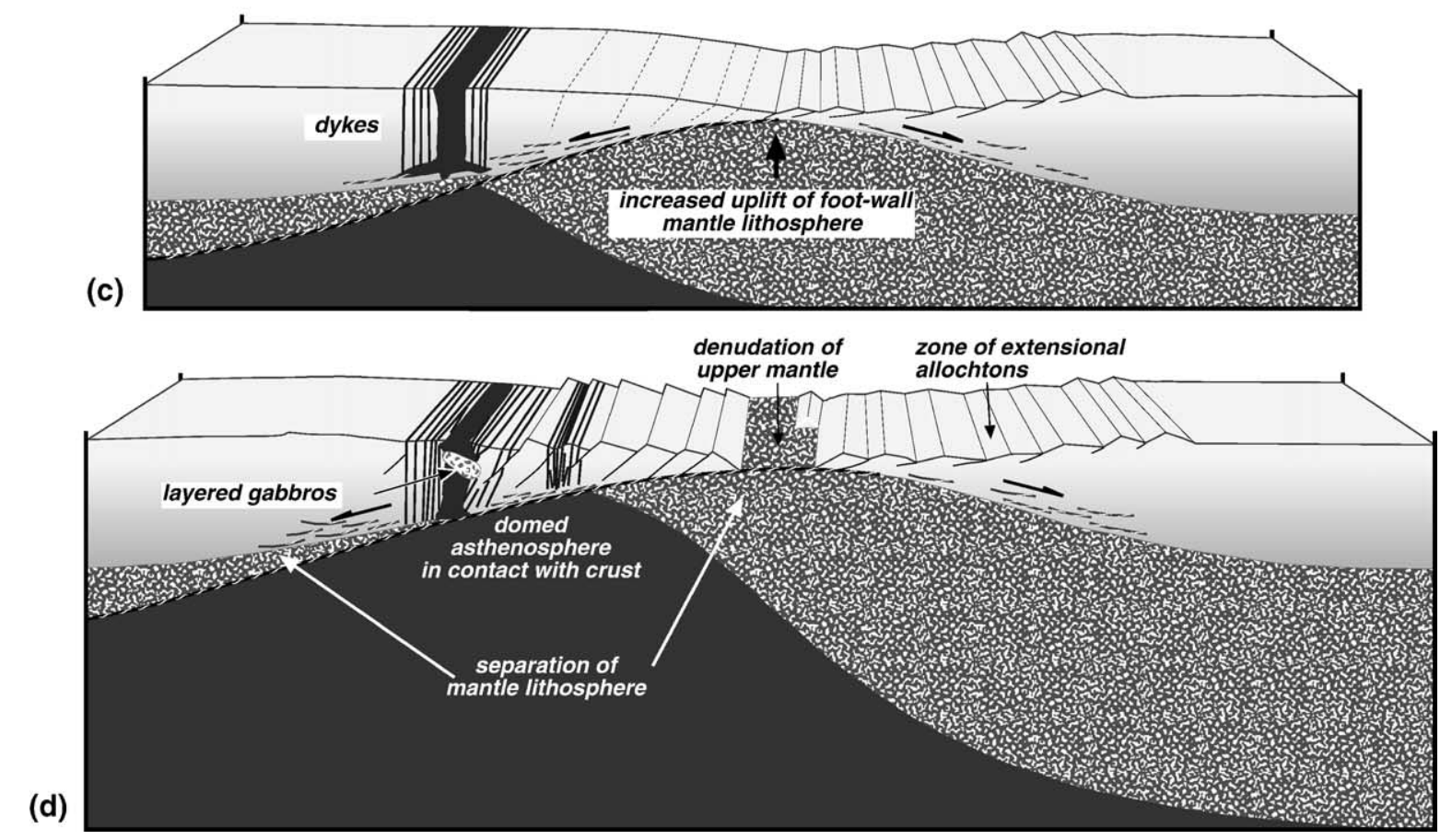

Fig. 2. Flow in the middle- to lower-crust during lithospheric extension in asymmetric rifts. (a) Interpreted section across the North Viking Graben after Brun and Tron (1993). Normal displacement of the upper mantle and asymmetric rifting in the upper crust are separated by a zone of lower crustal flow. (b-d) Progressive development of an asymmetric rift. Reinterpretation of figures from Voggenreiter et al. (1988); the original through-going, Wernicke (1985)-style, lithospheric-scale shear zone in the figures of Voggenreiter et al. (1988) has been replaced by zones of lower crustal flow. 
for example the Western Gneiss Region of Norway (Andersen et al., 1994; Milnes, 1997; Andersen, 1998), Grenville Province (Culshaw et al., 1994, 1997) and northern China (Jiasheng et al., 1994). Late orogenic extension in high-grade terrains (and possibly the accompanying formation of sedimentary basins) may be produced by lithospheric detachment (by convective removal, Fig. $3 a-b)$ or delamination (i.e. "peeling away") of a thickened root or thermal boundary layer (Sandiford, 1989; Nelson, 1992; Docherty and Banda, 1995; Burg and Ford, 1997). The process of delamination has been modelled numerically (Schott et al., 2000) and the results used to provide animations (Schott, 2001). Fig. 3a-b show schematically how a lithospheric root (such as formed during continental collision) may detach and sink into the asthenosphere.

Even after convective detachment of the base of the lithosphere, or if the lower crust has not been delaminated along with the lithospheric mantle (see Kay and Mahlburg, 1993), a thickened crustal root may be present beneath an orogenic belt. If the lower crust comprising the root is less dense than the underlying mantle lithosphere, the root may be isostatically (gravitationally) unstable. The crustal root (Fig. 3c) may then rebound, resulting in lateral spreading of the root material within the lower crust (Milnes et al., 1997; Koyi et al., 1999; Milnes and Koyi, 2000), as illustrated in Fig. 3d. This process occurs in a similar manner to lateral gravity spreading at upper levels of over-thickened crust (e.g. Burg et al., 1984; Burchfiel and Royden, 1985; Dewey, 1988). Rebound of a crustal root results in vertical shortening of the lower crust above the initial root and ductile flow and horizontal shearing of the ductile crust on either side of it (Koyi et al., 1999; Fig. 3c-d). This process can be regarded as "upward gravity spreading" (Koyi et al., 1999). Folding of steeply dipping layering and development of horizontal flattening fabrics is likely to occur in high-grade rocks above the centre of root uplift (Fig. 3d). Recumbent folds, along with inclined shear and flattening foliations, are likely to develop in the shear zones on either side of the area of root rebound.

Delamination of the lithospheric mantle following subduction of oceanic crust and continent-continent collision may result in widespread crustal extension, lithospheric thinning and increased magmatism (Kay and Mahlburg, 1991, 1993; Malavieille, 1997; Fig. 3e-g). A-type subduction (Bradbury and Nolen-Hoeksema, 1985; Etheridge et al., 1987), a similar process except that there has not been previous subduction of oceanic crust, has also been proposed for regional extension and basin formation in some Archaean and Proterozoic terrains. Under high-grade metamorphic conditions, folds and foliations formed during crustal thickening may be overprinted or even obliterated by structures formed during the ensuing extension.

Finite element modelling by Govers and Wortel (1993) shows that the development of detachment faults is likely in the transition zone of continental lithosphere where normal shearing occurs along a dipping zone of localised deformation in the lower crust. This occurs when continental lithosphere has been rapidly thickened and where a change to a tensional regime has also taken place in a short time period (Govers and Wortel, 1993). Their modelling shows that at the end of a contractional phase of continental thickening, mantle delamination is a likely mechanism for initiating detachment faults at lower crustal levels. Mareschal (1994) has shown that homogeneous lithospheric thickening would not lead to post-orogenic extension unless special conditions were met and with the lithosphere being hotter than normal. Rapid removal of the mantle lithosphere by delamination would, according to Mareschal (1994), increase the tensile stress, rapidly heat the lithosphere, reduce its strength and always trigger extension. An example of post-collisional radiogenic heating, removal of lithospheric mantle below the orogenic crust, followed by rapid stretching (based on modelling the calculated $P-T$ path) is given by Platt et al. (1998) for high-grade metamorphic rocks drilled by the Ocean Drilling Program in the Alboran Sea.

\subsection{Extension related to granitoid intrusion}

Partial melting of the lower crust to form granitoids may occur due to heating by a mantle plume, in a subduction environment due to dehydration in the descending slab, or after delamination of cold lithosphere in a collisional setting (Moresi et al., 2000). Crustal deformation during the ascent of a hot (1000 ${ }^{\circ} \mathrm{C}$ ), inherently buoyant blob of low viscosity material at a depth of ca. $25 \mathrm{~km}$ in the crust (representing granitoid derived from melting of the lower crust by an underlying heat source) has been modelled numeri- 
cally by Moresi et al. (1998, 2000). Modelling shows that when the crust has a high yield stress, the granitoid rises as a viscous diapir in the lowermost crust and may spread laterally when it encounters a density interface. The granitoid then continues to rise as a series of smaller bodies. A single diapir developed in models where the crust had a low yield stress. Models show that the diapiric rise of granitoids results in sub-horizontal extension and local entrainment of the lower crust. Normal displacement occurs along

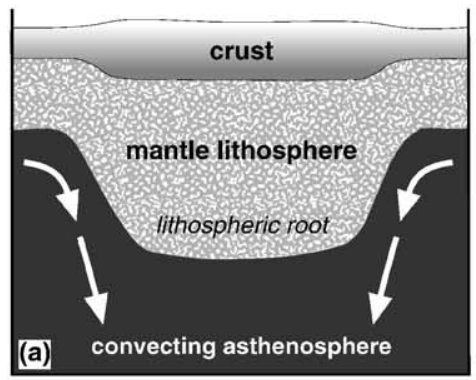

undeformed grid
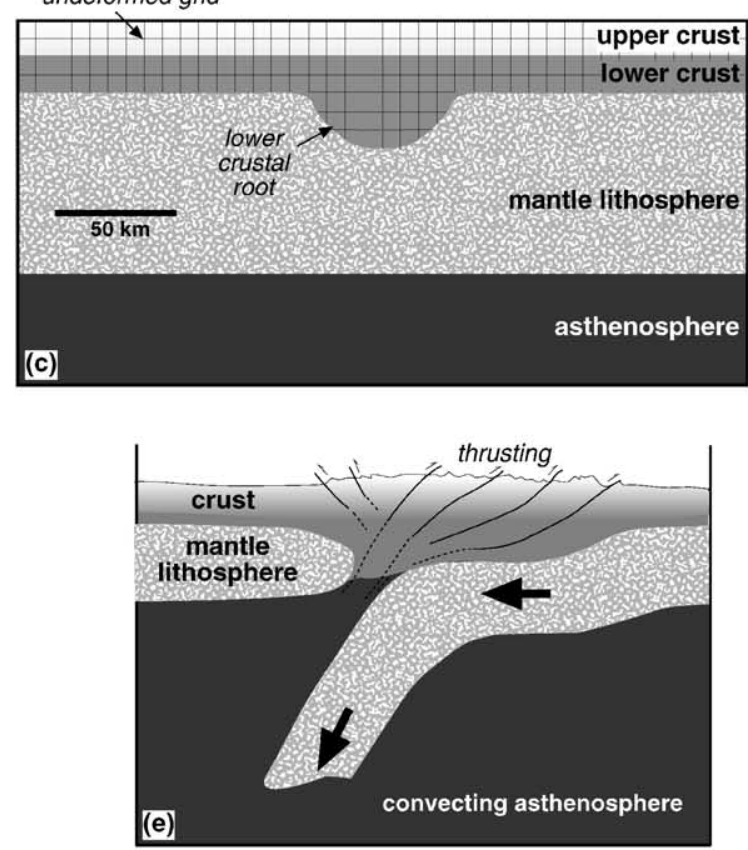
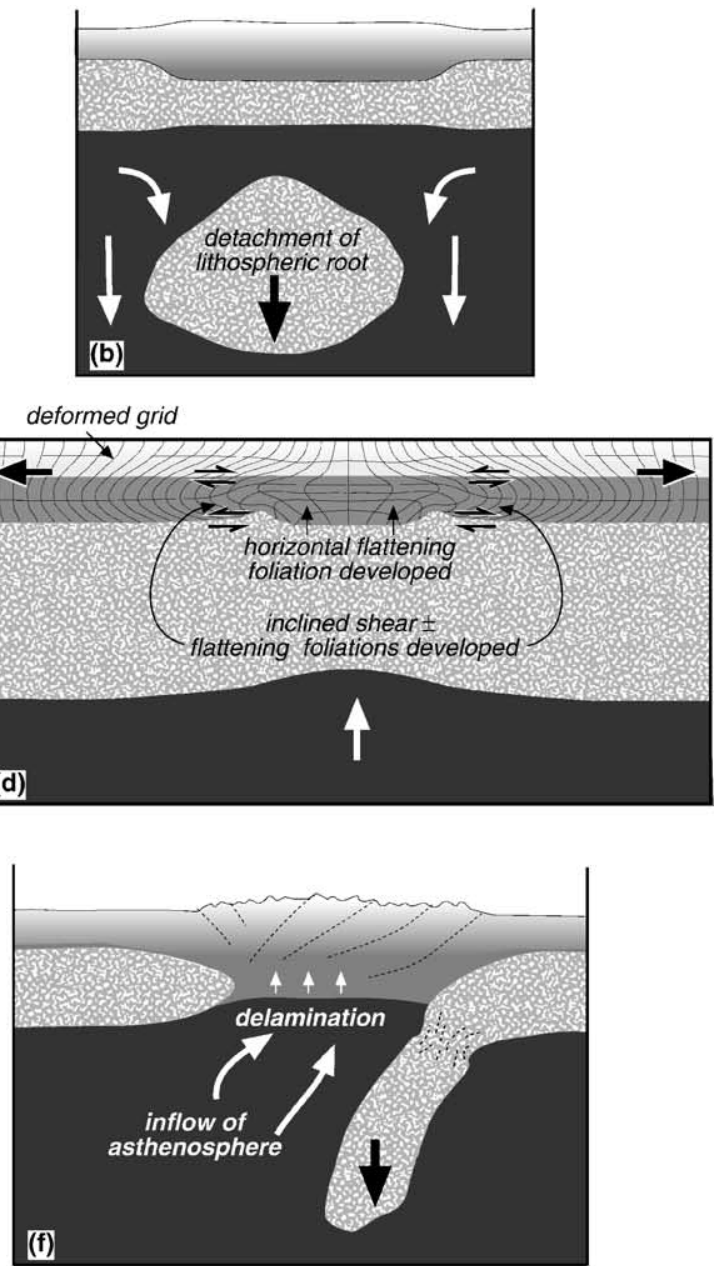

(f)

MCC extensional faulting

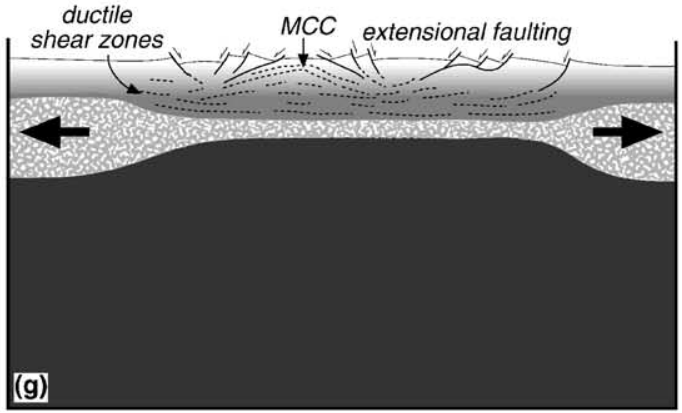


pre-existing discontinuities in the middle and upper crust (model 2 of Moresi, 1999b).

\subsection{Extension contemporaneous with thrusting in orogenic belts}

Extension may also locally occur contemporaneous with, and parallel to, the direction of regional bulk shortening in an orogenic belt (e.g. Platt, 1986; Malavieille, 1997; Jolivet and Goffé, 2000). Extensional structures formed both during and following regional contraction can coexist along the same cross section of an orogen (Jolivet and Goffé, 2000). For example, the local formation of normal shear zones striking parallel to thrusts has been described in the Himalayas by Burg et al. (1984), Burchfiel and Royden (1985), England and Houseman (1989) and Burchfiel et al. (1992). Normal shear zones may also develop striking perpendicular to the trend of an orogen during orogen-parallel extension in a regional convergent tectonic setting, such as in the Cycladic blueschist belt in the Aegean Sea (Avigad and Garfunkel, 1991), southern Apennines (Oldow et al., 1993), Alpine-Carpathian-Pannonian system (Decker and Peresson, 1996) and Québec Grenville Province (Harris et al., 2001). Normal shear zones striking perpendicular to the orogen may cut earlier orogen-parallel detachments, as in the North China granulite terrain (Jiasheng et al., 1994).

The development of conjugate transcurrent shear zones at a convergent margin is a common response after initial thrusting. This represents a change from vertical extension during thrusting to orogen-parallel extension and lateral escape (Molnar and Tapponnier, 1977; Decker and Peresson, 1996). Areas of extension may alternate with areas of contraction during block rotation between transcurrent faults at an arcuate margin (Garfunkel and Ron, 1985; Geist et al., 1988). Local contractional or extensional sites also form due to changes in strike or en relais stepping of transcurrent ductile shear zones in the deep crust (similar to brittle-ductile shear zones reviewed by Sylvester, 1988).

\section{Origin of shallowly dipping foliations in high- grade gneiss terrains}

Before considering mechanisms for folding during horizontal extension of granulite and amphibolite facies terrains, the timing and tectonic environment in which sub-horizontal metamorphic foliations may form will be briefly examined. It is easy to visualise how a foliation that formed with a steep dip is developed during bulk sub-horizontal shortening. The formation of sub-horizontal foliations is, however, more problematic. Conceptual models for the development of shallowly dipping foliations in highgrade rocks in both contractional and extensional tectonic settings have been proposed. For example, flat-lying foliations in the Himalayas (Mattauer, 1975) and shallowly dipping, high-grade compositional layering in Sri Lanka (Kröner et al., 1994) were interpreted as resulting from a combination of flattening and noncoaxial deformation during thrusting. Alternatively, Sandiford (1989) and Andersen and Jamtveit (1990) suggest that sub-horizontal flattening foliations in granulite facies terrains (especially those that record peak metamorphic conditions) may have developed as a result of vertical shortening during orogenic collapse after crustal thickening. In this situation, early thrust-related fabrics may be obliterated (Sandiford, 1989). Some early fabrics may, however, be locally preserved in more mafic lithologies where recrystallisation may be less complete (see Passchier et al., 1990, Chapter 4, for a discussion on "memory destruction" in high-grade rocks).

Fig. 3. Mechanisms for late- to post-orogenic extension. (a-b) Convective detachment of a lithospheric root, after Burg and Ford (1997). (c-d) Upward gravity spreading model based on numerical models of Koyi et al. (1999). An initially square grid superposed on crustal layers (c) is deformed during rebound of the lower crustal root (d). Deformation of the grid implies vertical shortening above the former root. Horizontal foliations are likely to develop in this region in nature, whereas recumbent folds and inclined shear and flattening fabrics may develop in the zone of ductile flow in the lower crust on either side of the area of root rebound. (e-g) Delamination and eventual crustal extension following crustal thickening at a collisional orogen (after Malavieille, 1997). (e) Thrust thickened crust at end of continent-continent collision. (f) Delamination of mantle lithosphere of the subducting slab. The delaminated slab sinks into the lithosphere and may eventually break off. Inflow of hot asthenosphere results in high temperature metamorphism and weakening of the thickened lower crust. (g) Widespread post-orogenic extension results in flow and formation of horizontal flattening and shallowly dipping shear fabrics in the ductile crust, and detachment faulting in the upper crust. High-grade rocks may be exhumed in metamorphic core complexes (MCC). 
Studies of metamorphic core complexes (e.g. Malavieille, 1987a,b; Coney, 1980; Hill et al., 1992) show that shallowly dipping gneissic foliations may develop during crustal extension. In such settings, shear fabrics along extensional detachments may overprint subhorizontal flattening foliations (e.g. Andersen et al.,
1994) and/or develop within zones of pervasive flow in the ductile crust (e.g. Brun and Van Den Driessche, 1994). Folding of upright folds and/or steeply dipping foliations (developed during previous horizontal shortening) by folds with sub-horizontal axial surfaces and crenulation cleavage may occur from vertical short- (a)

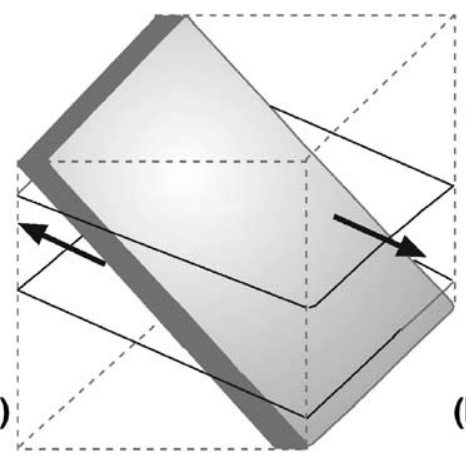

(b)
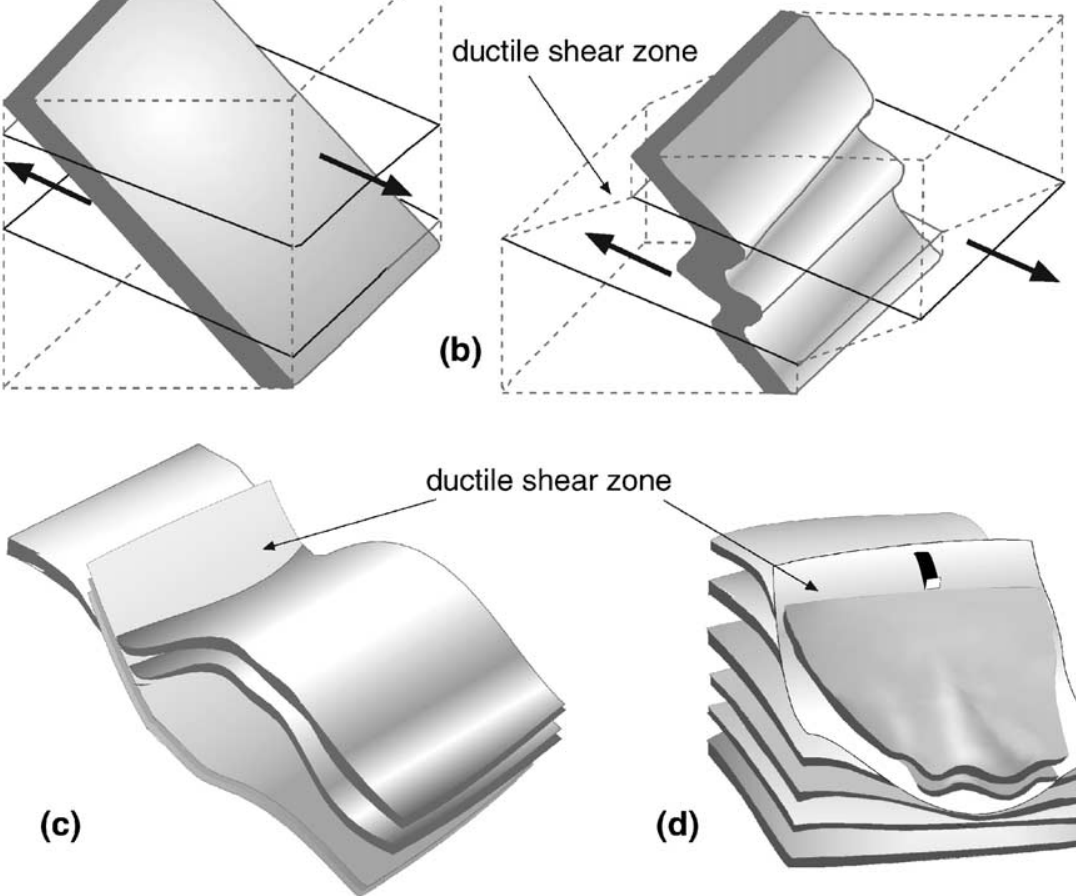

(d)

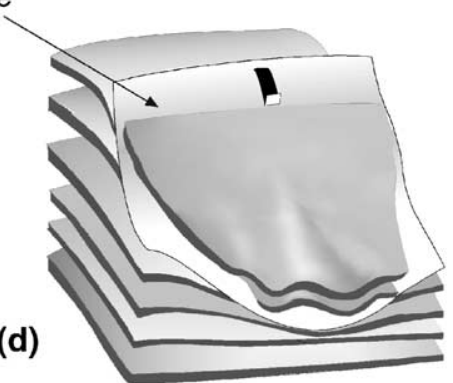

(e)

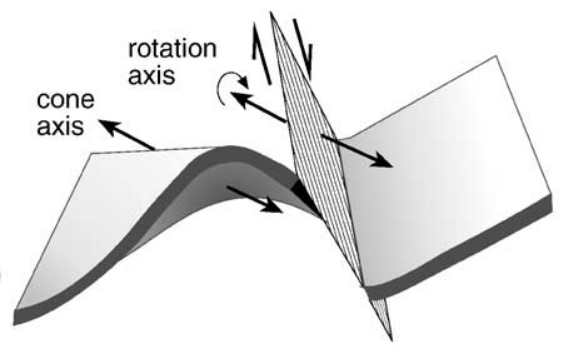

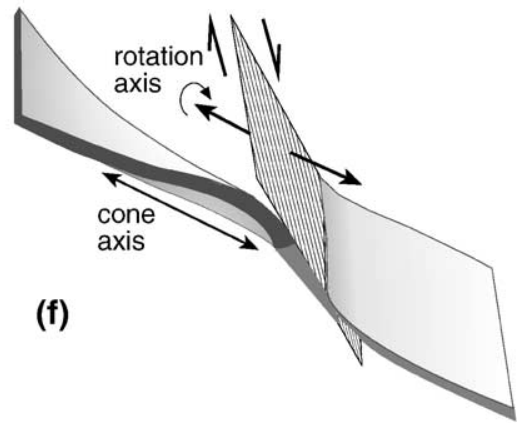

Fig. 4. Folds formed during displacement on a single extensional ductile shear zone. $(a-b)$ Folding in a broad normal ductile shear zone where layering dips steeper than the shear zone (after Froitzheim, 1992). (c) Folding above a listric normal shear zone of constant strike with a rampflat geometry. Folds form with axes trending sub-parallel to strike of the shear zone. (d) Folding above a 'spoon-shaped' normal shear zone. Conical folds form with axes trending sub-parallel to the maximum extension direction (at high angle to the strike of the shear zone). (e-f) Conical drag folds formed by passive rotation of tilted layers during oblique-slip displacement (after Becker, 1995). In (e), the layer originally dips in the opposite direction to shear zone whereas in (f), the layer has a shallower dip, but in the same direction as the shear zone. 
ening during the processes of late orogenic extension outlined in Section 2.2. The progressive development of a horizontal transposed foliation due to gravitydriven flattening is illustrated by Dirks et al. (1997, fig. 6). Such structures have been described from the Pyrenees (Aerden, 1994), Apennines (Carosi et al., 1996), North China Craton (Dirks et al., 1997) and Québec Grenville Province (Harris et al., 2001). As noted in Section 2.2, vertical shortening and horizontal extension during root rebound and upward gravity spreading may also produce horizontal and shallowly dipping tectonic foliations in deep crustal rocks.

\section{Folding associated with discrete extensional shear zones}

\subsection{Folding where layering dips steeper than an extensional shear zone}

Froitzheim (1992) shows that folds may develop in an extensional setting when dipping strata are cut by a shallower dipping normal shear zone (Fig. 4a-b). Fold axes initiate sub-parallel to the line of intersection between the shear plane and the layering, which is generally sub-perpendicular to the shear direction. Fold vergence is consistent with the normal sense of displacement (in comparison to folds described in Sections 5.2 and 6 below).

\subsection{Folds developed above normal shear zones}

Seismic images of the upper crust commonly portray rollover antiforms resulting from collapse of the hanging wall above listric normal faults and broad synforms developing above fault ramps (e.g. Dula, 1991 and references cited therein; Fig. 4c). Such rollover or fault-bend folds have been created in sandbox experiments (e.g. Cooke and Harris, 1987; Ellis and McClay, 1988; McClay, 1989) and modelled kinematically (Braun et al., 1994). The style of folds above a listric normal fault may vary significantly (Fig. 5) depending on the amount of fault drag (Braun et al., 1994). Folding above fault-parallel and fault-perpendicular bends in normal faults is common in the Rocky Mountain Basin and Range province (Janecke et al., 1998). In the examples described by Janecke et al. (1998), whilst most folds were open and strata upright
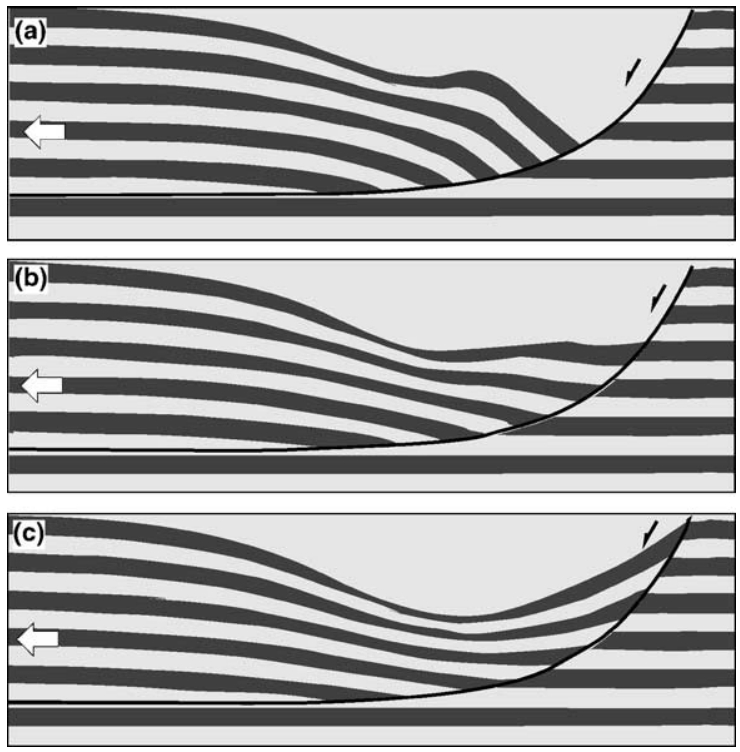

Fig. 5. Results of kinematic modelling of deformation above a listric normal fault with varying degrees of fault drag (modified after Braun et al., 1994, Fig. 11). (a) No friction on fault plane (displacement on tip of hanging wall, $u_{\mathrm{t}}=$ displacement of hanging wall far away from fault tip, $\left.u_{\mathrm{o}}\right)$; (b) friction along fault plane $\left(u_{\mathrm{t}}=u_{\mathrm{o}} / 2\right)$; (c) fault locked $\left(u_{\mathrm{t}}=0\right)$. Note that similar fold geometries occur above listric normal shear zones in high-grade rocks.

facing, two extensional folds were noted that locally overturn strata. Folding may be enhanced by the presence of a ductile substrate. For example, in sedimentary basins, salt can accommodate block rotations of overlying sedimentary strata (Fig. 6a), as described by Duval et al. (1992) and Weijermars et al. (1993).

Folds formed due to rollover onto listric normal faults in low-grade sedimentary strata have sometimes been misinterpreted as being due to horizontal shortening (as noted by Janecke et al., 1998 and Seyitoğlu et al., 2000). This may also be the case in high-grade terrains where folds with comparable geometries develop above listric normal ductile shear zones. In high-grade gneiss, ductile and less dense horizons (e.g. syn-tectonic granites or pegmatites) may aid rollover on shear zones and rise diapirically in the same manner as salt in the upper crust, as shown in Fig. 6a. When little or no melt or fluids are present (as in anhydrous granulites), folds similar to those shown in Fig. $5 b-c$ are likely to form above listric extensional shear zones. A broad synform may develop in high-grade rocks (as seen in all models in Fig. 5) 
(a)

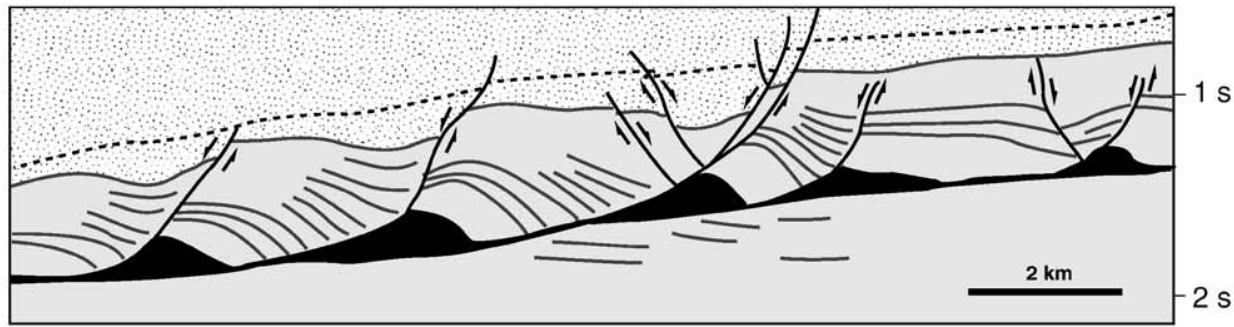

(b)

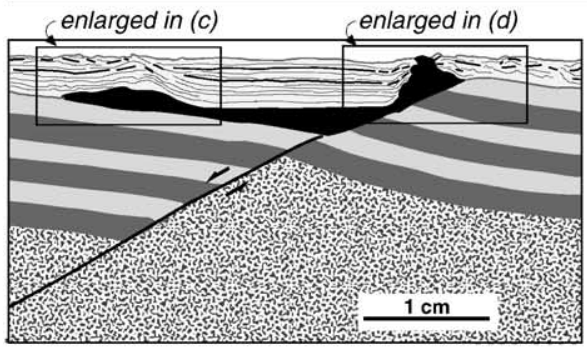

(c)

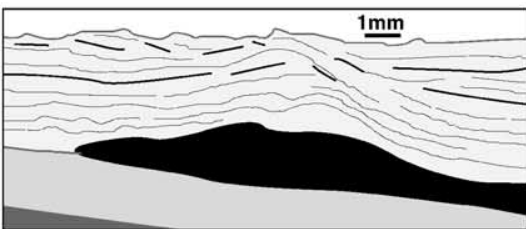

(e)

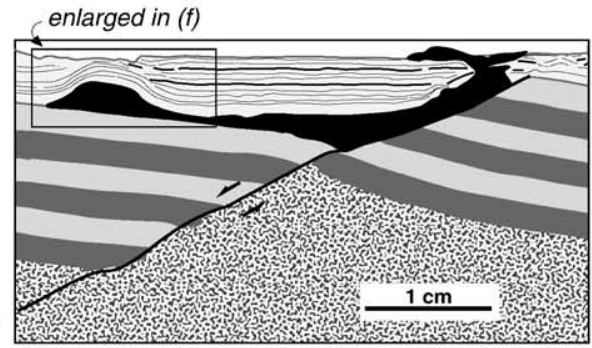

(d)

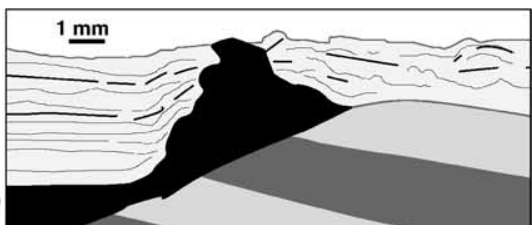

(f)
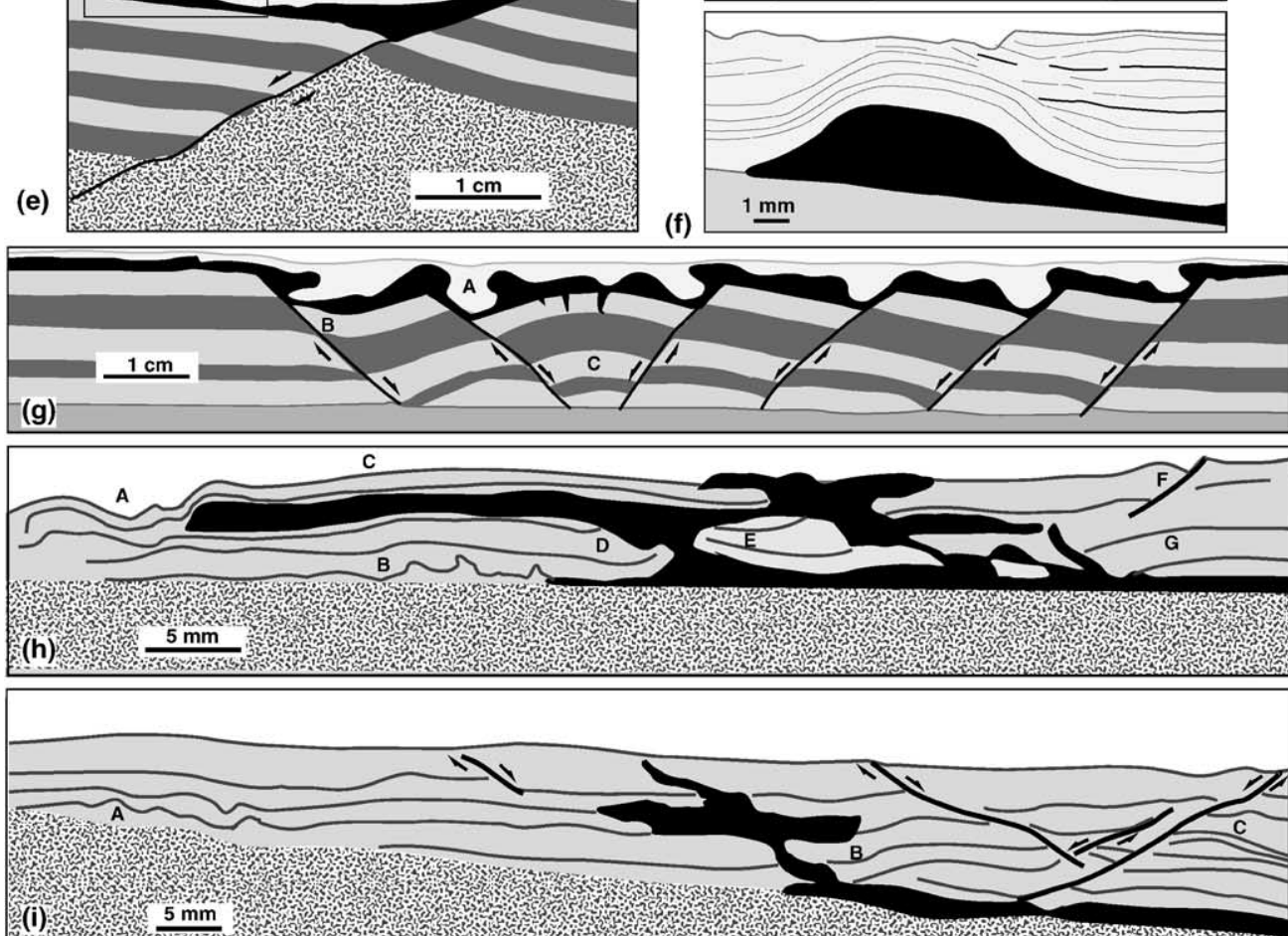

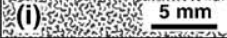

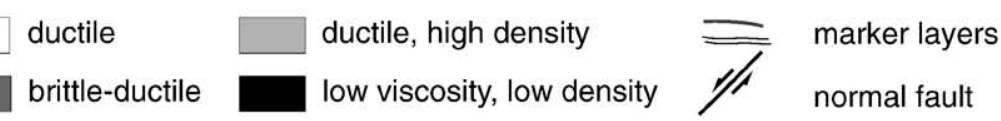

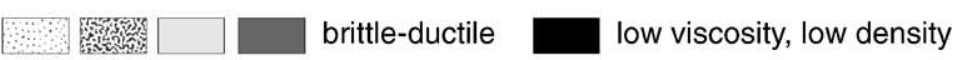

normal fault 
instead of a crestal graben commonly observed in low-grade sedimentary strata above listric faults and developed in sandbox models (Cooke and Harris, 1987; McClay, 1989). The footwall strata in sandbox models of listric normal faulting and in examples from sedimentary basins are generally undeformed. Ductile drag of footwall layers into normal shear zones, however, frequently occurs in high-grade rocks.

Folds above listric normal shear zones of constant strike initiate with axes sub-parallel to the strike of the shear zone (Fig. 4c). Axes of minor folds may undergo rotation towards parallelism to the displacement direction if strain is high (as described in Section 5.2). When there is an increase in along-strike curvature of a listric shear zone with depth, a "spoon-shaped" shear geometry is produced (Fig. 4d). During displacement on a spoon-shaped extensional shear zone, constrictional strains result in layers undergoing contraction at a high angle to the displacement direction. The resulting folds in the hanging-wall layers are typically conical, with axes at a large angle to the average strike of the detachment. Becker (1995) shows that conical folds may also form by drag of layers dipping in an opposite sense to an oblique-slip shear zone (Fig. 4e) or due to oblique-slip displacement of a shallowly dipping layer (Fig. 4f).

As a result of isostatic asthenospheric uplift during rifting, ductile shear zones and extensional detachments (along with any folds formed within these zones as described above) are progressively folded (Fig. 1b), with fold axes sub-parallel to the strike of the detachment (Fletcher et al., 1995).

\subsection{Extensional forced folds}

In sedimentary basins, extensional forced folds may develop in ductile strata above normal faults that affect more brittle strata. Withjack et al. (1990) note that forced folds are more likely to develop above steeply dipping normal faults and where detachments and/or thick ductile units are present to decouple the folded strata from brittle faulted strata. Extensional forced folds have been modelled experimentally using clay layers (Fig. 7a-b) by Withjack et al. (1990). The results of this modelling are equally applicable to the study of high-grade terrains where faulting of competent layers such as mafic granulite may induce extensional forced folds in overlying ductile layers (e.g. felsic gneiss). An example of minor forced folds from the Øygarden Complex, northeastern Sotra, Norway (described in Section 9.1) is given in Fig. 7d. Similar structures may form at the metre and regional scales. Detachments between gneissic layers and between ductile and brittle horizons may produce monoclinal structures in high-grade rocks comparable to those described by Withjack et al. (1990) from shallower crustal levels in the Gulf of Suez (Fig. 7c).

\subsection{Diapirs and related structures}

Ramberg (1973) has shown that folds may develop in the upper surface of layers overlain by denser material with either one or two dominant wavelengths. If the density contrast is great, the lower, less dense material may rise vertically or obliquely along ductile

Fig. 6. Diapiric mobilisation of a buoyant ductile layer within denser overlying ductile layers during horizontal extension. (a) Interpretation of migrated seismic reflection profile from the Kwanza Basin, Angola (modified after Duval et al., 1992) where the positions of salt diapirs (black) within sedimentary rocks are controlled by normal faults. Diapiric emplacement of salt has aided rollover and rotation of hanging-wall strata. Similar diapiric emplacement of granitoid bodies or pegmatites formed in situ may occur during displacement on normal shear zones in highgrade rocks. $(b-f)$ Centrifuge analogue models (traced from photographs in Koyi, 1996) showing normal fault controls on diapirism. (b) and (e) are early and late stages, respectively, of a model where micro-laminates of alternating plastilina and Dow Corning silicone putty are folded during diapiric mobilisation of a low-density ductile layer above a faulted block. Details of these figures are given in (c-d) and (f) show folding of micro-laminates above, ahead and on the flanks of diapirs. (g) Localisation of diapirs of buoyant Polydimathylsiloxane (SGM36) into denser Rhodorsil gomme above normal faults in semi-brittle plastilina layers simulating basement (redrawn from Koyi, 1991). Similar structures developed in high-grade rocks at the thin-section to outcrop scale may be used as a facing indicator. Note that at A, folds in the interface between mobilised layer and overlying layer show opposed vergence. Folding of semi-brittle layers due to drag along normal shear zone is seen at $\mathrm{B}$ and the formation of a broad antiform between shears of opposed dips at $\mathrm{C}$. ( $\mathrm{h}-\mathrm{i}$ ) Results of centrifuge analogue models (adapted from Koyi et al., 1993). Folds, such as A and B in (h) and A in (i), are formed in micro-laminate layers as a result of lateral and oblique (shearcontrolled) migration of low density-low viscosity (Silbione silicone putty) during gravitational gliding. Folds are also formed due to drag on diapir margins, such as at D and $\mathrm{E}$ in (h) and rollover onto normal shear zones, some of which have been intruded by the low-density material as at $F$ and $G(h)$. Similar structures may form as the result of migration of partial melt or solid-state gravity-driven mobilisation of low-density felsic horizons in high-grade rocks during lower-crustal flow in extensional settings. 
shear zones to form diapiric structures and sheets similar to those developed experimentally (Fig. 6bi). During their upward flow, buoyant materials deform within a diapir and may form complex folds
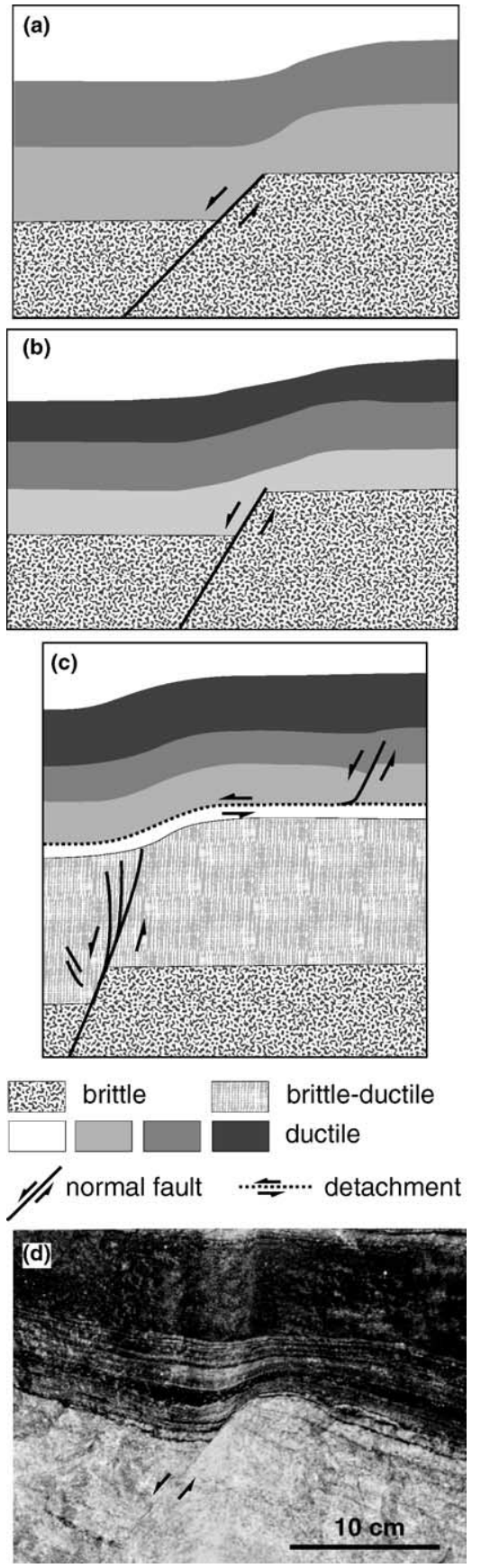
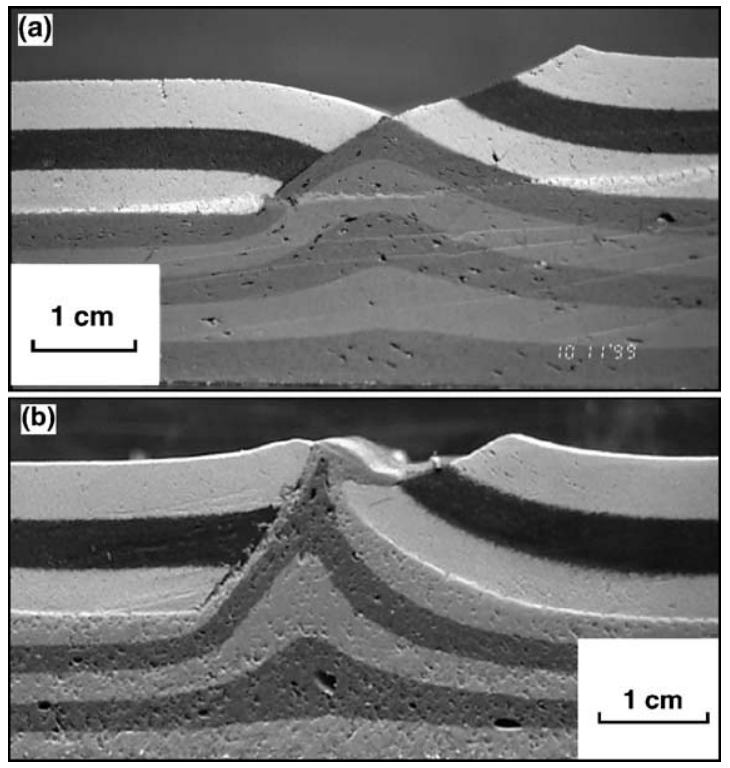

Fig. 8. Model profiles showing examples of folding during extension (after Koyi and Skelton, 2001). (a) Upright folds in lower, denser ductile layers which rise isostatically during rifting of the overlying semi-brittle layers. Note that the folded layers are thickened in the hinge area. The upper, semi-brittle layers are also folded; the hanging wall layers fold as they rollover, whereas the footwall layers are bent upward during the isostatic rise of the lower layers. (b) Upright folds in buoyant lower layers rising diapirically during the rifting of semi-brittle upper layers. Note here also that the folded layers are thickened in the hinge area. Unlike (a), the hanging wall layers do not show any rollover structure. The footwall layers are bent upwards by the rising buoyant layers.

in surrounding layers, as documented by Ramberg $(1967,1981)$. Folds are developed above and on the margins of the diapirs (e.g. Fig. 6c,d,f) and above areas of lateral spreading (e.g. location $\mathrm{C}$ in Fig. 6h).

Pegmatites generated in situ by partial melting in flat-lying migmatitic gneiss may show irregular upper surfaces with more uniform bases as developed in the

Fig. 7. Extensional forced folds. Sketches of clay models $(a-b)$ and schematic cross section of forced folds from the Gulf of Suez (c) modified after Withjack et al. (1990). (a) No slip along contact between ductile layers; dip of fault $=45^{\circ}$, (b) layer-parallel detachments separate ductile layers, dip of fault $=60^{\circ}$. (d) Example of extensional forced folds in ductile layers over faulted semi-brittle unit in amphibolite facies gneiss of the Øygarden Complex from Agotnes, northeastern Sotra, Norway (see Section 9.1). Similar structures may also develop in high-grade rocks at a more regional scale where there are distinct mechanical differences between lithologies. 
low-density material in Fig. 6g. These 'cauliflower structures' may be used as a facing indicator in highgrade metamorphic rocks (Burg, 1991; Burg and Vanderhaeghe, 1993). Pegmatites along extensional detachments may appear highly sheared in sections parallel to the displacement direction whereas cauliflower structures may be observed in sections orthogonal to the displacement direction, as illustrated by Burg (1991). Pegmatites may also show upward and lateral (often shear controlled) migration paths (Burg, 1991), as developed in centrifuge models (Fig. 6h-i). Lateral migration along layers may result in local shortening producing folds (e.g. A and B in Fig. 6h and A in Fig. 6i). Merle and Vendeville (1992) have also modelled comparable folds and thrusts produced without bulk horizontal shortening by lateral flow during igneous intrusion.

Fig. 8 shows two centrifuge models of Koyi and Skelton (2001) in which ductile layers beneath faulted semi-brittle layers are folded during horizontal extension. In Fig. 8a, although the lower ductile layers are denser than the overlying semi-brittle layers, an open, symmetrical anticline (with thickening in fold hinges) is created due to isostatic readjustments. The overlying semi-brittle layers are displaced in a normal sense and show reverse drag along the fault forming a rollover anticline in the hanging wall. Where the ductile layers are less dense than the overlying semibrittle layers, the antiform in ductile layers is tighter, and no rollover of semi-brittle layers onto the fault has (a)

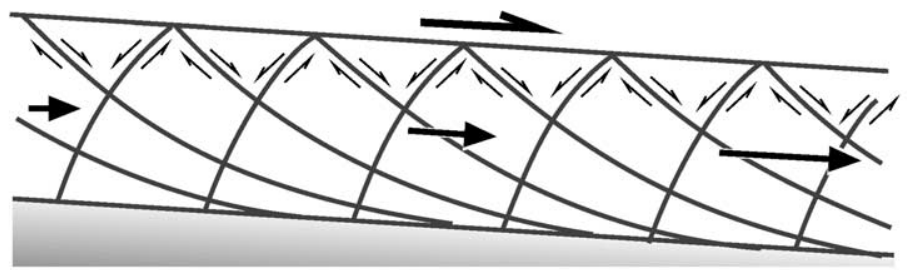

(c)

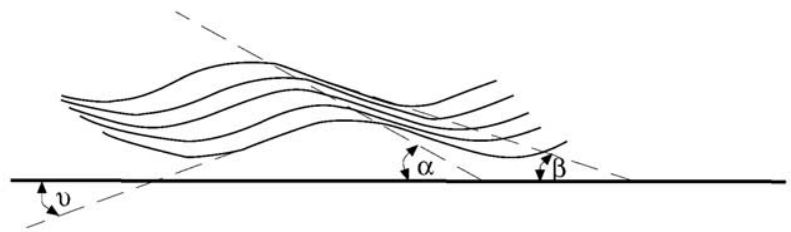

(e)

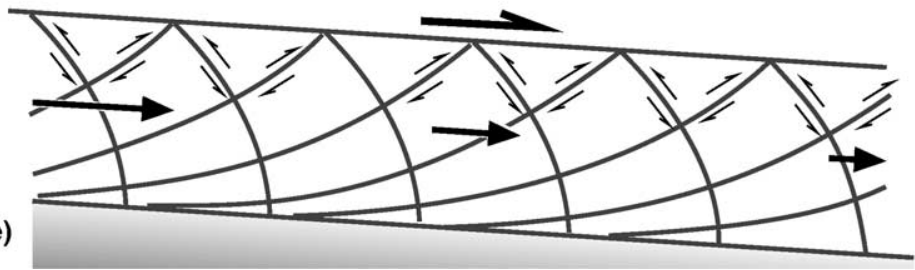

(b)

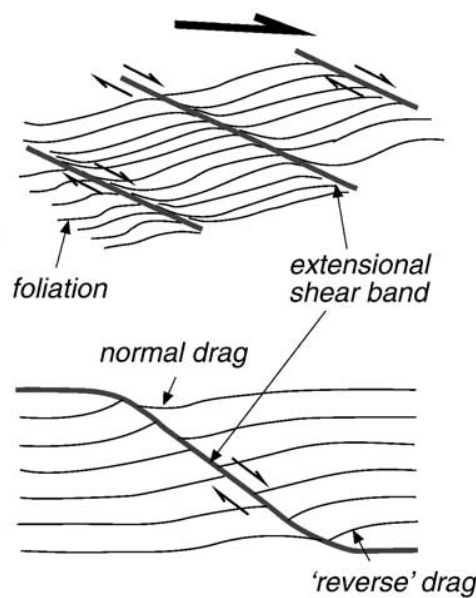

reverse shear band

(f)

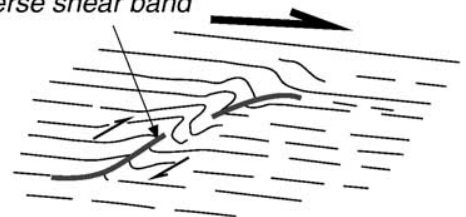

Fig. 9. Subsidiary shears and related folds that may develop in extensional detachments, regions of gravity spreading in the upper crust, and areas of upward gravity spreading in the middle- to lower-crust. (a) Orientation of potential slip lines (lines tangential to the maximum shear stress) within a plastic layer of uniform thickness extending in the direction of gravitationally induced flow. Flow velocity (shown schematically by solid arrows) increases down-slope. (b-d) Extensional shear bands that may form in the orientation of synthetic shears shown in (a). Normal shear may be partitioned into narrow shear bands (normal-slip crenulations) in (b) or into broader zones to form extensional crenulation cleavage as shown in (c). Average angles determined in the study by Platt and Vissers (1980) are $\alpha=29.4^{\circ}, \beta=16.8^{\circ}, v=16.9^{\circ}$. (d) Asymmetric foliation boudinage. Note change from normal to reverse drag along shear band. (e) Orientation of potential slip lines where there is compression in the direction of flow. Flow velocity decreases down-slope. (f) Reverse-slip crenulations (contractional or reverse shear band) that may form in the orientation of the shallower-dipping reverse shears shown in (e). Figures (a) and (e) modified after Lliboutry (1982, Fig. 12.10), (b) and (f) modified after Dennis and Secor (1990) and (c-d) modified after Platt and Vissers (1980). 
occurred (Fig. 8b). In both models, semi-brittle layers in the footwall are bent upwards during the rise of the underlying ductile layers. Structures similar to these may form at diverse scales in horizontally layered gneisses of variable competency and/or density in extensional settings.

\section{Folding within extensional ductile shear zones}

\subsection{Folds associated with secondary shear bands in ductile shear zones}

The predicted orientation of potential slip lines within a shallowly dipping extensional shear zone or zone of gravitational spreading have been shown by Lliboutry (1982, fig. 12.10) to vary depending on whether the flow velocity increases or decreases down-slope. Where the flow velocity increases downslope (i.e. where there is no impediment to flow), moderate to shallowly dipping listric synthetic extensional shears and steeply dipping, antithetic normal shears are predicted (Fig. 9a). In nature, such potential slip surfaces equate to extensional secondary shears/ normal-slip crenulations (Fig. 9b-d). Open, asymmetric folds may develop associated with broad extensional shear bands (Fig. 9c). Foliations may be dragged in either normal or reverse senses at different positions along the same structure during asymmetrical foliation boudinage (Platt and Vissers, 1980), as illustrated in Fig. 9d. Where the flow velocity decreases down-slope (i.e. where there is an impediment to flow), moderate to shallowly up-slope dipping, listric reverse and steeply down-slope dipping reverse potential slip surfaces are predicted (Fig. 9e). In nature, reverse shear bands and related overturned folds develop under such conditions (Fig. 9f).

\subsection{Progressive folding in extensional ductile shear zones}

Layering inclined to shear zone margins (i.e. oblique to the streamlines in the material, Cobbold and Quinquis, 1980) may fold during progressive deformation in extensional detachments in the same manner as described for thrust or transcurrent ductile shear zones (see review by Williams et al., 1994). Outcrop to kilometre-scale folds have been described in exten- sional detachment shear zones in the Apennines (Carmignani et al., 1994) and Caledonides (Fossen and Rykkelid, 1990). Large recumbent fold structures in

(a)

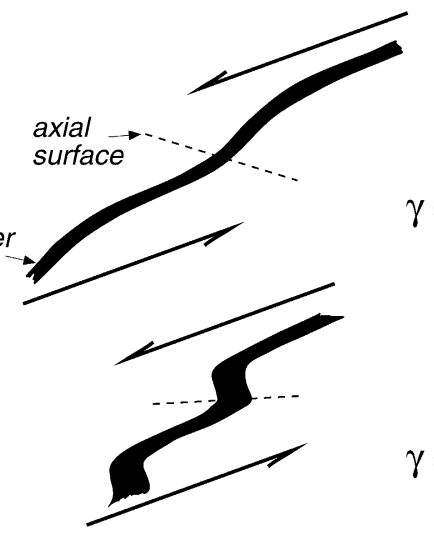

(c)

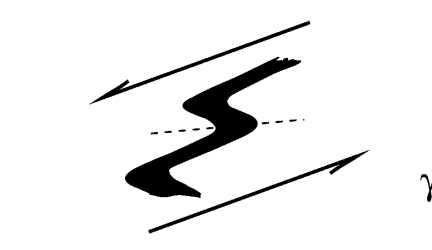
$\gamma=3$

(d)
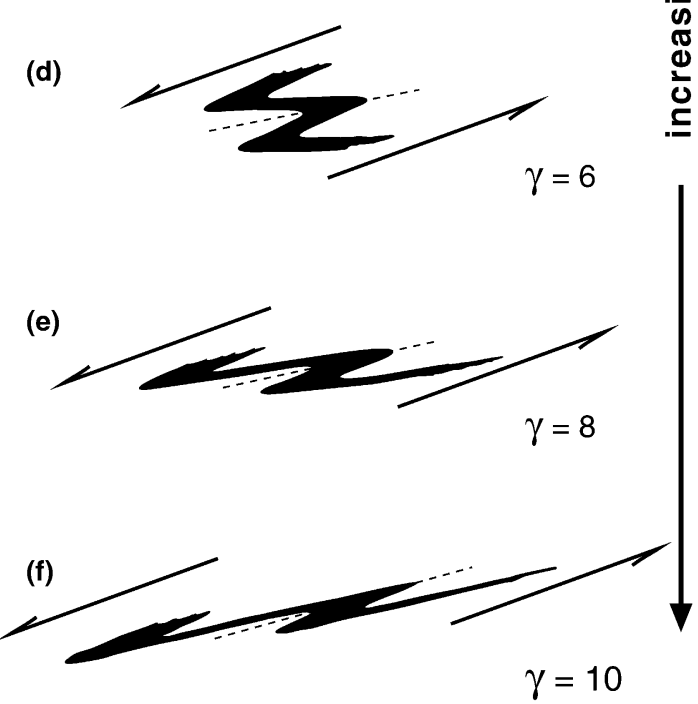

Fig. 10. Progressive folding of a layer within a shallowly dipping, normal ductile shear zone for increments of shear strain $(\gamma)$. Modified after Ramsay et al. (1983, fig. 4). Note that the asymmetry of early-formed folds $(b-c)$ is in agreement with the sense of displacement in the shear zone. The sense of asymmetry, however, reverses at higher strain (e-f). Outcrops of folds as in (e) and (f) could lead to a false, top to the right (i.e. thrust), interpretation in the absence of other shear criteria if facing and the progressive stages in fold development were not known. 
the Betic Cordillera, Spain, which, with the exception of Platt (1982) and Vissers et al. (1995), had previously been attributed to contractional nappe stacking, have been shown by Orozco et al. (1998) to have formed synchronous with displacement on low-angle normal faults during crustal extension. One such fold can be followed axially for over $50 \mathrm{~km}$ (Orozco et al., 1998). Examples of folds and other mesoscopic structural features associated with an extensional mylonitic shear zone are given by Snoke (1998).

Although there are some cases where folds may form parallel to the displacement direction (Bell and Hammond, 1984; Fossen and Rykkelid, 1990; also see Section 5.3 below), folds in ductile shear zones generally initiate with hinges normal, or at a high angle to the displacement direction. At low shear strain, folds are overturned towards the sense of shear (Fig. 10a-c) and are often noncylindrical (c.f. low-strain models of Cobbold and Quinquis, 1980). The enveloping surface of folds may rotate into the extensional field with progressive deformation, leading to a reversal in fold asymmetry (Fig. 10e-f). If nearby examples of lowstrain stages of fold development are not present, the opposite vergence of asymmetric folds seen in Fig. $10 \mathrm{f}$ could be misinterpreted as implying folding had occurred within a shallowly dipping thrust zone (i.e. a contractional, instead of extensional, tectonic setting could be incorrectly inferred). Misinterpretation is more likely to occur where facing criteria is not available to recognise overturning of layers at high shear strain, as is often the case in high-grade rocks.

Fold axes may also be reoriented towards the displacement direction with progressive deformation in the shear zone (Williams, 1978; Berthé and Brun, 1980). Folds with hinge lines conjugate about the displacement direction may develop during such reorientation (Brun and Choukroune, 1981). Sheath folds can form if strains are high at outcrop (Berthé and Brun, 1980; Cobbold and Quinquis, 1980) to kilometre scales (Mattauer, 1981; Lacassin and Mattauer,

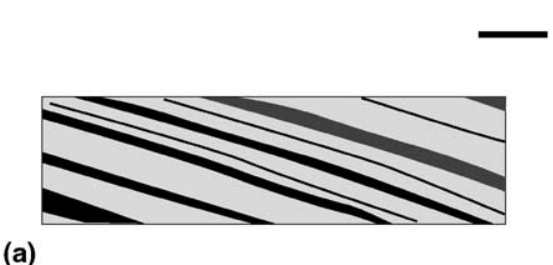

(a)

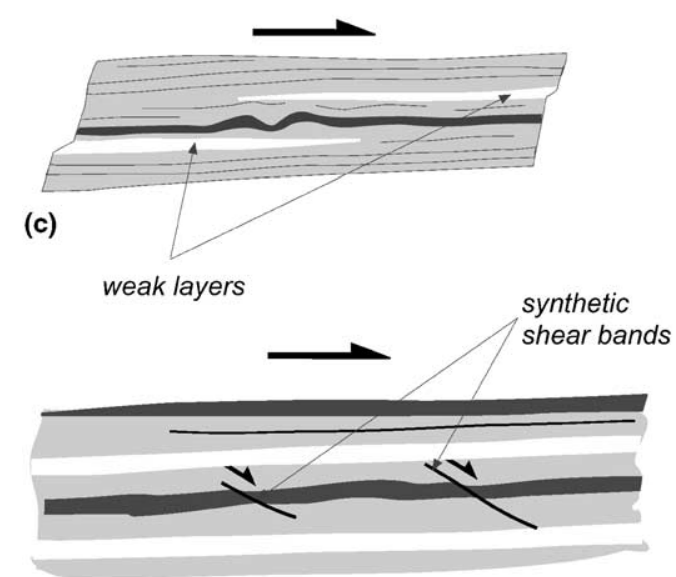

(e)

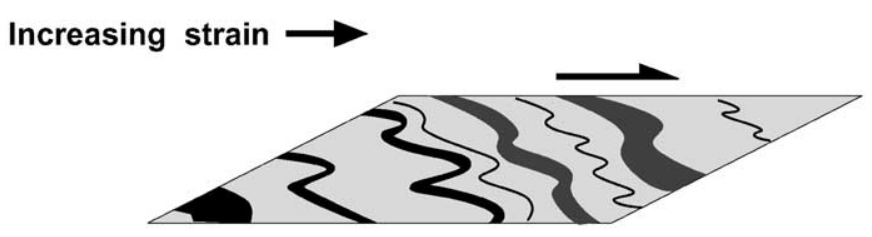

(b)
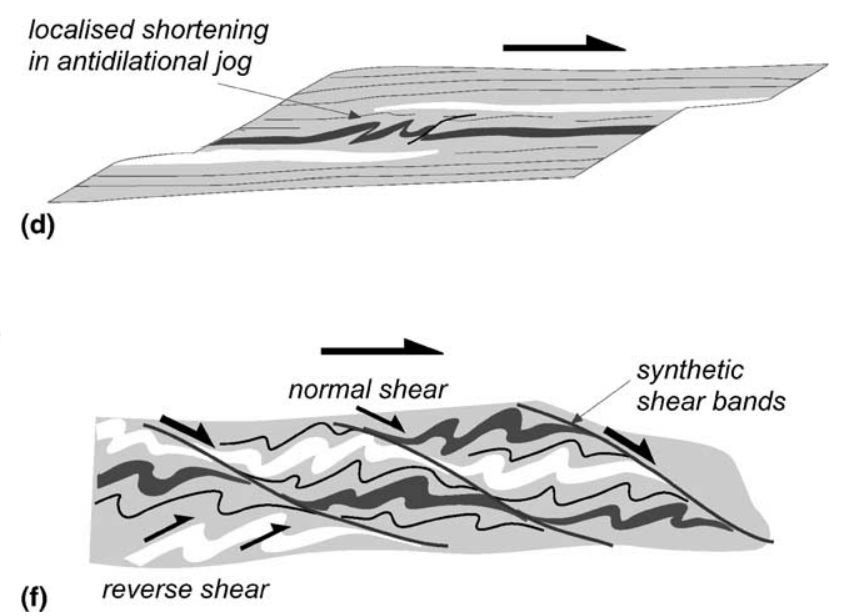

Fig. 11. Cross-sectional views (parallel to the transport direction) of folds developed in extensional detachments. (a-b) Foliation or compositional layering dipping steeper than the shear zone in the direction of shear is folded. (c-d) Transfer of slip from one weak layer (white) to another is one way of creating localised folds and thrusts in extensional tectonites. (e-f) Partitioning of bulk simple shear into extensional shear bands and folds is a common feature of mylonites. The two structures cause localised thinning and thickening of the zone respectively. 
1985). Sheath folds may themselves be refolded with progressive deformation (e.g. Faure and Malavieille, 1980).
Examples of sites for fold nucleation within extensional detachments are illustrated in Fig. 11. Layers dipping towards the sense of shear (Fig. 11a) are

(a)
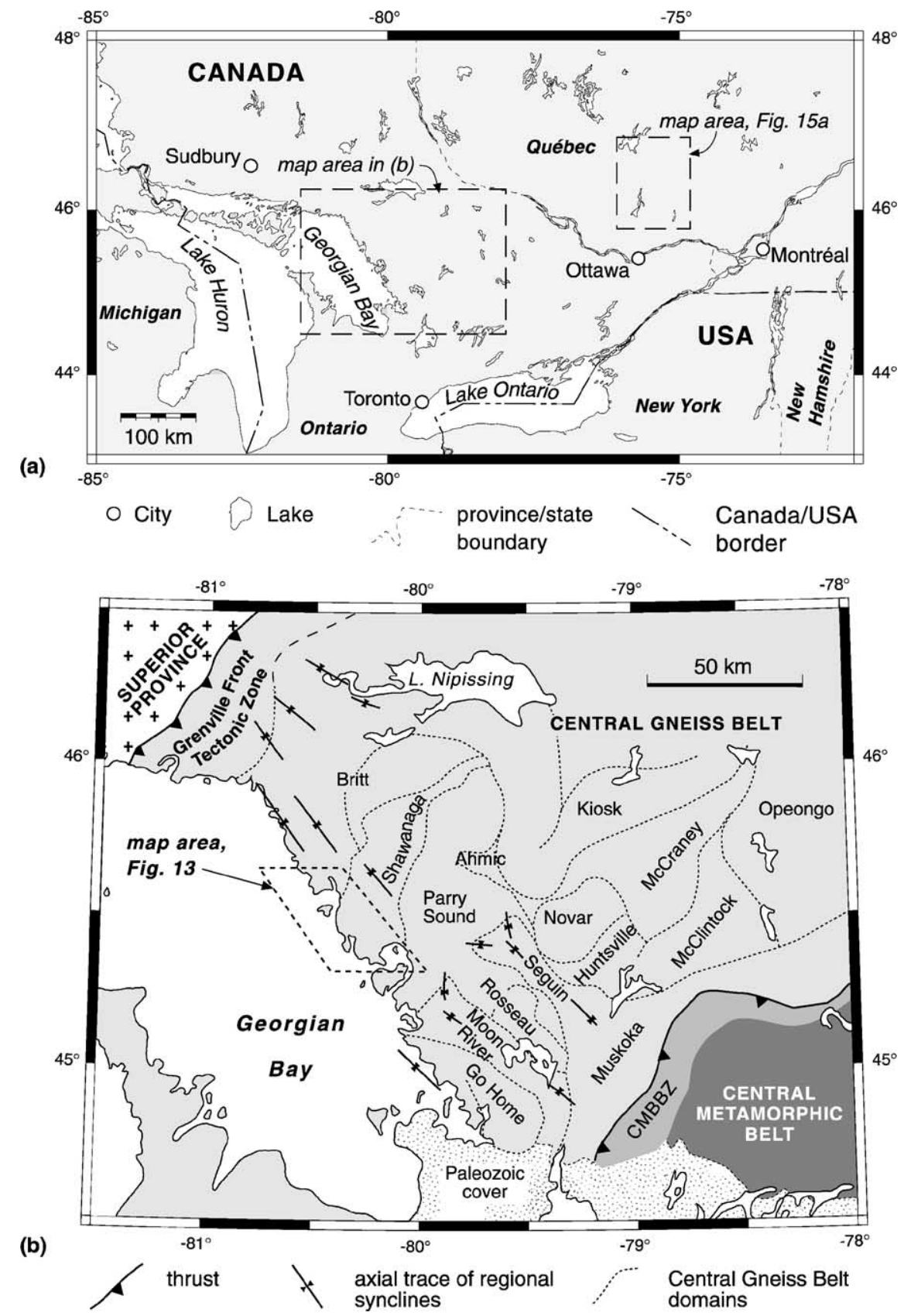

Fig. 12. (a) Location of geological maps in Ontario and Québec, Canada. (b) Map of the southwestern Grenville Province in the eastern Georgian Bay area of Ontario, Canada. Note regional fold axes orthogonal to the trend of the orogen. Compiled from Culshaw et al. (1994, 1997). Dashed lozenge shows location of maps in Fig. 13. 
folded asymmetrically, with fold vergence in agreement with the sense of shear, as described above. Folds of layering sub-parallel to shear zone margins may form where localised displacement is transferred upwards across the layering due to lithological heterogeneities (Rykkelid and Fossen, 1992; Fig. 11c-d). The presence of a localised contractional zone is analogous to antidilational (restraining) jogs in transcurrent fault zones. Perturbation of the layering around rigid objects, boudins or tectonic lenses, or other factors producing temporal and spatial variations in the velocity field, may also cause layer parallel shortening and hence folding (Hudleston, 1977; Platt, 1983; Bjørnerud, 1989).

Folds in extensional detachments also commonly form between synthetic shear bands ( $\mathrm{C}^{\prime}$ shears). In effect, they compensate fully (simple shear), partly or excessively (sub-simple shear) for the thinning of the zone imposed by the shear bands, and together they are a common expression of strain partitioning in exten- sional shear zones (Fig. 11e-f). Folds formed by displacement along a down-cutting normal shear zone (such as illustrated by Fossen and Holst, 1995, Fig. 4) are analogous to folds due to crumpling of soft rock layers above an inclined slope by Reyer (1888; reproduced by Hills, 1963) and within fold nappes emplaced by gravitational gliding (Lugeon, 1941; Brun and Merle, 1988; Merle, 1994).

\subsection{Formation of folds with axes parallel to the} maximum extension direction during displacement on extensional shear zones

The formation of complex, mechanically active, often noncylindrical buckle folds with axes parallel to the maximum elongation direction during displacement on extensional detachment shears has been described from the Canadian Grenville Province (Culshaw et al., 1994; Figs. 12 and 13), North American Cordillera (Malavieille, 1987a; Yin, 1991; Fletcher et
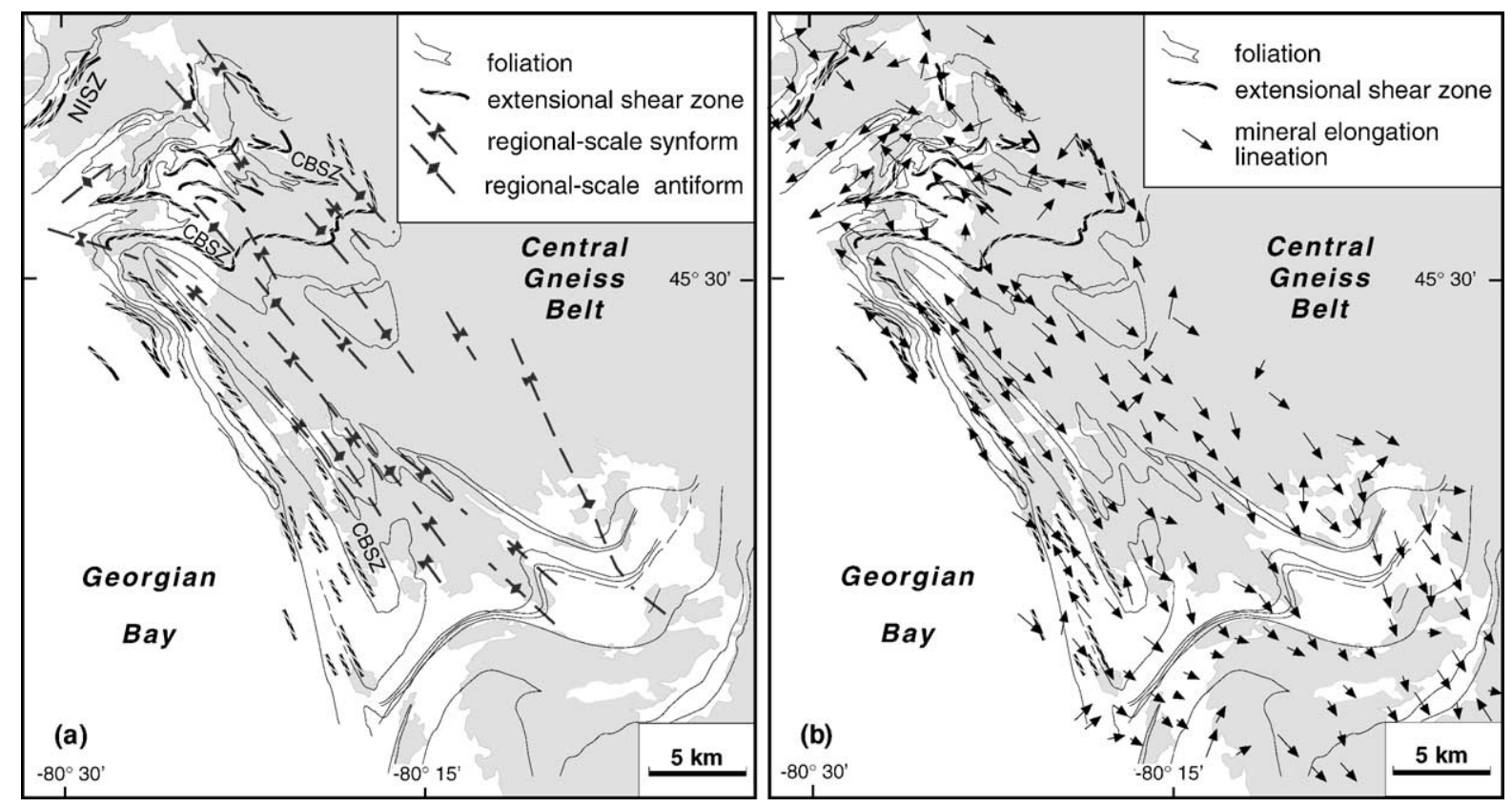

Fig. 13. Structures developed during extensional collapse in the southern Britt, Shawanaga, and western Parry Sound domains of the Central Gneiss Belt, southern Ontario Grenville Province (see Fig. 12 for location). Simplified after Culshaw et al. (1994). (a) Foliation trends and regional fold axial traces. Culshaw et al. (1994) conclude that folds developed with axes parallel to the extension/transport direction during extensional flow in the middle- to lower-crust. Folding is interpreted as being synchronous with extensional displacement on the Central Britt shear zone (CBSZ). Note folding of extensional detachments. NISZ=Nares Inlet shear zone. (b) Stretching lineations. Short arrows indicate steep plunges; long double-arrows indicate horizontal plunge. 
al., 1995), Scandinavian Caledonides (Chauvet and Séranne, 1994) and Alps (Mancktelow and Pavlis, 1994). This type of folding, which typically affects both the hanging-wall and the shear zone itself (Figs. 13 and 14), has been related to a reduction of the compressive stress in the shear direction during extension (Spencer, 1982). Numerical modelling indicates that the stress reduction itself in the extension direction is insufficient for extension-parallel folds to develop unless the magnitudes of the horizontal principal stresses $\left(\sigma_{1}\right.$ and $\left.\sigma_{2}\right)$ are relatively close (Yin,
1991). In this case, reduction of the vertical stress and increase of horizontal stress by tectonic denudation may cause $\sigma_{1}$ to switch from vertical to horizontal during or after extension (Fletcher et al., 1995). Yin (1991) also shows that detachment shear zones may be deformed by folds with axes parallel and orthogonal to the transport direction, forming dome and basin structures.

Folds parallel to the extension direction may form due to constrictional strains where flow occurs between syn-tectonic intrusives (shown schematically in Fig.

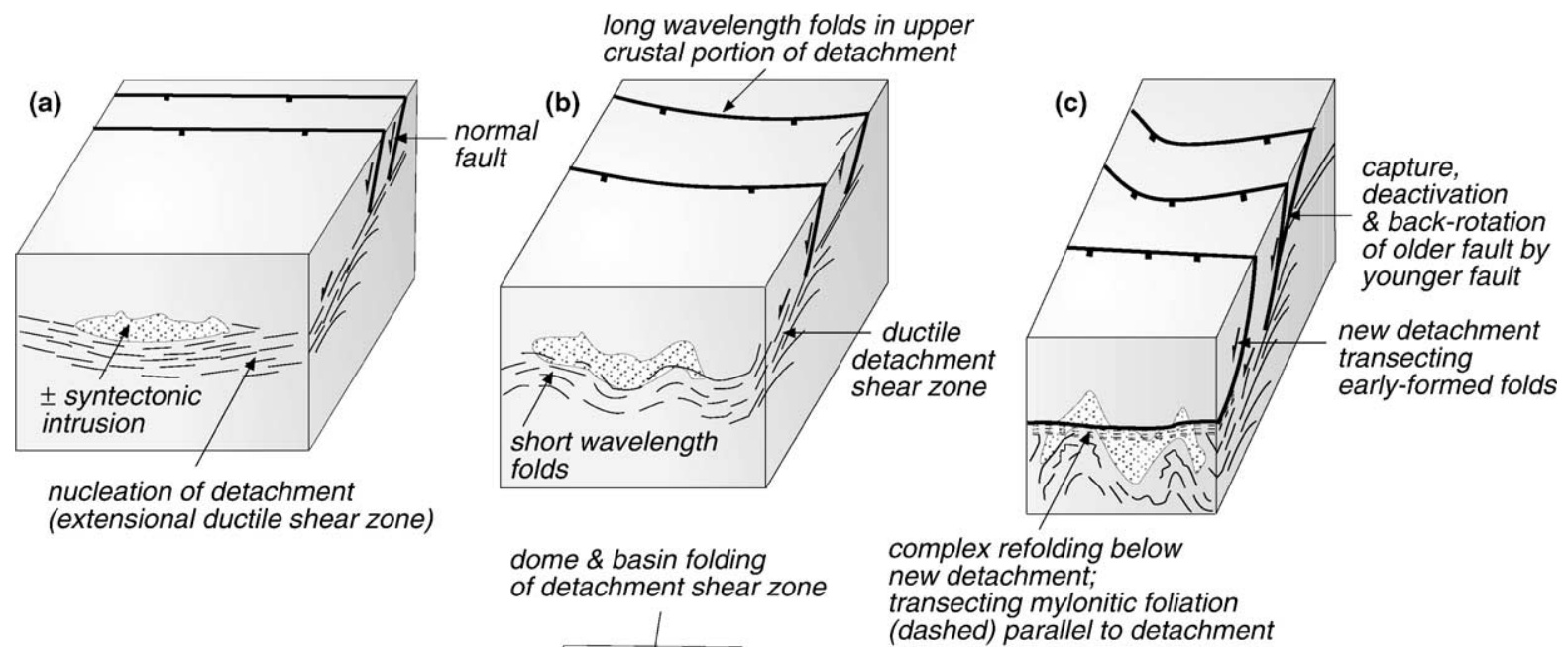

(d)

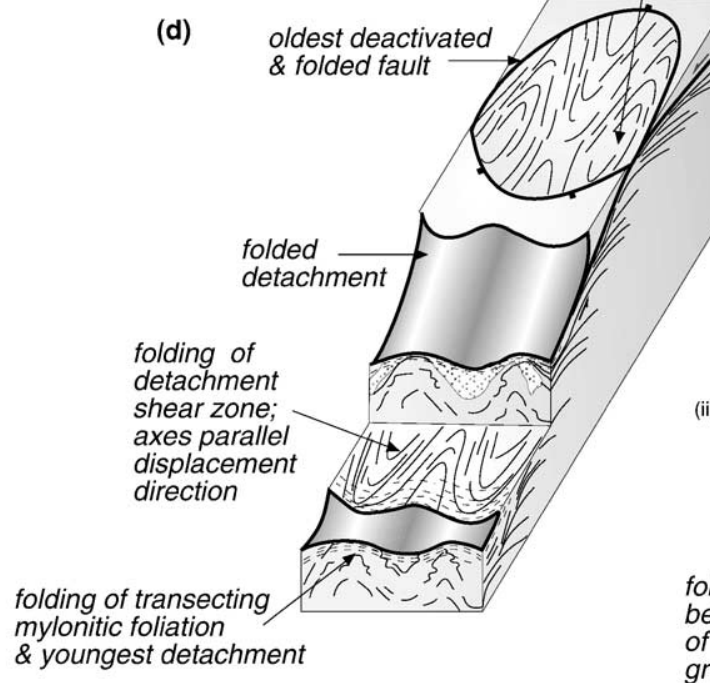

(ii)

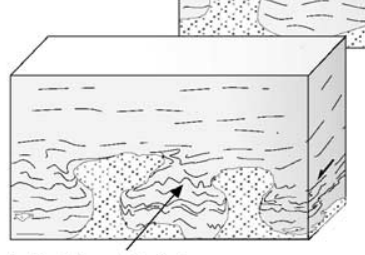

(e)

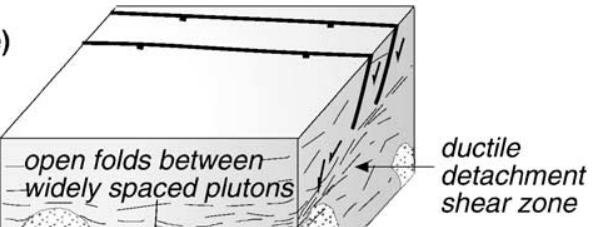

folds tighten if distance

between plutons decreases down-dip of the detachment, or if plutons grow laterally

Fig. 14. Schematic diagrams illustrating the progressive development and folding of extensional detachments and related structures about axes parallel to the displacement direction. Figures $(\mathrm{a}-\mathrm{d})$, after Mancktelow and Pavlis (1994), are based on their observations in the Simplon region of the Swiss Alps and Death Valley, California. (e) Folding of extensional detachment shear zones due to constrictional strains between plutons. 
14e) or due to lateral spreading of diapiric intrusions (Dirks et al., 1997, Fig. 8). An analogy may be made with folds in surge-type glaciers in which folds with axes parallel to the flow direction develop where the width of the valley in which the glacier is confined decreases down-slope (Lawson et al., 1994, fig. 7).

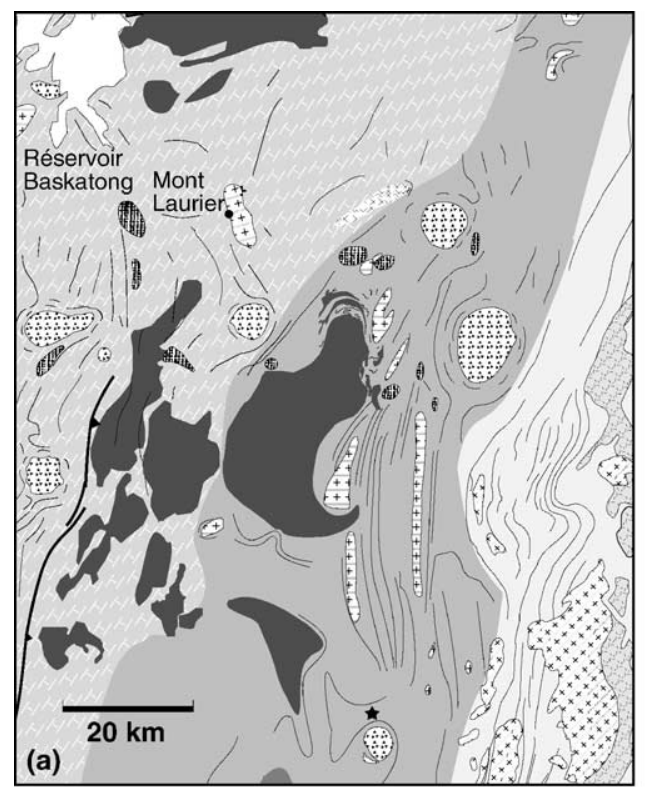

\section{Folds due to back-rotation between normal shear zones}

The development of folds in amphibolite to granulite facies gneisses due to back-rotation between ductile shear zones (Harris, in press) is an extremely

\subsection{Ga Guénette granite suite \\ 1.08 Ga Kensington syenite suite \\ 1.16-1.13 Ga \\ Morin AMCG suite mangerite, forsundite, gabbro \\ 1.17-1.16 Ga Chevreuil suite t+++++t diorite, gabbro \\ Morin Terrane $\quad$ paragneiss, amphibolite, charnockitic gneiss

\begin{tabular}{|l|l}
$\begin{array}{c}\text { Central } \\
\text { Metasedimentary } \\
\text { Belt }\end{array}$ & marble domain \\
& quartzite domain \\
& gneiss complex
\end{tabular}

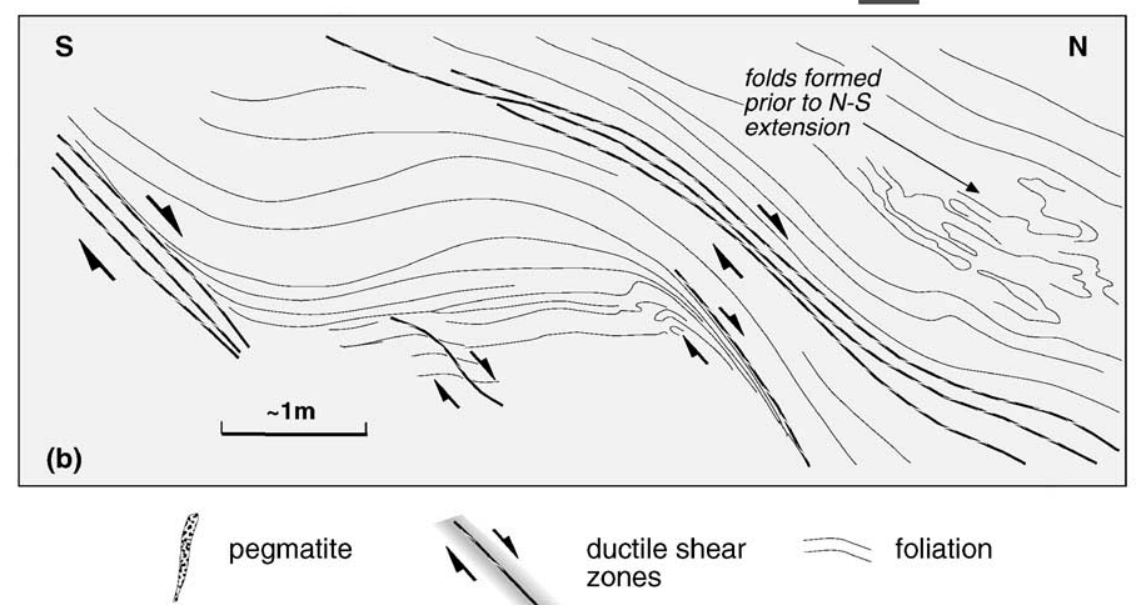

Fig. 15. (a) Simplified geological map of part of the Central Metasedimentary Belt modified after Corriveau and Jourdain (1993), Corriveau and van Breeman (2000), and Harris et al. (2001), and Morin Terrane in the Grenville Province of Québec. Morin Terrane geology modified after Avramchev and Piché (1981). Foliation trends in the Morin Terrane interpreted from satellite imagery. (b) Open folds formed due to a combination of ductile drag into E-striking normal shears zones and a minor amount of back-rotation between the shear zones. Quartzite Domain, Central Metasedimentary Belt (after Harris et al., 2001, fig. 8). See (a) for location. Note map-scale change from N-S to E-W foliation trends due to extensional folding of earlier structures. 


$\begin{array}{ll}\text { marker layer } & \begin{array}{l}\text { flattening } \\ \text { foliation }\end{array} \\ & \text { pegmatite } \\ & \text { incipient shear zone }\end{array}$

(b)

(a)

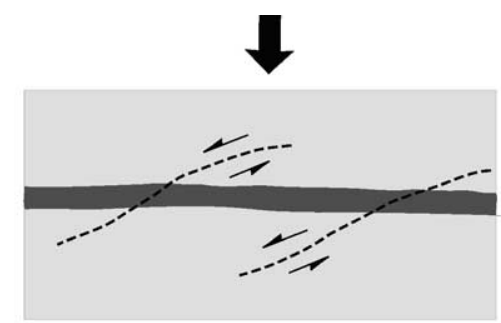

(c)
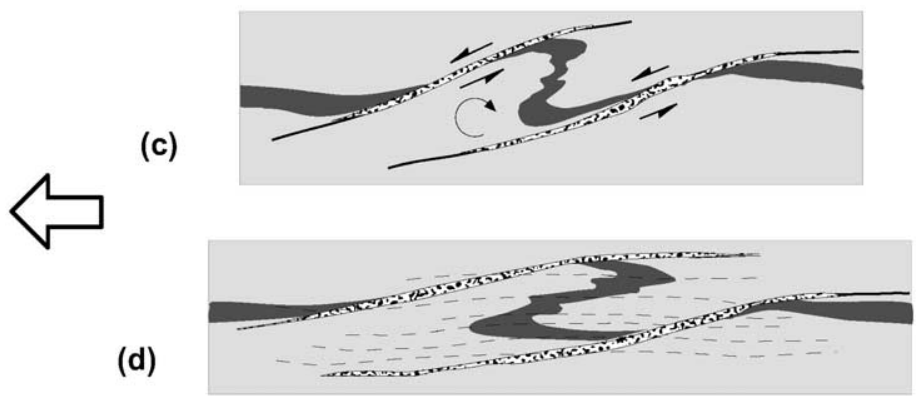

(d)
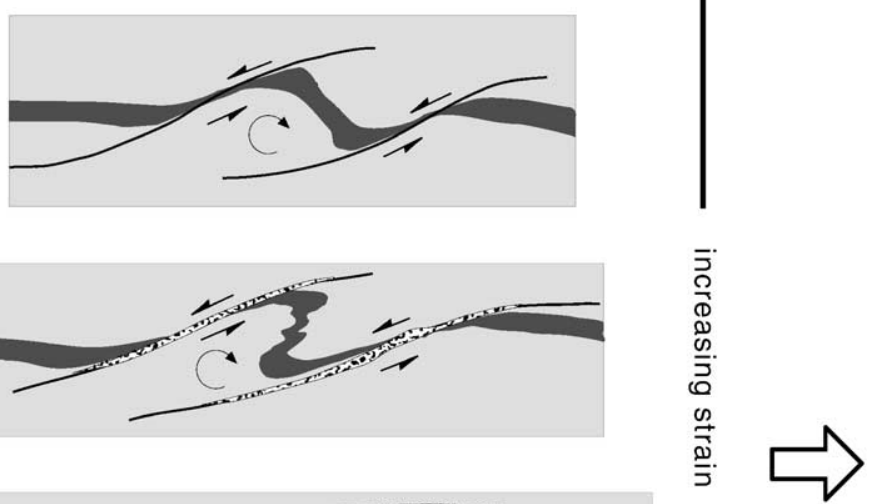

(e)
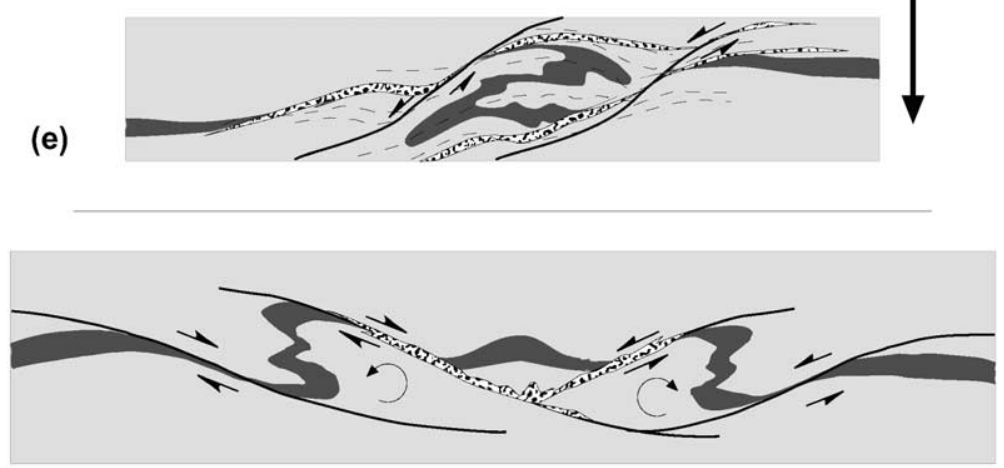

(f)

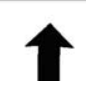

Fig. 16. Schematic diagrams showing development of folds between normal shear zones during horizontal extension (open arrows) and vertical loading (solid arrows). Modified after Harris (in press, fig. 9). Figures (a-e) portray the progressive folding of a layer between two normal shear zones. Changes in shape of the gray rectangle (of constant area) provide an indication of strain. (a) Horizontal layer cut by two normal ductile shear zones. (b) Back-rotation of layer during displacement on bounding shear zones. (c) Buckle folding of layer back-rotated into the flattening field. In migmatitic gneiss, in situ partial melt migrates into dilated shear zones to produce pegmatites sub-parallel to axial surfaces of folds. (d) Continued flattening of folds, development of axial planar foliations and rotation of inactive bounding shears and fold axial surfaces ( \pm pegmatites along them) towards orthogonality to the maximum shortening direction. (e) Folds may be refolded if cut by other sets of shear zones. (f) A separate example where folds with opposite vergence form due to the presence of conjugate shears. Open upright folds also develop above the intersection of conjugate shears. 
important mechanism to form folds in shallowly dipping layered amphibolite to granulite facies gneiss in extensional tectonic settings. A broad range of fold styles may develop in layers between two normal shear zones.

In the simplest case, such as in amphibolite facies gneiss in the Central Metasedimentary Belt of Québec (Fig. 15a), open folds can be produced due to the deflection of gneissosity and compositional layering into shear zones, combined with a small amount of ack-rotation between shears (e.g. Fig. 15b). Layers between two normal shear zones may also undergo greater amounts of back-rotation during displacement along bounding shears, as shown schematically in Fig. 16. Layers in the back-rotated domain commonly remain planar, with only their extremities being bent into the bounding shear zones (Fig. $16 \mathrm{~b})$. This is similar to the back-rotation of layering during formation of extensional crenulation cleavage (Fig. 9c).
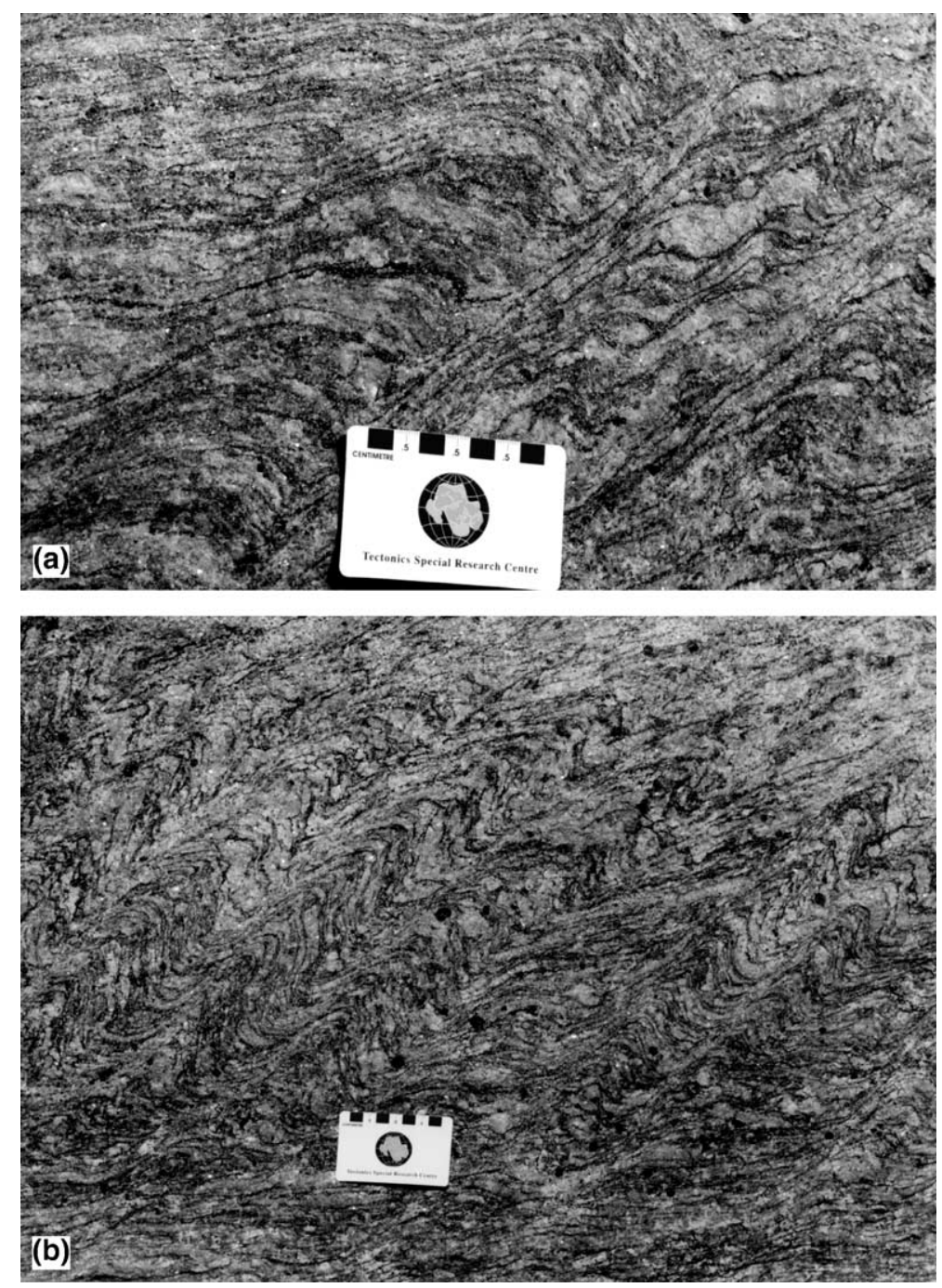

Fig. 17. Folds associated with displacement on normal shear zones in amphibolite facies gneiss of the Leeuwin Complex, Western Australia (see Fig. 18a-b for location). (a) Ductile drag of layers into normal shear zones results in open folds. (b) Inclined to overturned folds developed by back-rotation between normal shear ones. See line drawings in Fig. 18 for examples of stages in folding. Major divisions of scale bar are $1 \mathrm{~cm}$. 
In extensional crenulation cleavages described by Platt and Vissers (1980), deformed layers tend to undergo an average of about $17^{\circ}$ back-rotation and remain planar except for their deflection ("drag") into extensional shear zones. Complex folds may, however, develop with larger amounts of back-rotation. Increased back-rotation may be facilitated by the presence of melt along bounding shear zones in migmatitic gneiss. If shear zones are not parallel, or where the horizontal distance between shear zones remains constant or does not increase sufficiently to accommodate the length of back-rotated layers, layers must shorten during their back-rotation. Shortening will either result in thickening of layers where little or no mechanical contrast exists, or buckle folding where there is a greater mechanical contrast between layers. With increased back-rotation, folds amplify and layers are thinned by ductile drag along the bounding shear zones.

In migmatitic gneiss, partial melt generated in situ may migrate into the shear zones bounding fold packages forming pegmatites sub-parallel to fold axial surfaces. Pegmatites often have diffuse boundaries and can mask the presence of the shears. Layers between two shear zones may be back-rotated into the shortening field. Buckle folds may develop when there is a component of shortening acting parallel to the reoriented gneissic layering (Fig. 16c).

Rotation of shear zones as well as blocks between shear zones have been described for strike-slip deformation on the basis of structural and paleomagnetic studies (Ron et al., 1984; Garfunkel and Ron, 1985). A similar progressive rotation towards parallelism to the regional foliation is expected between normal shear zones. The presence of pegmatite veins along the shears can provide a mechanical contrast that facilitates their rotation. Fold axial surfaces and bounding shear zones may eventually be rotated into parallelism with the regional foliation producing intrafolial folds (Fig. 16d) and foliation-parallel pegmatite veins. These intrafolial folds and pegmatites developed along normal shear zones bounding fold packages may be refolded by folds between younger, crosscutting shear zones with progressive deformation (Fig. 16e). Crosssectional area is preserved in the schematic cross sections in Fig. 16a-e. Volume may, however, decrease in migmatitic gneiss due to the upward migration of melt generated in situ. Volume reduction can produce additional localised shortening/layer collapse and enhance folding between shear zones.

Where conjugate sets of closely spaced ductile shear zones are present, folds between each set of shears may develop contemporaneously, but with opposite asymmetry (Fig. 16f). Due to their similarity in style and timing with respect to other fabrics that may be present, the differences in their asymmetry may be misinterpreted as implying subsequent isoclinal refolding. Broad, open folds may also form between conjugate shear zones (Fig. 16f) in the vicinity of their intersections.

Figs. 17 and 18 provide examples of folding of an initially shallow dipping, high-grade gneissic foliation between closely spaced normal shear zones in the Neoproterozoic Leeuwin Complex of Western Australia (Fig. 18a-b). The Leeuwin Complex comprises 'A-type' granites, anorthosite and leucogabbro interpreted as forming within a continental rift and deformed and metamorphosed to amphibolite to granulite facies during the Neoproterozoic (Wilde and Murphy, 1990; Harris, 1994; Nelson, 1995). Normal shear zones developed during early crustal extension (Harris, 1994) are preserved in areas not significantly affected by subsequent folding. A continuous progression in the evolution of folds is seen from open

Fig. 18. Folds developed by back-rotation during horizontal extension in gneiss of the Neoproterozoic Leeuwin Complex, Western Australia. Line drawings of fold/shear zone relationships were traced from enlarged photographs of folds in vertical sections. (a-b) Location maps. Photos in Fig. 17 and sketches are from Bob's Hollow. (c) Gneissic foliation and early isoclinal folds (location A) are dragged into normal shear zones forming open folds (location B). (d) Isoclinal folds (A) and gneissic foliation are displaced by normal shear zones (B). Note that pegmatites developed along shears at C. Back-rotation between shear zones results in the formation of open upright (D), inclined (E) and overturned (F) folds. (e) Foliation below the zone of shear folding is horizontal to shallowly dipping except in the hinges of isoclinal folds such as at A. Shears range from broad and diffuse (B) to narrow, discrete structures (C). Back-rotation between converging shear zones has formed folds (D). (f) Folds range from open, dragged into shear zones (A and B), to close (C) to almost isoclinal (D). Note minor parasitic folds at E due to buckling of limbs steepened by back-rotation to have a component of shortening along them. (g) Increase in intensity of shear zones from broad warps at A, discrete shears at B, to broad zones of intense shearing at C. Single (e.g. D) or multiple wavelength folds (E and F) have formed by backrotation between shears. (h) Folds vary from open drag folds at A to isoclinal, overturned folds at B. Note that the gneissic foliation below the zone of folding and extensional shearing is unaffected (C). 

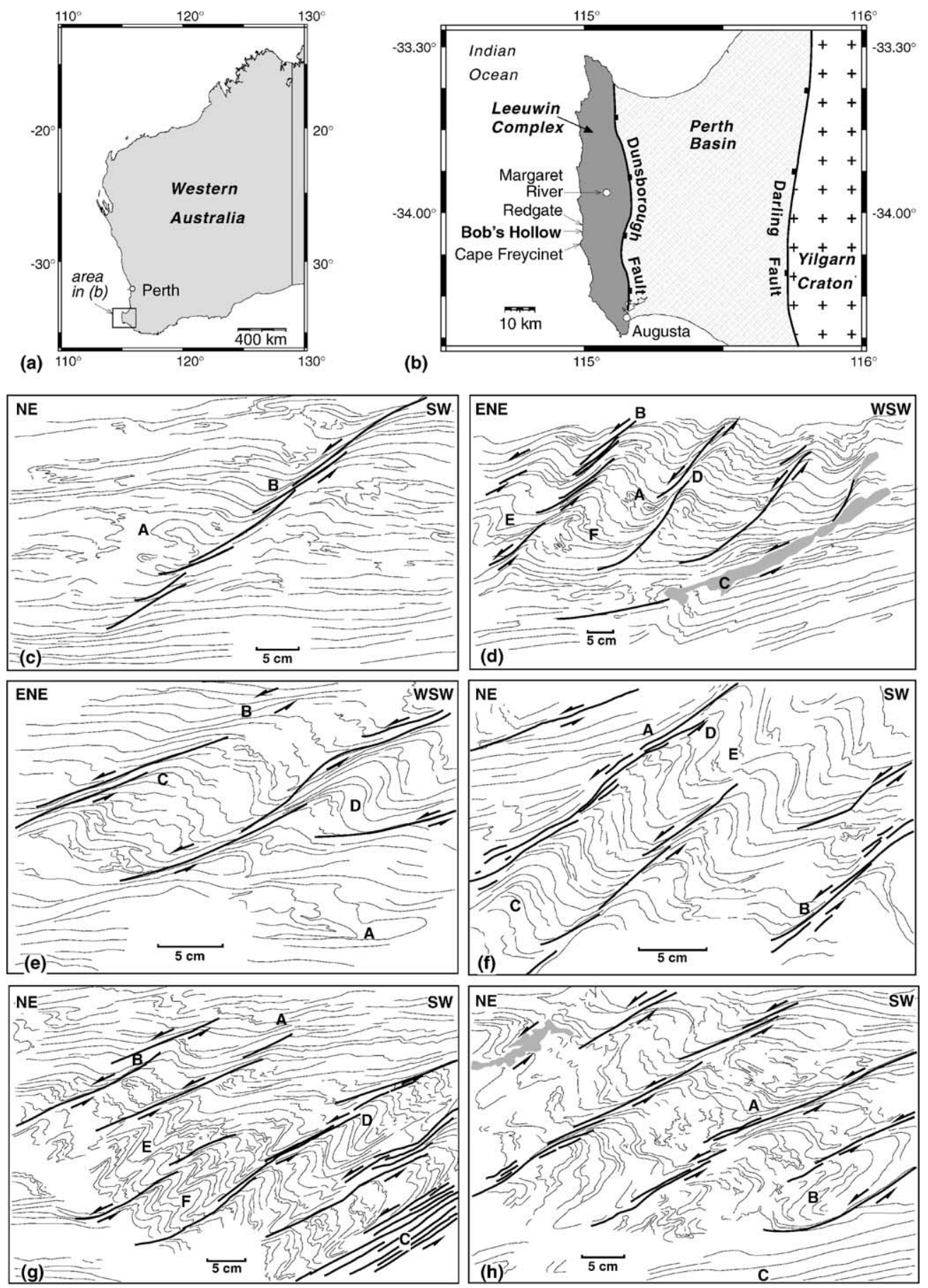

3) foliation

pegmatite 
ductile drag along normal shear zones in Figs. 17a and $18 \mathrm{c}-\mathrm{d}$ to tight, inclined to overturned folds in Figs. $17 \mathrm{~b}$ and $18 \mathrm{e}-\mathrm{h}$. It is important to realise that all folds, including tight buckle folds (such as at locations E-F in Fig. 18g) that require local layer parallel shortening, formed in an environment of regional vertical shortening and horizontal extension.

Folds formed between pairs of ductile shear zones have the opposite sense of asymmetry to the sense of displacement on the shear zones. In areas of shallowly dipping foliation, folds formed between normal shear zones may therefore be easily misinterpreted as indicating thrust tectonic transport. A bulk contractional, instead of extensional, tectonic setting may, therefore, be incorrectly deduced. Criteria that help distinguish folds formed between normal shear zones from those formed during thrusting are as follows:

(i) Presence of syn-folding pegmatites sub-parallel to axial surfaces in migmatitic gneiss. This is, however, not unique to folds formed by back-rotation. High fluid pressure, transitory relaxation of stresses, boudinage and dilational jogs are also suggested by Vernon and Paterson (2001) for the formation of axial planar leucosomes. (ii) Fold development in packages; outside zones of intense folding a regional foliation may be constant in orientation. Where a definite marker horizon can be identified (not always possible in uniformly banded gneisses), there is no reverse offset on either side of the fold package. Folds in separate 'packages' may show an opposite sense of vergence that cannot be explained as being due to conjugate kink folds or parasitic folds around a larger fold closure.

(iii) In areas of shallowly dipping regional foliation, overturned fold limbs that would be expected to have thinned after early thickening in shear or kinkstyle folding (Plotnikov, 1994, Chapter 6) are typically thicker than upright limbs.

(iv) Normal shear zones developed in the same event crosscut transposed folds.

A single criterion cannot be used to determine fold mechanisms, but the presence of several of the above features would suggest a model of folding due to back-rotation between extensional shear zones to be highly likely.

Analogue modelling by Gartrell (1997; Fig. 19) and comparison of models with deep reflection seismic profiles across orogens (e.g. Lithoprobe sections across
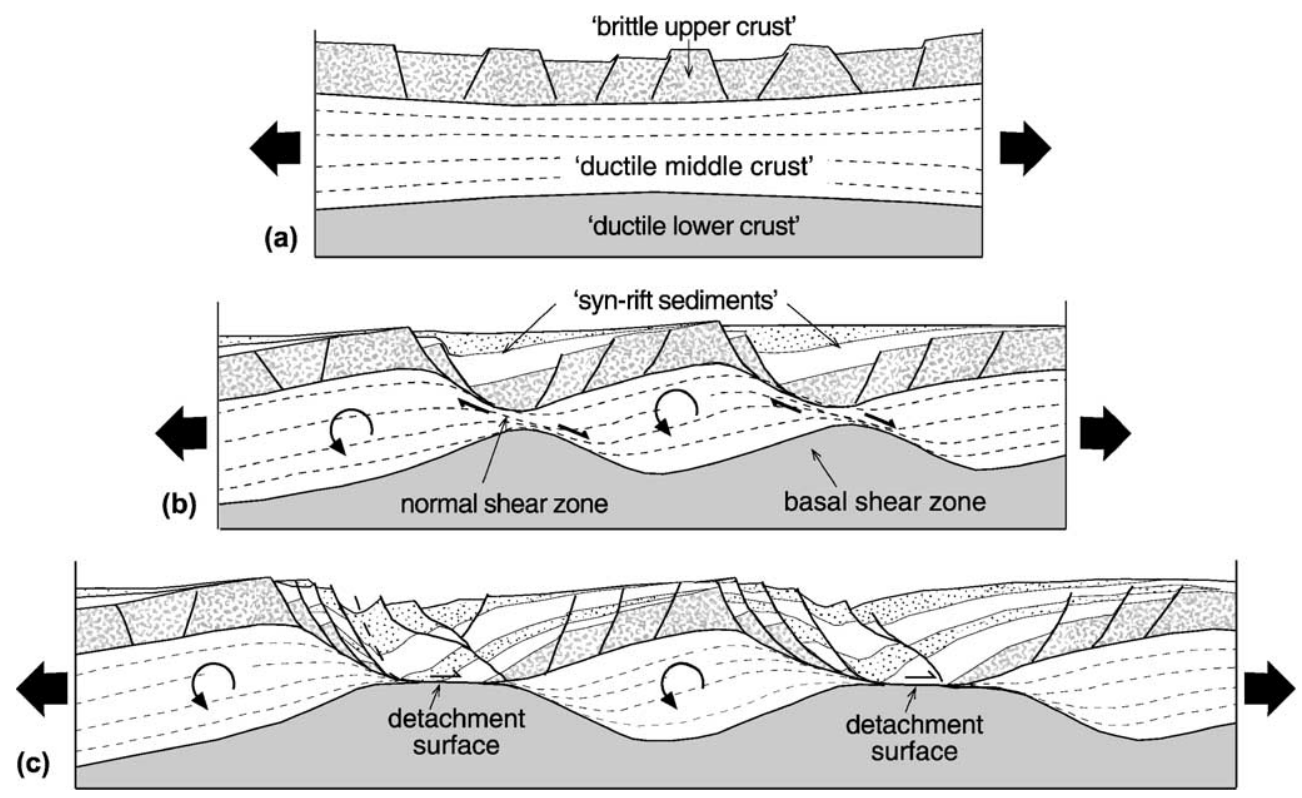

Fig. 19. Schematic diagrams based on $1 \mathrm{~g}$ analogue modelling of rifting where there has been boudinage of a more competent middle crustal layer (simplified after Gartrell, 1997). Back-rotation of blocks between normal shear zones localised in boudin necks results in broad open folds. Similar crustal-scale structures in nature may lead to exhumation of high-grade rocks. 
the Grenville Province of Québec in Martignole and Calvert, 1996 and interpretations of deep seismic profiles from Southern Norway by Andersen, 1998) suggests that back-rotation between extensional shear zones may occur at regional and crustal scales as well. Back-rotation between regional extensional shear zones may result in open, regional folding and exhumation of high-grade rocks in cores of extensional antiforms to form elongate gneiss domes. Exhumation of high-grade rocks during block rotation between normal shear zones is portrayed on cross sections from Southern Norway by Milnes et al. (1997, figs. 1 and 5) and Andersen (1998, figs. 4 and 5).

\section{Folds due to necking and boudinage}

Johnson and Fletcher (1994) demonstrate that folds and pinch-and-swell structures may develop in layers of a material that behaves as a nonlinear, power-law fluid during extension parallel to the layering. In comparison to folding due to gravitational instabilities (as described by Ramberg, 1973), no density contrasts are required between layers for pinch-and-swell structures to develop. Early workers such as Lohest (1909), Cloos (1947) and Rast (1956) describe how competent layers in a less competent matrix may neck and eventually separate to form boudins during layerparallel extension. Boudin necklines generally form perpendicular to the orientation of resolved maximum extension in the plane of the boudinaged layer. In thin competent layers boudin necklines may, however, form at lesser angles to the maximum extension direction due to failure and separation along earlyformed deformation bands analogous to Lüder's Bands in metals (Burg and Harris, 1982).

In extensional tectonic settings, boudins commonly develop at the outcrop to regional scale where there

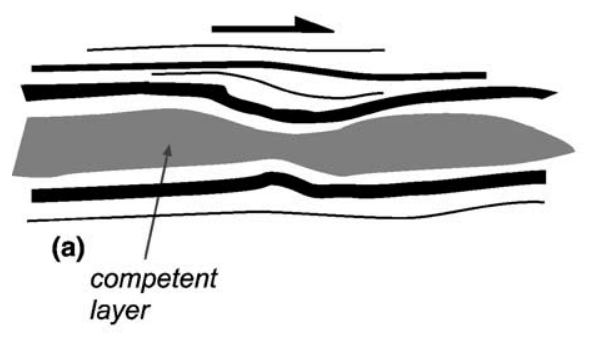

(b)

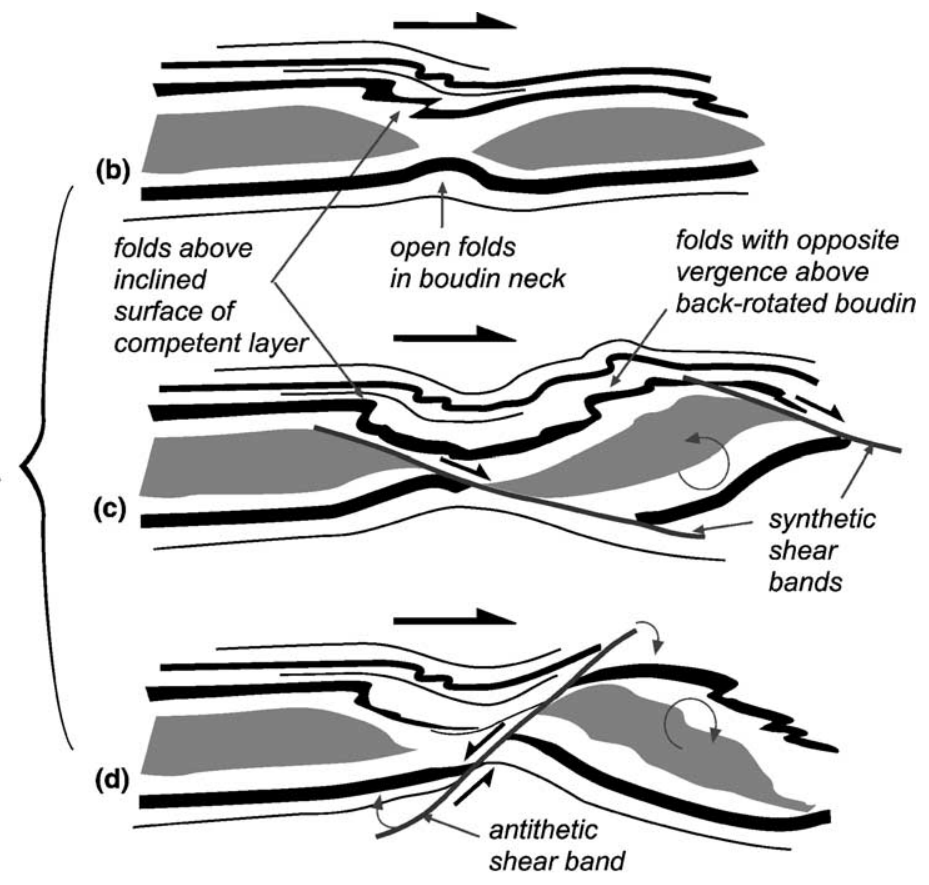

Fig. 20. Structures associated with boudins in extensional detachments. (a) Necking of competent layer. Initiation of overturned and open folds in adjacent layers. (b) Foliation curving ahead of boudins or tectonic lenses is likely to become folded due to differences in flow rate over the boudin (illustrated by Brun and Merle, 1988, fig. 3). Fold trains may successively form upwards from this location with continued shear. (c) Folds with the opposite vergence to the bulk sense of shear result from the back-rotation of a boudin between synthetic, secondary shear zones. (d) Folds with the same vergence to the bulk sense of shear develop ahead and in the leading edge of the boudin due to forward-rotation of a boudin. Antithetic secondary shear zones are likely to forward-rotate with progressive deformation. 
Table 1

Composition of layers in centrifuge experiments shown in Fig. $21 \mathrm{a}-\mathrm{d}$

\begin{tabular}{lll}
\hline Package & Model 1 & Model 2 \\
\hline C & $\begin{array}{l}\text { competent layers = plastilina }+ \text { Canderel } \\
\text { making them less dense and more brittle than those in B; ductile matrix = Dow Corning silicone }\end{array}$ \\
B & competent plastilina horizons in a ductile Dow Corning silicone matrix \\
A & $\begin{array}{l}\text { ductile mix of Rhone Poulenc Rhodosil Gomme, } \\
\text { mixed with iron oxide to increase density and }\end{array}$ & $\begin{array}{l}\text { viscous layers (plastilina }+ \text { silicone mix) with only } \\
\text { acid oil to decrease viscosity }\end{array}$
\end{tabular}

are competence contrasts between individual layers or layer packages. Folds are developed in the less competent layers as they are drawn into boudin necks (Fig. $20 \mathrm{a}-\mathrm{b})$. In areas of limited outcrop, large boudins may not be seen and folds in boudin necks could easily be misinterpreted as indicating layer-parallel contraction.

In extensional detachments, a pinch-and-swell structure developed in a more competent layer may also induce folds overturned in the sense of shearing in overlying layers (Fig. 20a). With increased strain, the competent layer may separate to form boudins. Where boudins separate without significant rotation, early-formed folds may continue to amplify and new overturned folds develop above the boudins due variable flow rates over the boudin (Fig. 20b). The process of folding here is equivalent to models of folds developed over basement heterogenities by Brun and Merle (1988). Boudins in shear zones may either forward- or back-rotate. Back-rotation occurs if synthetic shear zones form in boudin necks (Fig. 20c). The backward-rotation of boudins may produce folds with the opposite vergence to early-formed folds in both the leading edge of the rotated boudin and in overlying layers (Fig. 20c). During forward rotation, an antithetic shear generally forms in the boudin neck (Fig. 20d). Folds in both the leading edge of the rotated boudin and in overlying layers will be overturned in the same sense as the bulk sense of shear.

Complications may arise in migmatitic gneiss in interpreting the significance of boudins (as well as minor extensional faults and normal shear bands) as they do not necessarily indicate regional layer-parallel extension. Bons (1999) shows that such structures may form even during bulk layer-parallel shortening as a result of volume loss due to melt extraction and differences in rates of extension or contraction between adjacent layers.

Boudinage may also occur at crustal and lithospheric scales. Zuber et al. (1986) have shown that necking instabilities at two wavelengths will result in upright, regional-scale folding in an extending continental lithosphere where a strong upper crust is separated from a strong upper mantle by a weak lower crust. Sub-horizontal ductile shear zones are initiated in the upper part of the weak lower crust in the model of Zuber et al. (1986). These form due to necking of the upper crust,

Fig. 21. Centrifuge modelling of structures formed by extension parallel to an initially planar layering. See Table 1 for composition of models in $(a-d)$. (a) Boudinage of competent red and black plastilina layers in a less competent (silicone-plastilina) matrix producing open, upright folds. The basal layer (A), which is denser and less viscous than ductile layers in package B, has flowed between boudins in package B. (b-d) Passively coloured viscous ductile basal layers (package A) are overlain by a package of competent green and white plastilina layers and less dense silicone layers (package B) and by a second package of more brittle black and brown layers in passively coloured ductile layers (package C). (b) Sructures resulting from a combination of boudinage and displacement on normal shear zones in layer packages B and C. Boudinage of both thin green competent layers and multi-layers in package B dominate the region from the centre to the left margin of the model. Note the formation of upright to inclined folds above a normal shear zone and thinning of basal layers (package A) to the right of the section. A wide range of deformation styles formed during layer parallel extension (from open upright to refolded isoclinal recumbent folds) is shown on details of parallel slices in (c) and (d). (e-f) Examples of centrifuge rift models of Harris and Koyi (in press). Models comprise a lowermost ductile layer (black) representing the asthenosphere, a competent semi-brittle layer representing mantle lithosphere (green), ductile layers with thin inter-layered white and green competent horizons to model the middle and lower crust and a brittle upper crust. (e) Oblique view of an asymmetric rift model showing 'asthenosphere' layer bowed up in the gap created due to separation of the 'mantle lithosphere' layer (green), similar to asymmetric rifting portrayed in Fig. $2 \mathrm{~b}-\mathrm{d}$. Note flattening of mantle lithosphere footwall. (f) Cross section showing refolded isoclinal recumbent folds in layers representing the lower ductile crust whereas the upper brittle layers form a simple sag basin. 


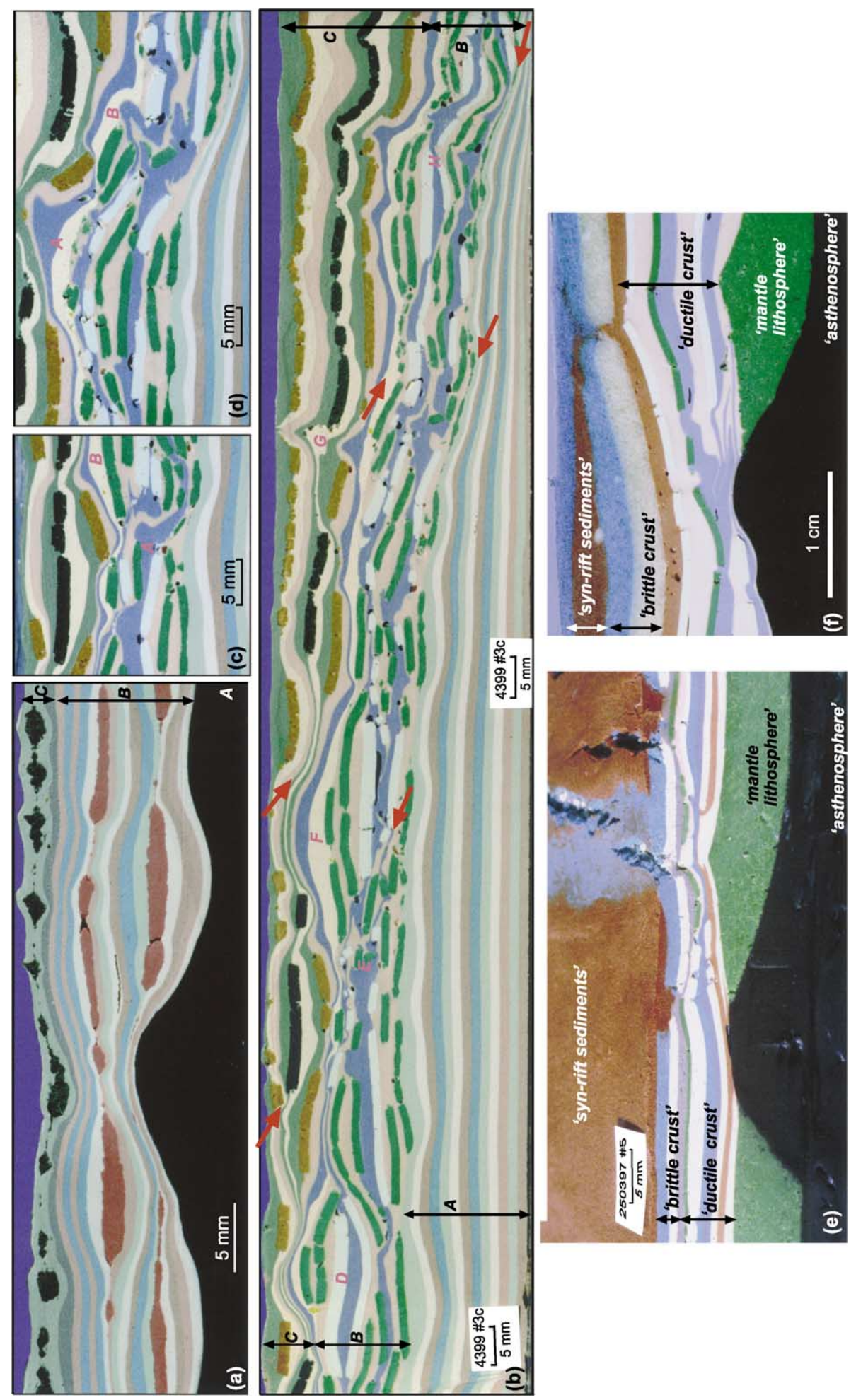


and may equate to low-angle extensional detachments along which folds may develop (as described in Section 9.1 below). Necking and boudinage of extended lower crustal layers are also important features of the analogue models of Gartrell (1997, Fig. 19) where they have controlled the style and localisation of shear zones in the ductile crust and normal faults in the upper, brittle crust.

\section{Centrifuge modelling of structures in high-grade rocks during layer-parallel extension}

Several centrifuge models have been constructed to show the development of structures in materials that represent compositionally layered high-grade gneisses (see Table 1 for composition of layers). Concepts of scaling of centrifuge models are discussed by Ramberg (1967, 1973, 1981) and Dixon and Summers (1985). The models were assembled in a rig with a moveable end-wall (right side of models) as used by Harris and Koyi (in press). Removable spacers permitted the model to extend parallel to the initial layering whilst undergoing an acceleration of approximately $900 \mathrm{G}$ (acting normal to the initial layering) in the large centrifuge in the Hans Ramberg Tectonic Laboratory, Uppsala.

Model 1 is dominated by the formation of boudins of the package containing competent plastilina layers and of individual plastilina layers (Fig. 21a). The surrounding ductile layers in package $\mathrm{B}$ have bent to infill gaps between boudins of the competent plastilina layers; open, upright folds characteristic of pinchand-swell structures and boudinage form. The basal ductile, less viscous, but denser layer has also risen beneath the boudin necks. The competent layer in package $\mathrm{C}$ has also boudinaged. Boudin spacing is less here due to the more brittle nature of the competent layer than for those in package B.

Model 2 (with a more viscous basal package; see Table 1) shows the inter-relationship between boudinage of competent layers, normal shear zones and folds in the ductile matrix. Fig. $21 \mathrm{~b}$ presents a complete slice of model 2 after approximately $100 \%$ elongation. The basal package is thinned (especially in the far right of the model where its thickness is greatly reduced beneath a normal shear zone) and exhibits open, upright folds of its uppermost layers. If only rocks of a similar system in nature equating to the upper part of the basal package were to outcrop, one would surely interpret these simple structures as forming due to a minor amount of horizontal shortening. Indeed, the boudinage of overlying competent layers could be easily misinterpreted as resulting from local extension in the outer arc over antiforms during horizontal contraction, instead of extension parallel to the initial layering. Individual competent layers in the middle and upper packages of Fig. 21b have boudinaged and separated, with thinned ductile layers flowing to fill the inter-boudin gaps.

The central package also contains larger, composite boudins composed of both competent and ductile multi-layers. Extension of groups of layers to form composite boudins has resulted in upright to inclined, large wavelength, open folds (Fig. 21c). Normal shear zones have locally developed in the regions between these composite boudins (Fig. 21d). Overturned to recumbent folds are formed in broad shear zones (Fig. $21 b-d)$. These folds form due to progressive deformation of initially upright folds of ductile layers between individual boudinaged layers. Recumbent folds are much tighter, and have less rounded hinges, than the upright folds. They sometimes show an incongruent vergence with respect to upright folds from which they evolve (e.g. Fig 21c). A variety of fold styles and overprinting relationships, which in nature could be interpreted as polyphase folding during regional contraction, are thus developed during a single episode of extension parallel to layering.

Folding resulting from ductile flow during rifting has been modelled by Koyi and Harris (2001) and Harris and Koyi (in press). These centrifuge models were scaled to represent a brittle 'upper crust', a ductile 'middle-lower crust' with thin competent layers, and a competent 'lithospheric mantle' (Fig. 21e-f). An asymmetric rift system (Fig. 21e) developed when models were extended parallel to the original layering (under the same conditions as for the experiments described in Section 4). Although upper layers show a simple fault-bounded or sag basin, the underlying ductile layers are complexly folded (Fig. 21f).

Harris and Koyi (in press) identify several different folding mechanisms. Open upright to inclined folds were formed between conjugate ductile shear zones and within boudin necks. Inclined folds occur between closely spaced parallel normal shear zones. Upright to inclined folds developed above the crest of the rotated mantle lithosphere footwall during early stages of 
rifting and displacement on a shear zone that cuts the lithospheric mantle (Fig. 22a). These were tightened and their axial surfaces rotated to sub-horizontal with further extension (Fig. 22b). At high strain, fold nappes with attenuated lower limbs were developed above shallowly dipping ductile shear zones (Fig. 22c). Isoclinal recumbent folds are refolded during doming of the material representing the asthenosphere (Fig. 22d). Fig. 22e of a second, similar model shows isoclinal recumbent folds formed during flow above the inclined
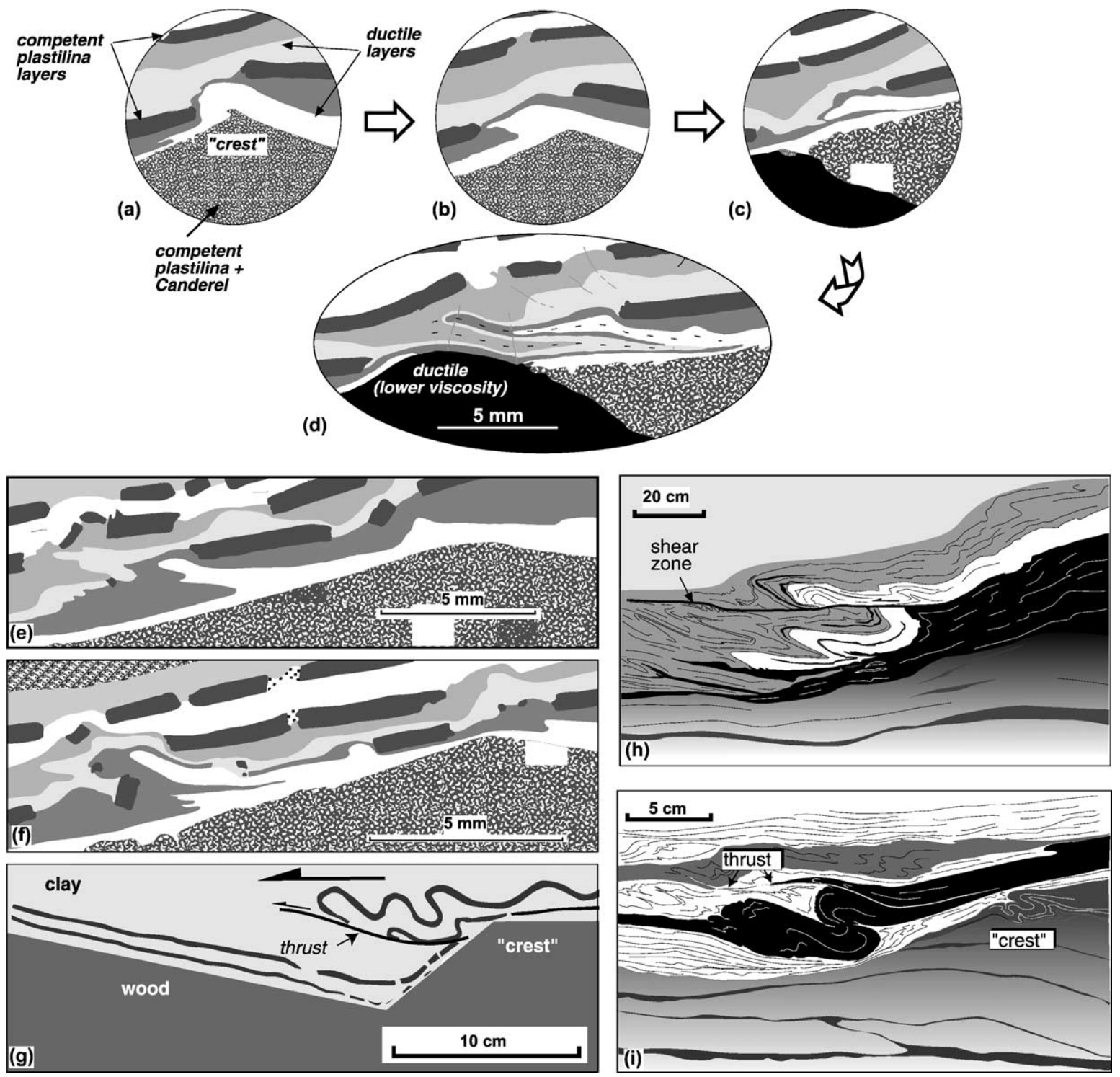

Fig. 22. (a-d) Line drawings from photographs showing three stages of the formation of folds in a broad shear zone above the rotated mantle lithosphere footwall of the centrifuge model in Fig. 21f. (e-f) Details of refolded isoclinal recumbent folds in layers representing ductile lower crust in a similar rift model. Note also boudinage of thin competent layers. (g) Folds and thrust formed beyond the crest of irregular basement. Clay experiment described in Fossen and Rykkelid (1992). (h-i) Natural examples of fold-thrust relationships as modelled in (g) from an extensional shear zone in gneisses of the Øygarden Complex on the island of Toftøy, Norway (Fig. 23b). Note how the folding is restricted to the area in front of the crest and development of a small thrust in (i). 
basal layer which are later folded during flow into necks of overlying boudins (Fig. 22f). Folds similar to the above structures accompanied by shallowly dipping thrusts were also modelled using clay (Fossen and Rykkelid, 1992; Fig. 22g).

\section{Examples of folding in amphibolite and} granulite facies rocks in regional extensional tectonic settings

\subsection{The Caledonian basal décollement of southwest- ern Norway}

Folds are abundant in the basal décollement zone separating the Baltican basement from the overlying orogenic wedge in southwestern Norway (Fig. 23). This zone was the basal thrust zone during SEdirected Caledonian nappe translations in the late Ordovician and Silurian (e.g. Hossock and Cooper, 1986; Milnes and Koestler, 1985). Systematic kinematic analysis of the zone revealed that the overall dominating mylonitic fabrics consistently indicate top-to-NW transport. Closer examination revealed that the NW-verging fabrics were superposed on SE-directed, thrust-related Caledonian structures, turning the main Caledonian thrust zone into an early Devonian extensional shear zone (Fossen, 1992).

It is intriguing that this extensional shear zone is in many places dominated internally by contractional top-to-NW structures, illustrating the important
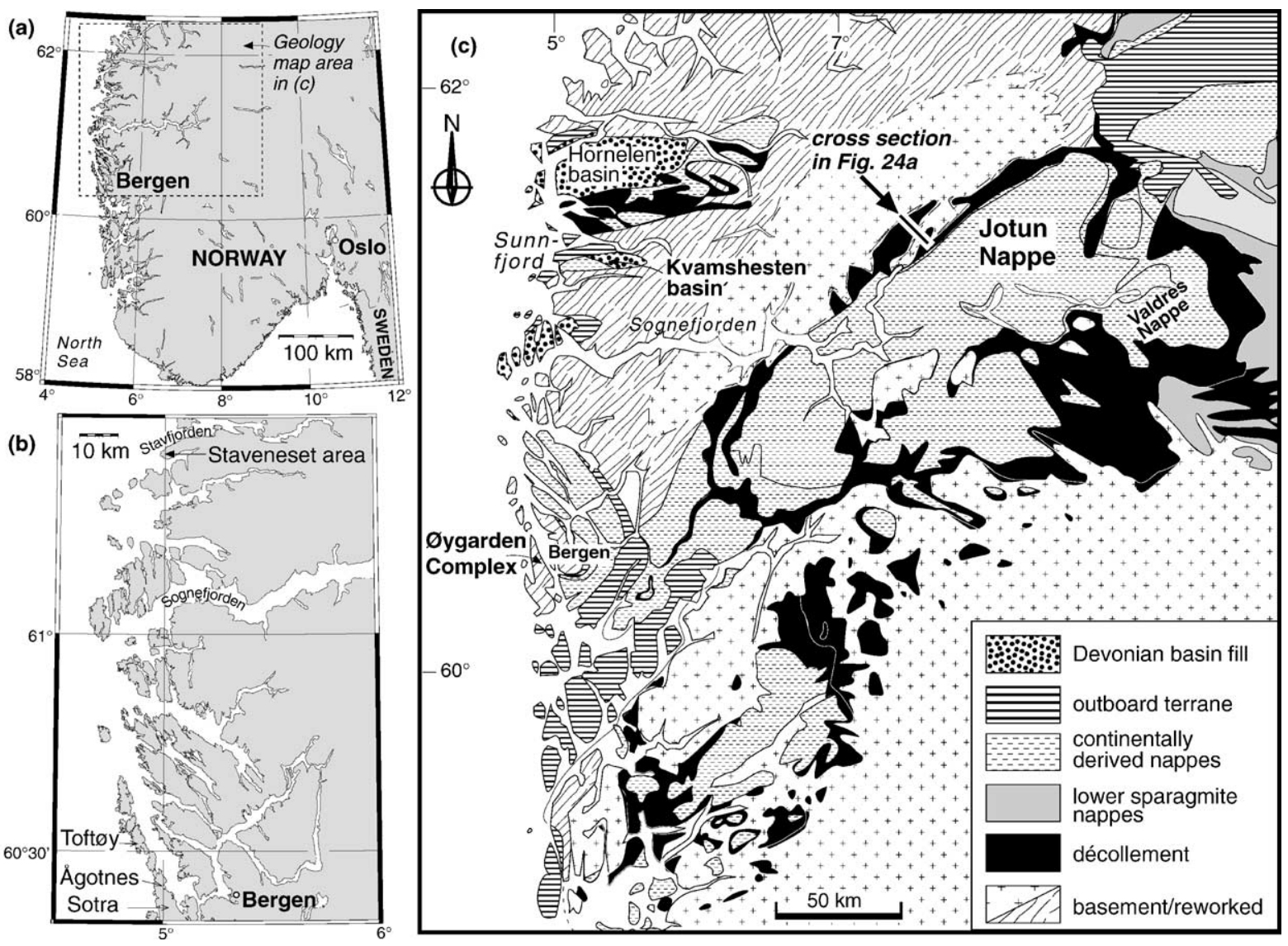

Fig. 23. Location maps for structures developed within Caledonian extensional detachments, Norway. (a-b) Situation of sites. (c) Simplified geological map of western Norway showing location of cross section through the Jotun nappe and its basal décollement in Fig. 24a and the Øygarden Complex (see sketches in Fig. 22h-i and photographs in Fig. 25). 
distinction between structures developed internally in a shear zone and its large-scale, tectonic nature. Contractional structures are dominated by asymmetric, NW-verging folds ranging from micro-scale to map-scale (Fossen and Holst, 1995; Fig. 24a). The reason for the abundant folding during the Devonian extensional shearing along the décollement zone is thought to be related to the change in the instantaneous stretching direction from thrusting to extension. Foliations and layering rotate towards the shear plane during simple shearing. Hence, at the end of the thrusting history, the foliation was dipping somewhat more steeply towards the hinterland than the décollement zone itself (Fig. 24b). After the reversal of shear sense (Fig. 24d), the largest and smallest instantaneous stretching axes swapped, implying that the foliation, which had been in the extensional field (Fig. 24c), was now in the new shortening field of the instantaneous strain ellipse (Fig. 24e). Hence, the situation was similar to that of having a shear zone cutting a more steeply dipping foliation.

Examples of folds developed within an extensional detachment in gneiss from northwestern Toftøy Island in the Øygarden Complex in western Norway (Fig. $23 \mathrm{~b}-\mathrm{c})$ are shown in Fig. 25. Folds localised at or ahead of crests of boudins, tectonic lenses or earlier packages of folds (e.g. Figs. 22h-i and 25a-b) and above extensional shear bands (Fig. 25c) are strikingly similar to those developed in analogue models (Fig. 22a-g). In areas of high shear strain, the axes of early-formed folds have been rotated into parallelism with the maximum elongation direction, creating folds with opposite vergence and sheath folds (Fig. 25d). Extension resulting from normal displacement along secondary shear bands is accommodated by shortening elsewhere along the displaced layer (Fig. 25e).

A similar, reactivated thrust origin has been established for other extensional detachments in the Scandinavian Caledonides (Osmundsen and Andersen, 1994; Rykkelid and Andresen, 1994; Wennberg, 1996; Andersen, 1998). Normal slip on the pre-existing foliation and formation of reverse shear bands and NW-verging folds has been noted from the Kvamshesten Detachment, West Norway (Fig. 23) by Osmundsen and Andersen (1994), as illustrated in Fig. $24 \mathrm{f}-\mathrm{h}$.

\subsection{The Bremer Bay area, Albany Mobile Belt, Western Australia}

The Bremer Bay area of the eastern Albany Mobile Belt in Western Australia (Fig. 26) contains folds, shear zones and boudins developed in granulite facies gneiss during NW-SE extension. Extension is interpreted as resulting from collapse following crustal thickening and NW-directed thrusting onto the Archaean Yilgarn craton during oblique convergence with the Mawson Craton of East Antarctica (Harris, 1993, 1995) at ca. 1.2 Ga (Black et al., 1992). Structures formed during collapse and basic dykes and pegmatites intruded during this extensional stage are subsequently overprinted by a steeply dipping, NE-striking cleavage, indicating a return to NW-SE shortening.

The initially shallow dipping gneissic foliation parallel to compositional layering in tonalitic and intermediate gneiss and mafic granulite is folded by open, upright antiforms above listric normal shear zones. The antiform at location A in Fig. 27a refolds isoclinal recumbent folds developed in an earlier period of thrusting (location B in Fig. 27a). Extensional folding during displacement on a listric shear zone is equivalent to the model of Braun et al. (1994) shown in Fig. 5a in which there is no friction along the basal shear zone. Reduction of friction in the migmatitic gneiss at Bremer Bay may be due to the presence of melt that subsequently crystallised to form pyroxene-bearing pegmatites and mafic dykes along the shear zone (location C in Fig. 27a).

The interaction of normal shear zones and boudins has also produced several styles of folds. Gneissic foliation is drawn into normal shear zones associated with foliation boudinage with both normal and reverse senses of drag (locations A and B in Fig. 27b). Foliations between two normal shear zones are backrotated (location C in Fig. 27b), forming upright folds such as at location D in Fig. 27b. Open, upright folds are also formed due to necking and boudinage at wavelengths of tens of metres (e.g location A in Fig. 27c) to tens of centimetres (e.g. Fig. 27d). An extensional origin for the larger boudin-related folds would not be apparent except for the excellent exposure in sea cliffs in which one can clearly see synforms directly beneath antiforms (below and above boudins respectively) and folding into boudin necks. Folds (Fig. 27c) are also formed by tilting due to displacement along 
(location B), and back-rotation between (location C), extensional shear zones.

SE-verging folds with curved axial surfaces are also formed in broad zones of ductile flow, such as in Fig. 27e, that resemble folds formed in centrifuge models (e.g. locations A in Fig. 21c-d).

\subsection{The Ruby Mountains of Nevada}

Structures in the Ruby Mountains metamorphic complex from the Basin and Range Province, Nevada (Fig. 28a), have been interpreted by MacCready et al. (1997) as the result of flow during large-magnitude extension of the whole crust. These authors document a prolonged extensional event (following pre-metamorphic thrusting) that has led to the exhumation of mid-crustal metasedimentary rocks, migmatites and intrusives situated beneath a kilometre-thick, mylonitic extensional shear zone. Although initial folding took place in the Late Cretaceous (based on relationships with synkinematic leucogranites and migmatites), there has been substantial overprinting in a $>1-\mathrm{km}$-thick zone of protomylonitic gneisses in the Tertiary, during which older folds and fabrics have been amplified (McGrew et al., 2000).

Cross sections through the Ruby Mountains (Fig. $28 b-c)$ portray recumbent isoclinal folds with inverted limbs up to $10 \mathrm{~km}$ long similar in style and interpreted mode of formation to folds developed in centrifuge models (e.g. Fig. 21d-f). Both limbs of some recumbent folds (e.g. the Lamoille Canyon Nappe described by MacCready et al., 1997) have been thinned due to overprinting of mylonitic detachment shear zones. In Fig. 28b, the hinge of an isoclinal recumbent fold in dolomite marble has been highly attenuated forming pinch-and-swell structures and boudins (separated by up to approximately $1 \mathrm{~km}$ ). Folds within both the oppositely verging fold nappes and ductile shear zones are disharmonic. Upright folds coexist with, and locally refold, recumbent folds. The western uppermost corner of the quartzite unit in the core of the large, generally upright anticline (the Hidden Lakes Uplift, Fig. 28a-b) forms a westwards-verging recumbent fold. Again, the coexistence of fold styles is similar to that seen in centrifuge models described in Section 8.

\subsection{West Greenland}

An example of refolded, regional scale isoclinal folds and marked differences in deformation style between ductile middle-crustal rocks and overlying brittle crust comes from the Atâ Sund area of the Rinkian mobile belt, West Greenland (Fig. 29a). Amphibolite facies Palaeoproterozoic basement metasediments, metavolcanics, granite and othogneiss deformed by recumbent folds with overturned limbs $12 \mathrm{~km}$ or more in length have been refolded by the regional-scale Talorssuit dome and rim synclines (Escher and Pulvertaft, 1976; Grocott et al., 1987), as portrayed in Fig. 29b-c. The noncylindrical geometry of folds and existence of an intense NW-SE oriented sub-horizontal extension lineation led Grocott et al. (1987) to propose that recumbent folds formed within a sub-horizontal shear regime.

Although an overlying Karrat Group supracrustal sequence was deformed along with basement gneisses, it does not display the extensive recumbent folding of the basement gneisses. The Karrat Group has only been deformed by the late domes. Escher and Pulvertaft (1976) contend that the recumbent folds in basement gneiss were developed after deposition of the sedimentary sequence as basic dykes and sheets have

Fig. 24. (a) Profile through the northwestern margin of the Jotun Nappe, South Norway (see Fig. 23c for location). The Jotun Nappe was thrust several hundreds of kilometres to the SE, but reactivation of the underlying décollement zone as an extensional detachment produced large-scale folds with NW vergence. $(b-e)$ Explanation of folds in the décollement zone of the Caledonides in southern Norway. Caledonian thrusting (b) caused foliation and layering to be in the extensional field of the strain ellipse (c) during SE-directed thrust transport. Reversal of shear sense during extensional collapse (d) caused contraction and folding of the foliation and layering which lay in the contractional field of this second event $(\mathrm{e})$. ( $\mathrm{f}-\mathrm{h})$ Schematic cross sections showing formation of extensional detachments and related folds in the Kvamshesten Detachment, West Norway (see Fig. 23 for location). After Osmundsen and Andersen (1994). Cross sections (f-g) represent a crustal section several kilometres thick. (f) NW-dipping foliations (inherited from the previous SE-directed thrusting event) parallel potential slip lines and undergo normal reactivation. (g) Folding of the pre-existing foliation due to displacement on reverse shear bands during continued normal displacement on extensional detachments. (h) Detail from (g) showing mesoscopic folding along reverse shear bands during continued normal slip along preexisting foliation. 
intruded both and dykes have been subsequently folded in the basement. Boudinage of competent basic intrusive layers indicating horizontal extension is shown by these authors to be synchronous with recumbent folding. Normal ductile shear zones dis- place both limbs of recumbent folds (Escher and Pulvertaft, 1976, Fig 111), indicating continued horizontal extension after recumbent folding. A major normal ductile shear zone is located at the gneiss-metasediment contact (Grocott et al., 1987).

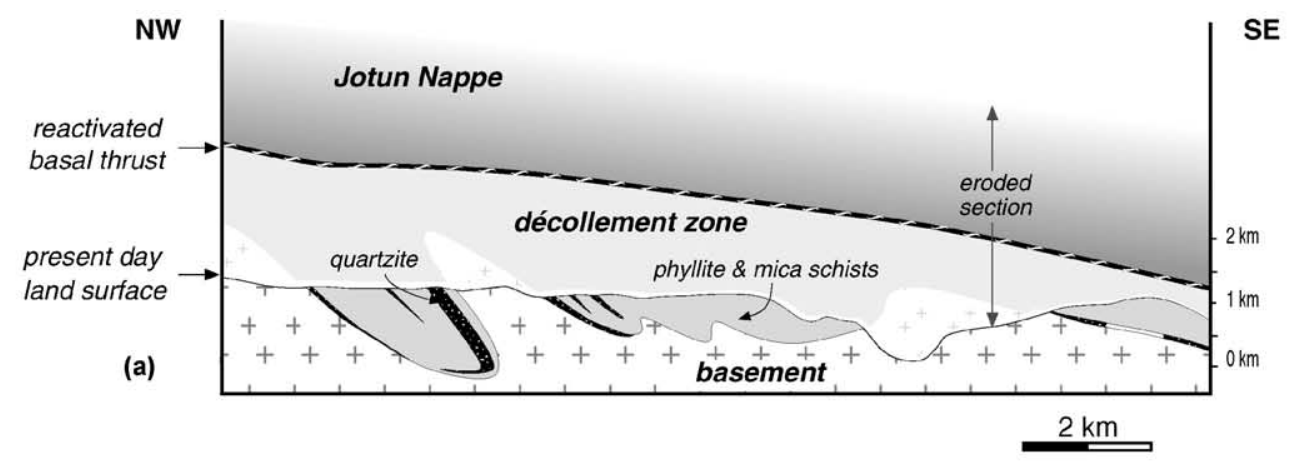

(b)

NW

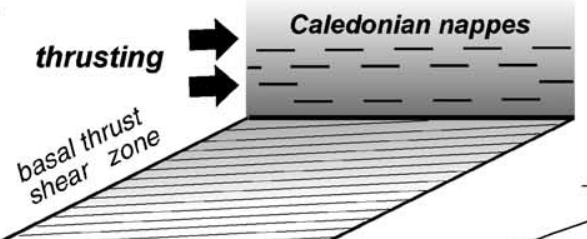

SE

NW
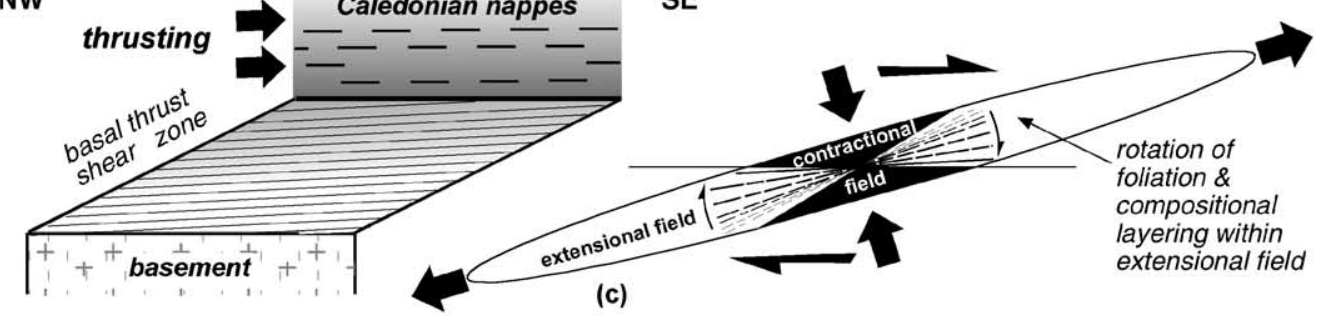

SE

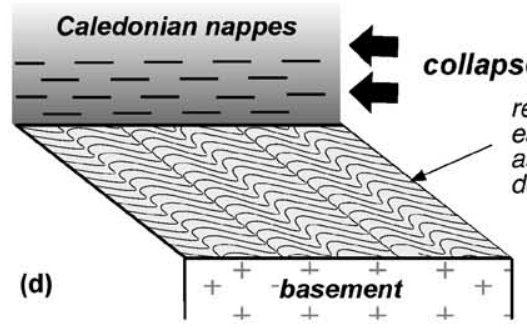

reactivation of earlier thrust zone as an extensional décollement

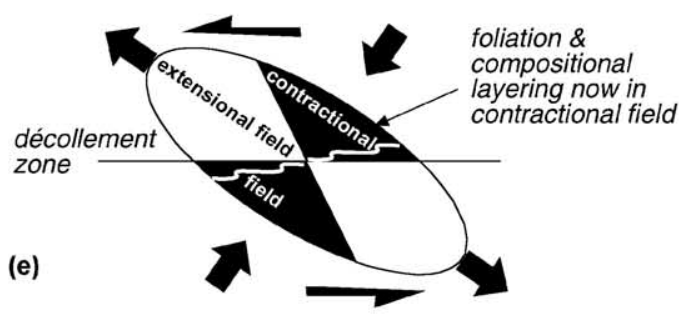

NW

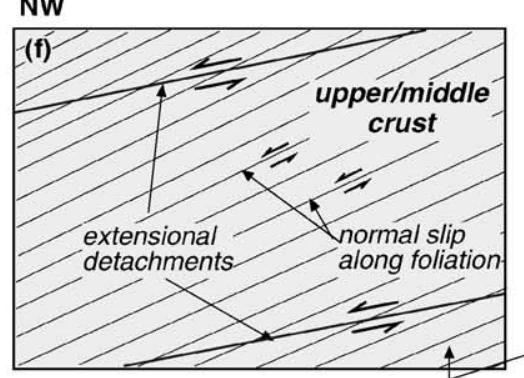

upper/middle crust

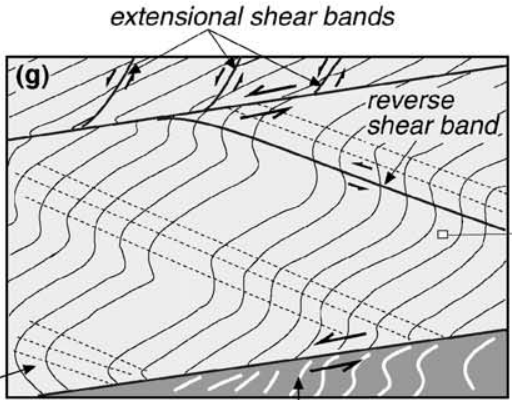

eclogite-bearing lower crust

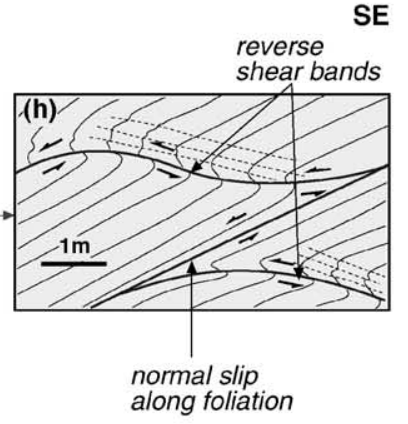



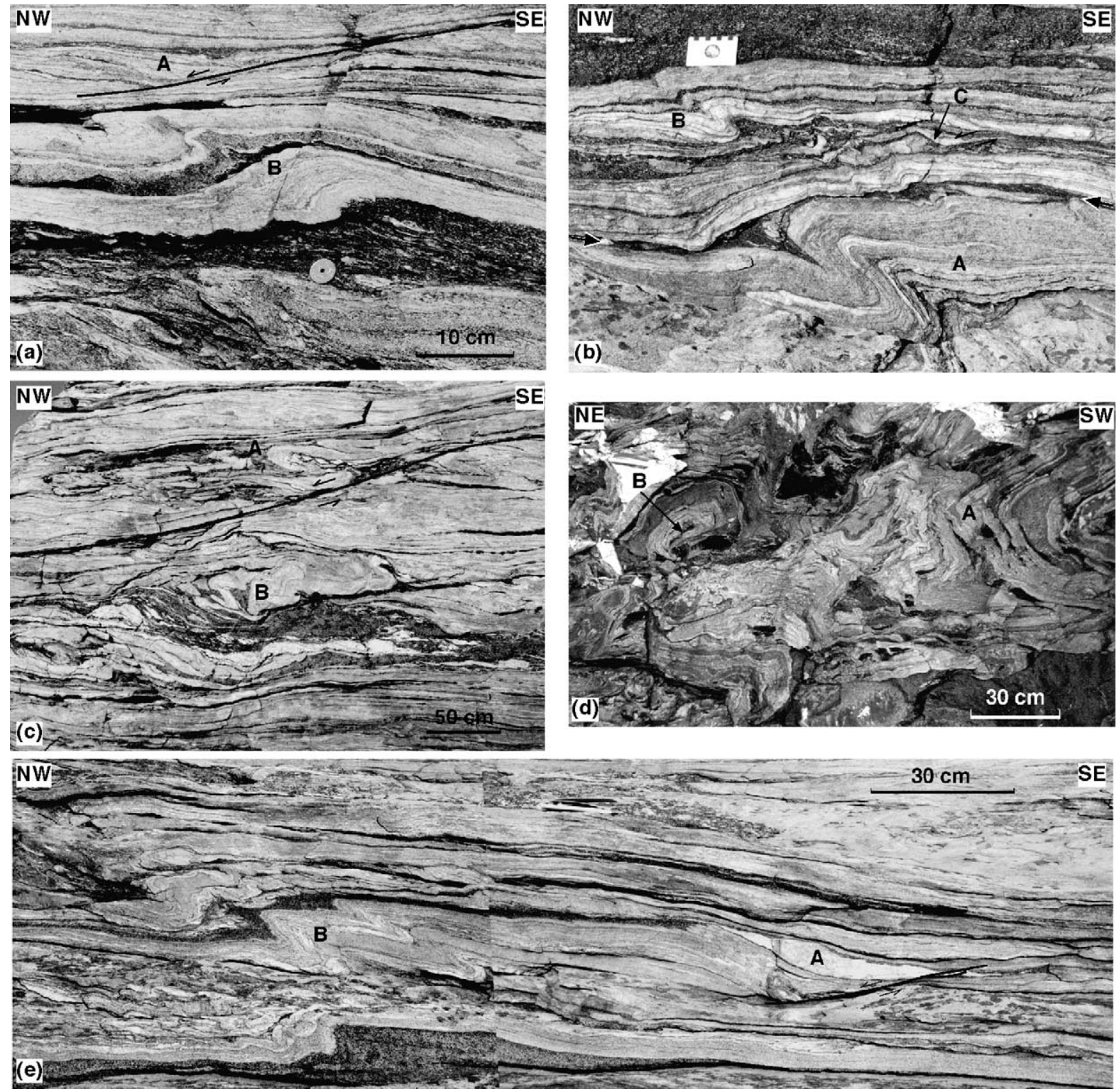

Fig. 25. Folding and development of extensional shear bands in cross sections through an extensional detachment in gneisses of the Øygarden Complex (see Fig. 23 for location). Sections $(\mathrm{a}-\mathrm{c})$ and (e) are parallel to the transport direction; section (d) is oriented perpendicular to the transport direction. (a) Upward tightening and overturning of folds in middle layers (B), with displacement of upper layers (A) along an extensional shear band. (b) An extensional detachment (arrowed) cuts across and truncates overturned folds (A). Folds at B develop above the inclined surface as seen in clay models in Fig. 18g. Layers are back-rotated at C between minor extensional shear bands. (c) Folds at A develop above an extensional shear band similar to structures seen in centrifuge models (e.g. Fig. 22e-f). Note complex refolding of isoclinal folds at B. (d) Tight (A) to isoclinal folds with axes parallel to the transport direction and sheath folds (B). (e) Partitioning of deformation into areas of localised extension and contraction. Drag and back-rotation of layer above an extensional shear band occurs at A, whereas at B layers are folded about NW-verging folds. 

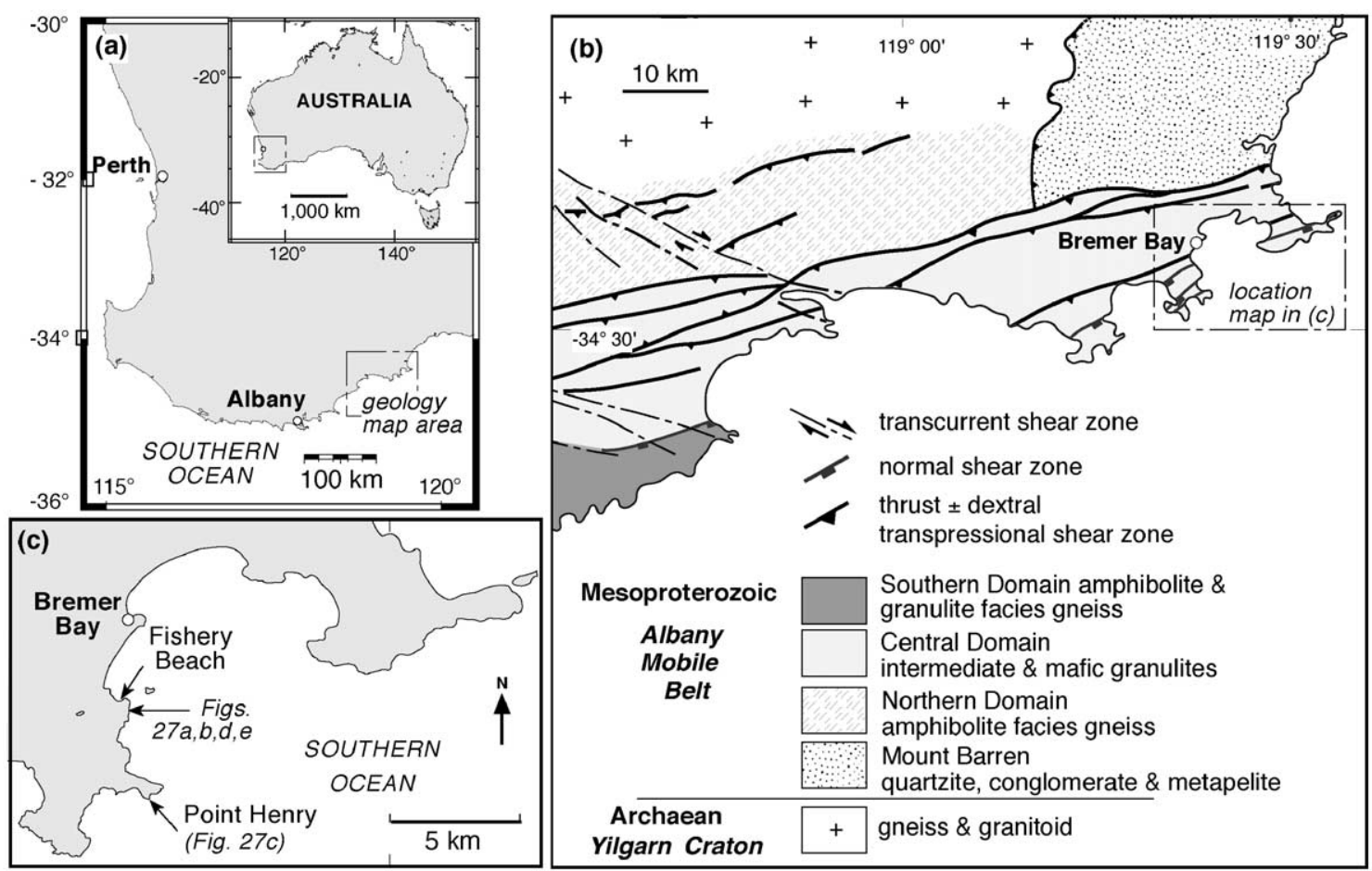

Fig. 26. Location and simplified geology maps of the eastern Albany Mobile Belt, Western Australia. Sites of photographs in Fig. 27 are shown in (c).

Grocott et al. (1987) consider that late doming (as seen in Fig. 29c) is likely to be due to gravitydriven diapiric uplift of the less-dense basement. Our models suggest that domal uplift may be due to, or accentuated by, isostatic upwelling during lithospheric extension.

Such extreme differences in structural style between the contemporaneously deformed basement and cover sequences are hard to envisage in a regional thrust setting. They are, however, seen in our centrifuge rift models (Fig. 21e-f). The upper crustal layers in these models have only undergone warping (forming a depression that would correspond to a broad sedimentary basin in nature), whereas the underlying ductile layers have been folded into recumbent folds during rifting.

\subsection{The Archaean Napier Complex, East Antarctica}

The Archaean Napier Complex of East Antarctica (Fig. 30a) provides an example of folding of lower crustal rocks in an extensional tectonic setting. The Napier Complex is one of the highest temperature (ca. $1000{ }^{\circ} \mathrm{C}$ ) exposed granulite terranes in the world (Mezger, 1992). High temperature metamorphism is synchronous with two deformation events $\left(D_{1}\right.$ and $\left.\mathrm{D}_{2}\right)$. $\mathrm{D}_{1}(3072 \mathrm{Ma})$ resulted in isoclinal recumbent folding of compositional layering at the centimetre to kilometre scale with extreme limb attenuation and the development of a transposed gneissic layering (Black and James, 1983; Sandiford and Wilson, 1984; Harley and Black, 1987). Examples of folds in granulite facies gneisses (described by Sandiford, 1989) are shown in Fig. 30b. These folds were interpreted by Sandiford and Wilson (1984) to have been formed with sub-horizontal axial surfaces and that their present orientation is due to refolding. Folds are locally associated with ductile shear zones referred to by Sandiford and Wilson (1984) as 'tectonic slides'. Exceptionally high extensional strains of $\mathrm{X} / \mathrm{Y} / \mathrm{Z}=400: 200$ : 1 (with a horizontal maximum extension direction) have been deduced by 

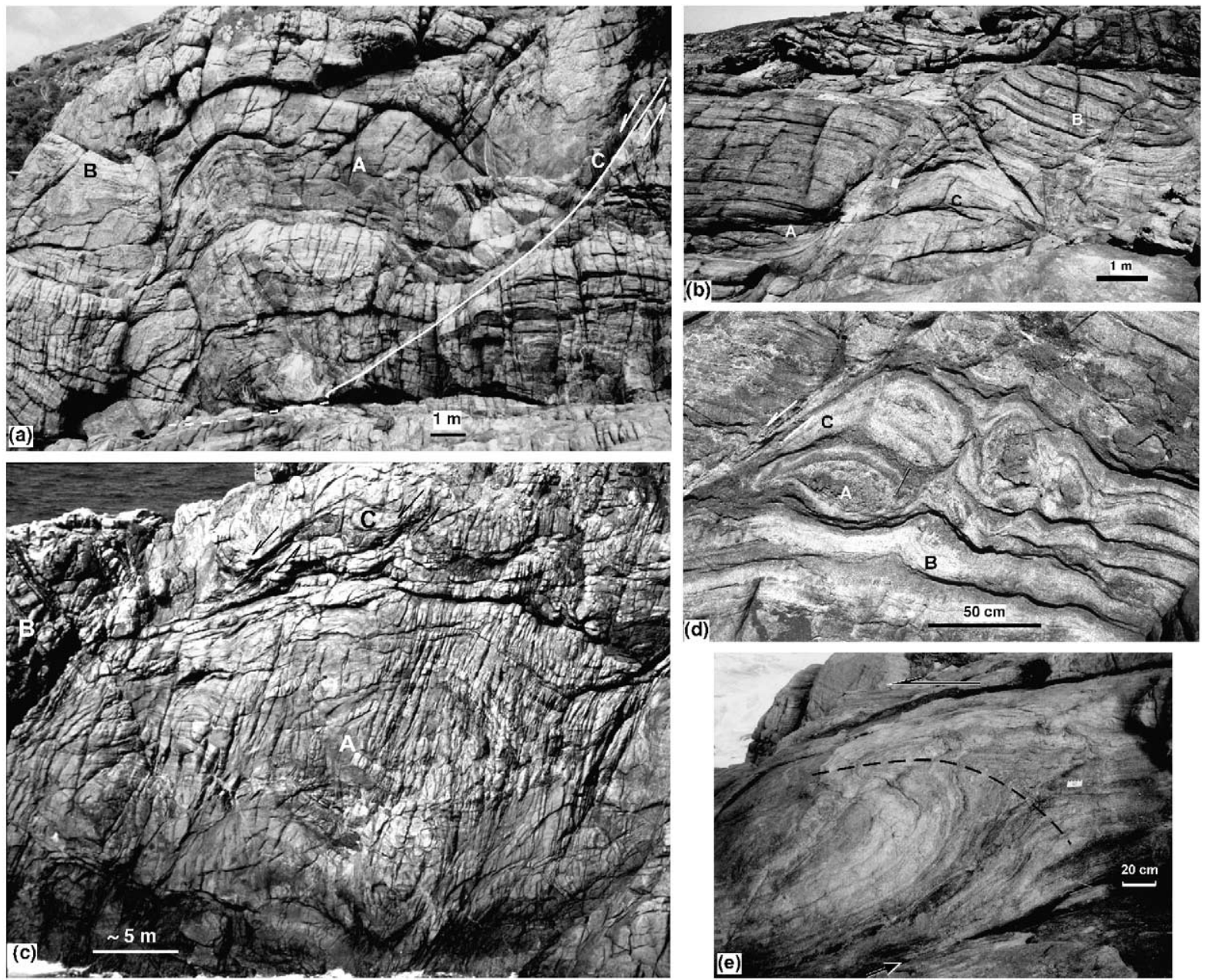

Fig. 27. Examples of folding associated with normal ductile shear zones and boudinage during NW-SE extension in granulite facies gneiss (Bremer Bay, Albany Mobile Belt, Western Australia). These structures are overprinted by a weak, steeply SW-dipping cleavage formed during subsequent horizontal contraction that controls the orientation of late joints. Note that All photos viewed looking SW, see Fig. 26 for locations. (a) Open, upright antiform (A) developed above a listric normal shear zone (white line). This antiform deforms SW-verging isoclinal folds (B) that in turn fold early recumbent isoclinal folds. The normal shear zone is intruded by pegmatites (e.g. at C) and mafic dykes. (b) Cliff face showing folds associated with a large boudin at A. Layers at B have been rotated to steep dips during displacement on a listric normal shear zone. Open folds at $\mathrm{C}$ have developed between two normal shear zones. An extensional origin for these folds would not be so apparent if structures were to be viewed on sub-horizontal outcrop surfaces through them - changes in dip could easily be misinterpreted as indicating NW-SE contraction. (c) Left of centre, foliation boudinage is combined with normal displacement along a ductile shear zone. Note folds due to normal drag of layering at $\mathrm{A}$; the sense of drag changes along the structure to reverse drag higher up (such changes in drag are common in foliation boudinage, as shown diagrammatically in Fig. 9d). The block B has undergone a clockwise (i.e. back-) rotation between two normal shear zones. Note normal drag of foliation into the bounding shear zones in middle layers of block B, and formation of an open antiform in footwall layers at C. (d) Boudinage of mafic layers (e.g. A) has produced localised folds in ductile tonalitic gneiss (e.g. at B). Note folds formed by drag of boudin and layering into a crosscutting normal shear zone at C. (e) SW-overturned antiform with curved axial surface. Note planar basal layer (above an extensional detachment, indicated by solid arrow) and progressive tightening upward. This style is similar to that seen in folds developed during flow of ductile layers in centrifuge experiments (e.g. location A in Fig. 21c-d). 


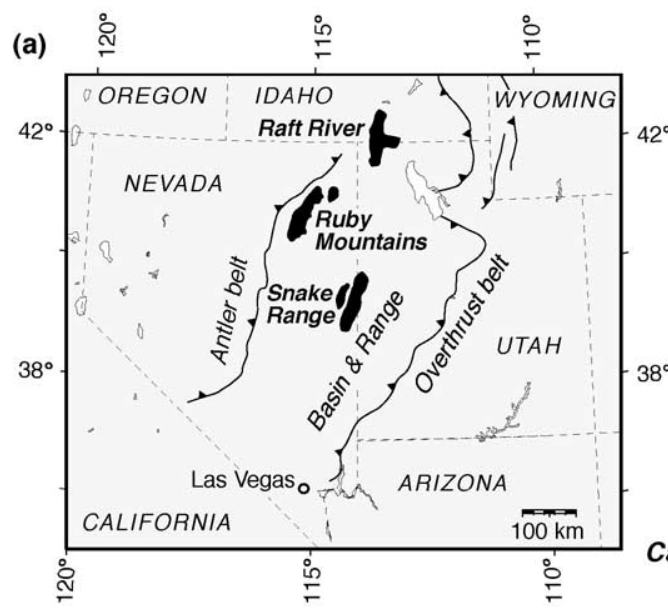

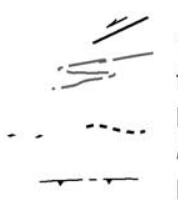

Quaternary (\& Tertiary?) late Eocene

Devonian

Devonian to Ordovician Ordovician

Ordovician \& Cambrian

Cambrian Cambrian \& Neoproterozoic normal fault form of upper nappe low angle normal (detachment) fault: position known, inferred pre-metamorphic thrust fault

alluvium \& undefined leucogranite orthogneiss calcite-dolomite marble dolomite marble quartzite calcite marble \& calc-silicate paragneiss dolomite marble quartzite \& pelitic schist

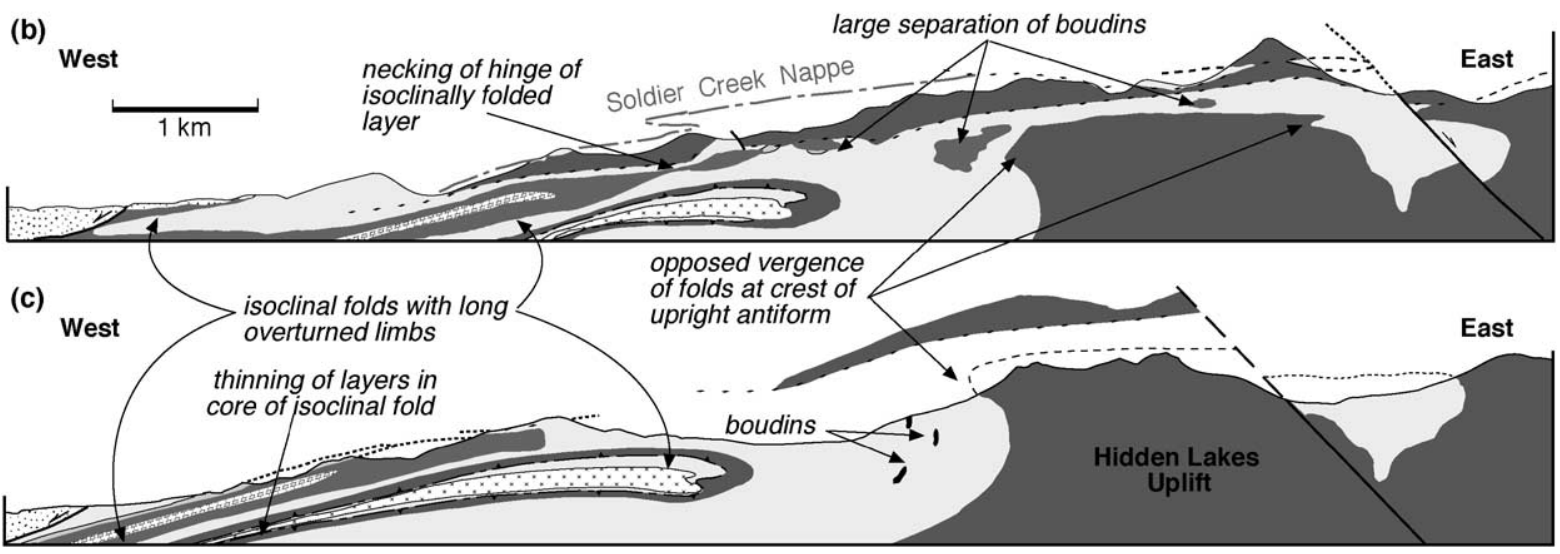

Fig. 28. Regional-scale folds in the Ruby Mountains, Nevada, interpreted by MacCready et al. (1997) to result from lower crustal flow during lithospheric extension. (a) Location map highlighting (in black) the Ruby Mountains and other major metamorphic complexes in the Basin and Range Province. Modified after Malavieille (1987b). (b-c) Sections through the Ruby Mountains (after MacCready et al., 1997). Note largescale recumbent isoclinal folds with thinned limbs, boudinage of the dolomite marble layers and the antiformal Hidden Lakes Uplift.

Sandiford and Wilson (1984) from boudinage of ultramafic layers during $\mathrm{D}_{1}$. $\mathrm{D}_{1}$ structures are refolded by recumbent to reclined folds on the mesoto macroscopic scale during continued high-grade metamorphism without significant crustal thickening in $\mathrm{D}_{2}$ (Sandiford and Wilson, 1984; Harley and Black, 1987).

The Napier Complex has undergone a long (ca. 2000 m.y.) lower crustal residence time, records a counterclockwise prograde $P-T-t$ path (Motoyoshi and Hensen, 1989; Harley and Hensen, 1990) and a near isobaric cooling path (Sandiford and Wilson, 1984; Harley and Hensen, 1990). An extensional tectonic setting for the early high-temperature metamorphism of the Napier Complex (and hence $\mathrm{D}_{1}$ and $\mathrm{D}_{2}$ folding) is therefore indicated (Motoyoshi and Hensen, 1989; Harley et al., 1990; Mezger, 1992). Near isobaric heating and cooling paths could occur in and above low-angle detachment zones formed in asymmetric simple shear rift models in normal thickness crust (Sandiford and Powell, 1986). Deformation is thought to have occurred at the base of a $30-\mathrm{km}-$ thick continental crust, with high heat flow and abundant magmatic intrusions (Mezger, 1992; Harley and Hensen, 1990). Mafic and ultramafic dykes intruded at $>2900$ Ma (Harley, 1985; Harley and 

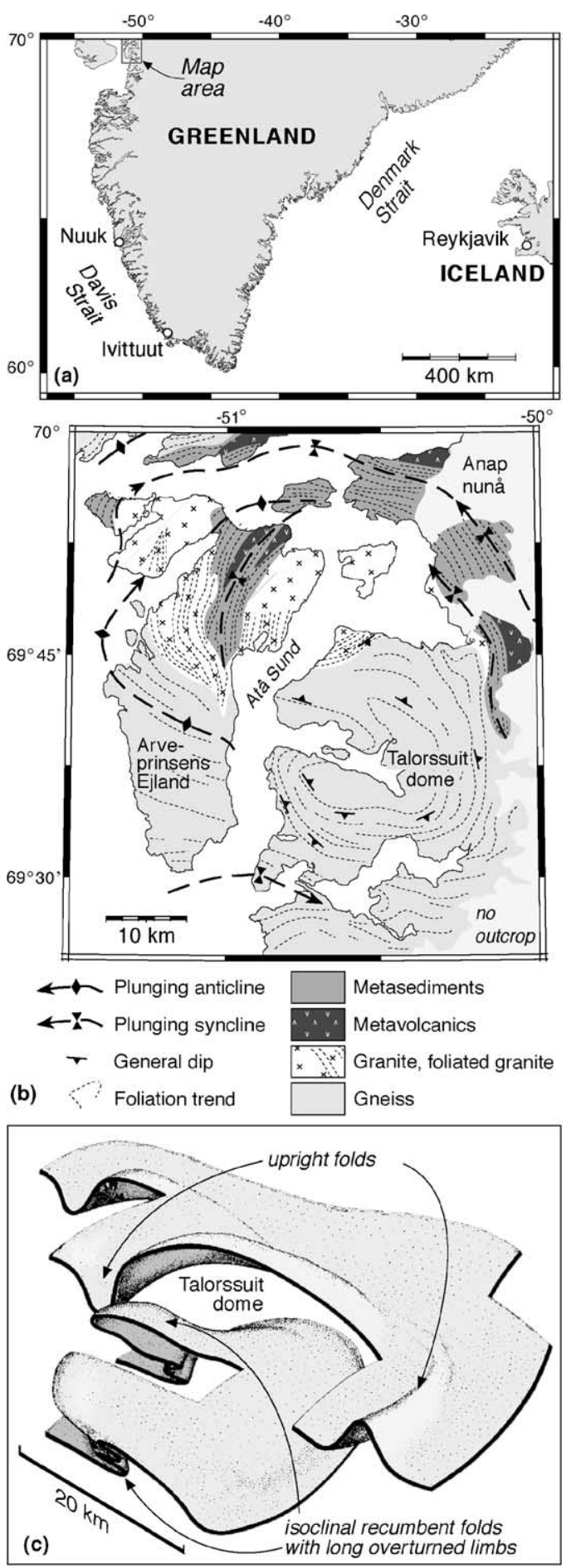

Black, 1987; Harley and Hensen, 1990; Mezger, 1992). An alternative model of thickening of continental crust by thrusting was proposed by Ellis (1987), who postulated the existence of an early high pressure metamorphic event and notes the lack of abundant mafic magmatism. An extensional model was, however, favoured by Mezger (1992) based on the following:

(i) An apparent lack of decompression textures. Breakdown reactions from high-pressure to low-pressure assemblages should be present if the model of Ellis (1987) for crustal thickening and rapid, synorogenic uplift were correct.

(ii) Arguments against early high-pressure metamorphism. Depletion of heavy rare earth elements in felsic intrusives (interpreted by Ellis, 1987, as requiring residual garnet and hence early high pressures) is thought by Mezger (1992) to be inconclusive as it could be due to the prior depletion of the source.

(iii) Examples illustrating that crustal extension may not always produce mafic magmatism, thus explaining the apparent lack of $3.1 \mathrm{Ga}$ mafic intrusions.

It is interesting to note that Mezger (1992), whilst favouring an extensional model, suggests a possible transition to a minor compressional tectonic regime to form folds in high-grade gneiss. Centrifuge modelling results suggest that these folds could also have formed within an extensional tectonic setting, eliminating the need for a change in tectonic regime.

$\mathrm{D}_{1}$ and $\mathrm{D}_{2}$ structures were deformed by open upright folds and 1-10 km-scale domes and basins at ca. 2463 Ma during $\mathrm{D}_{3}$ at lower granulite to upper amphibolite facies (Black and James, 1983; Harley and Black, 1987). Steeply dipping, crosscutting $\mathrm{D}_{3}$ high strain zones are intruded by dykes (Sandiford and Wilson, 1984). From geobarometric studies, these authors suggest uplift of 5-10 km between $\mathrm{D}_{2}$ and $\mathrm{D}_{3}$, and without substantial crustal thickening in $\mathrm{D}_{3}$.

Fig. 29. The Talorssuit gneiss dome, Atâ Sund area, West Greenland. (a) Location of the Atâ Sund area. (b) Geological map. (c) Block diagram reconstruction of the Talorssuit gneiss dome beneath an extensional detachment. Note overturned limbs up to 10 $\mathrm{km}$ long of isoclinal recumbent folds that have been deformed by subsequent doming. Figs. $\mathrm{b}-\mathrm{c}$ modified after Escher and Pulvertaft (1976). 

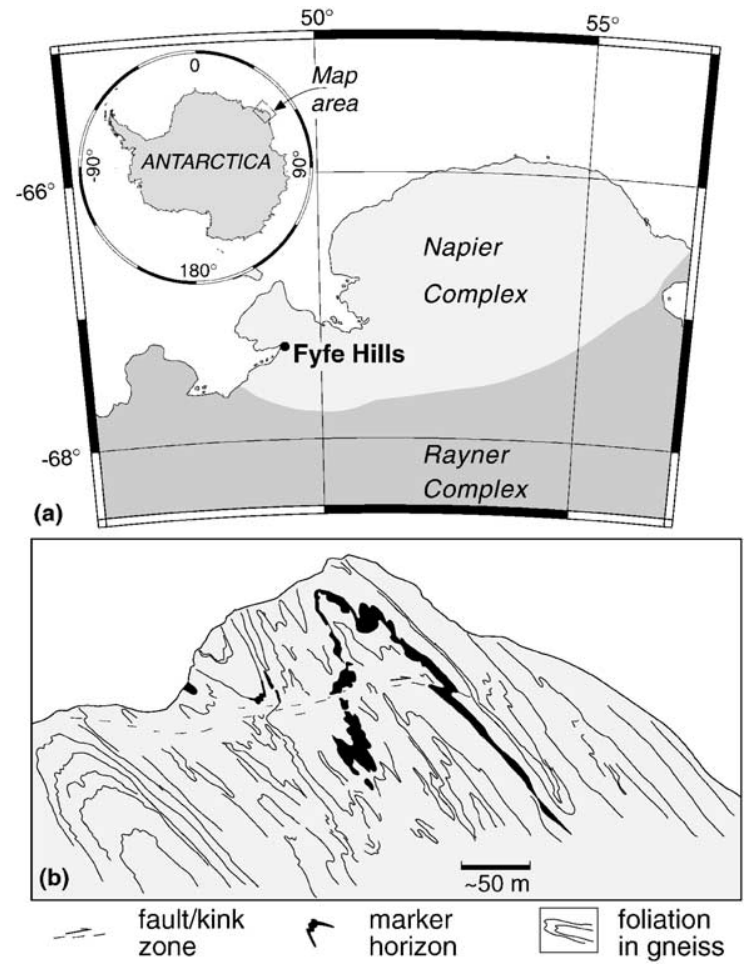

Fig. 30. Folding of granulite facies gneiss in an extensional tectonic setting in the Fyfe Hills area, Enderby Land, East Antarctica. (a) Position of Fyfe Hills in the Archaean Napier Complex. Modified after Harley et al. (1990). Inset shows map area. (b) Interpretation of a photograph (Sandiford, 1989, fig. 1) depicting isoclinal recumbent folds in granulite facies gneiss. Scale approximate. Sandiford (1989) and Sandiford and Wilson (1984) interpret these folds to have formed with sub-horizontal axial surfaces and that the present moderately dipping attitude of their axial surfaces is due to subsequent refolding.

They conclude that $\mathrm{D}_{3}$ structures were formed during differential vertical movements, and do not result from buckling due to horizontal contraction. Such late vertical movements are seen in centrifuge rift models, suggesting that $D_{1}$ to $D_{3}$ structures may all be due to stages of deformation related to lithospheric extension.

\subsection{Seward Peninsula in western Alaska}

The Kigluaik Mountains in the Seward Peninsula in western Alaska (Fig. 31a) provides another example of formation of recumbent isoclinal folds and their subsequent refolding by the Kigluaik dome (Fig. $31 \mathrm{~b}-\mathrm{c}$ ) during regional crustal extension (Amato et al., 1994 and Hannula et al., 1995). Hannula et al. (1995) document a continuous structural section, decreasing upwards in metamorphic grade. There is no evidence for duplication or the presence of highgrade rocks structurally above low-grade rocks that would indicate thrusting. They provide evidence that deformation took place during increasing metamorphic temperatures deep in the section synchronously with deformation at higher structural levels.

Abundant recumbent isoclinal folds have been described in gneisses up to granulite facies overlying the Kigluaik gneiss dome (Amato et al., 1994) and in intrusive bodies in the dome. An initially sub-horizontal foliation was developed in gneisses and recumbent folds formed in initially sub-vertical mafic intrusives during vertical shortening and horizontal extension (Fig. 32). Younger mafic dykes cut folds. Intrusions in the core of the Kigluaik gneiss dome are mantle-derived, and the overlying gneisses have undergone high-temperature metamorphism (Amato et al., 1994). The dome is interpreted by these authors to have formed by late-tectonic diapiric ascent during regional extension and lower crustal flow, deforming and doming structures in the overlying gneisses and schists (Fig. 32). Extension resulted in crustal thinning and the exhumation of these deep crustal rocks.

\section{Seismic imaging of extensional structures in the deep crust}

\subsection{Problems in seismic imaging of in situ structures} in high-grade rocks

It is not possible to completely determine the geological structure of complexly deformed regions of the deep crust from seismic data due to the physical properties of the rock types and the style of structures commonly present. This is well illustrated on a synthetic seismic section for isoclinally folded gneisses and mafic and felsic intrusives in the Kapuskasing Zone by Reston (1990). No reflections result where there is little velocity or density (i.e. acoustic impedance) contrast between lithologies, as is commonly the case in high-grade terrains (Reston, 1990). A network of shallowly dipping reflections and refractions forms where there is sufficient velocity and/or density contrast (Mooney and Meissner, 1992). This 


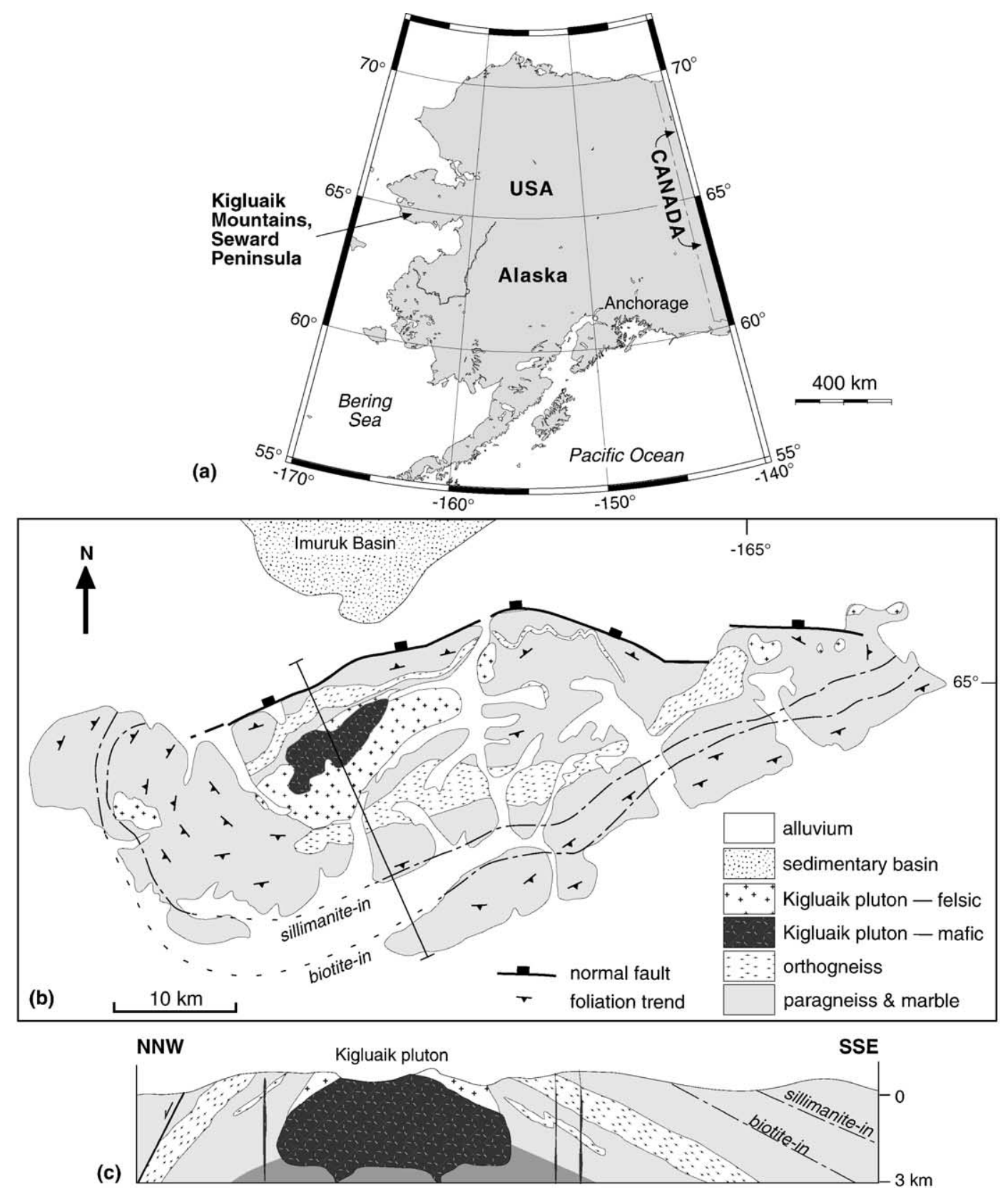

Fig. 31. Gneiss dome in the Kigluaik Mountains, western Alaska. (a) Location map. (b) Simplified geological map of the Kigluaik gneiss dome (after Amato et al., 1994). (c) Simplified cross section (compiled from sections by Amato et al., 1994).

still produces only a low resolution and distorted image of the in situ crust (Reston, 1990). Hinge regions of overturned to recumbent folds cannot be imaged (Reston, 1990; Long et al., 1996), so direct verification of folds formed during flow in the deep crust beneath known rifts by seismic imaging is not possible. It is important to realise that isoclinal recumbent fold closures, such as developed in the exten- 

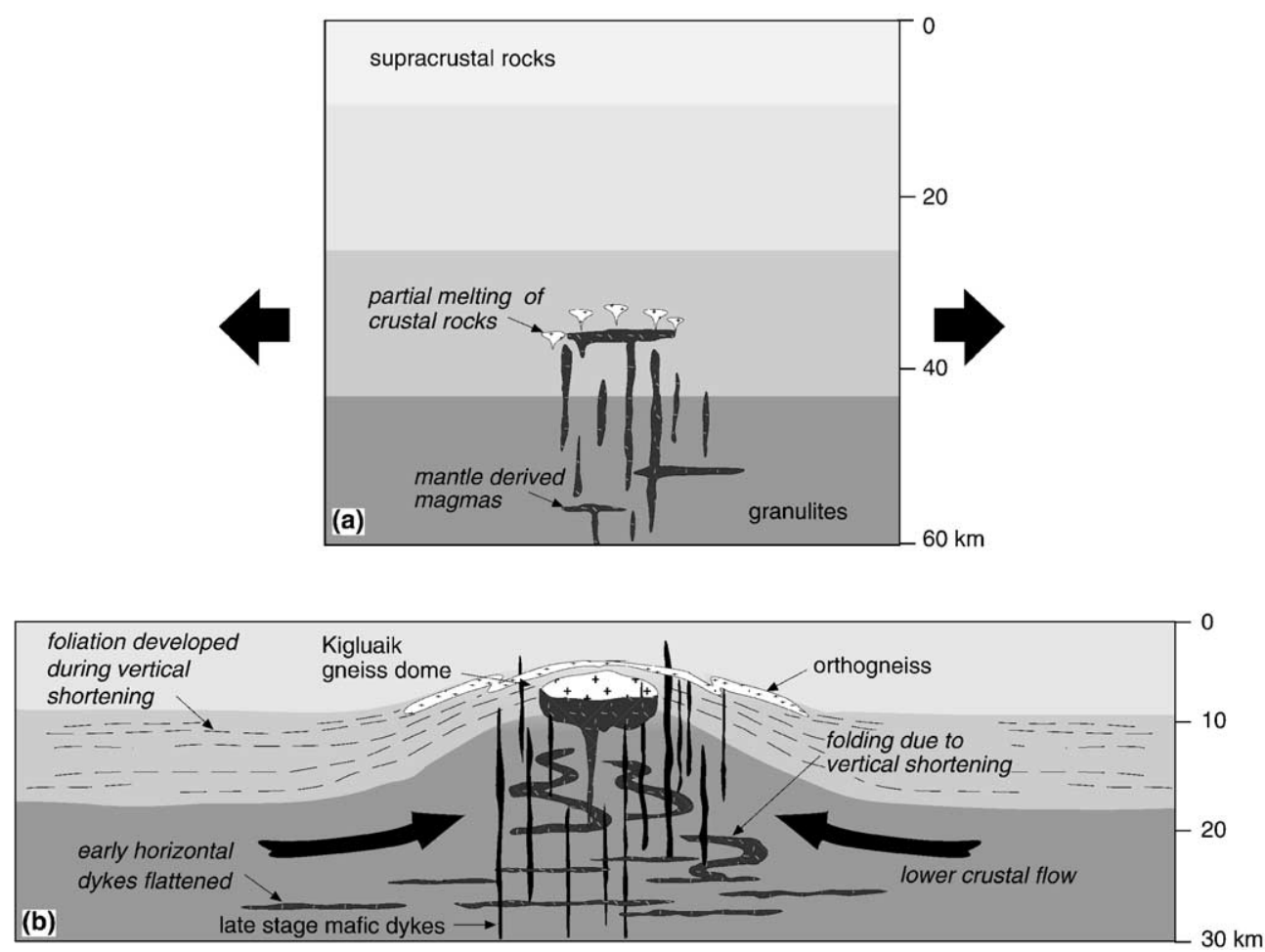

Fig. 32. Model of Amato et al. (1994) for the evolution of the Kigluaik gneiss dome involving extension of structurally thickened continental crust by lower crustal flow and diapiric uplift. (a) Schematic cross section at start of extension. (b) Exhumation of high-grade rocks and formation of the gneiss dome resulting from erosion, crustal thinning and diapirism. Note formation and folding of a sub-horizontal foliation in gneisses and recumbent folds of early sub-vertical dykes by vertical shortening during horizontal extension.

sional centrifuge models described above, or as seen in exhumed rocks that were deformed in extensional settings, will not be imaged on deep seismic profiles.

Problems are also encountered in interpreting the presence and nature of shear zones in the deep crust from seismic data (Mooney and Meissner, 1992). Ji et al. (1993) show that anisotropy as a result of fabric development in ductile shear zones can both enhance and decrease seismic reflectivity. They conclude that the discontinuity of seismic reflections thought to represent ductile shear zones in the lower crust is not necessarily indicative of the discontinuity of the shear zones, but may indicate changes in composition or metamorphic grade.

The above limitations in the seismic method are, of course, also true for the imaging of structures developed in contractional tectonic settings. One is, however, more likely to assume the existence of recumbent folds in a convergent orogen than in the ductile crust beneath rifts.

\subsection{Imaging of normal shear zones cutting the mantle}

Despite the problems noted in Section 10.1, reflections in the upper mantle on BIRPS deep seismic profiles offshore Britain have been interpreted as localised shear zones (Warner and McGeary, 1987; Klemperer, 1988; Reston, 1990, 1993). In some instances, the Moho is clearly displaced (e.g. Brun and Tron, 1993; Fig. 12a), producing rift geometries similar to the early stages of centrifuge models of Harris and Koyi (in press). Normal shear zones cutting lithospheric mantle may represent reactivation of previous sutures, such as in the offshore central Appalachians (Phinney, 1986), or have been initiated 
during lithospheric extension (Reston, 1993). Seismic data suggest that mantle shear zones flatten and die out or disappear upwards into the base of the crust so that strain is distributed in a wide zone of ductile deformation.

\section{Conclusions}

Folding in amphibolite and granulite facies rocks during rifting or orogenic collapse, or accompanying pluton emplacement, is seen to be a common phenomenon at all scales. An extensional tectonic setting for the formation of folds must therefore be considered in the study of high-grade gneiss terrains. It is likely that some medium- to high-grade terrains may have been incorrectly interpreted as having undergone regional shortening in a convergent margin setting by the failure to recognise one or more of the fold mechanisms outlined in this paper.

Formation of a flat-lying foliation and its subsequent folding may take place during progressive deformation in an extensional setting. Folds may occur by a wide range of mechanisms. An extensional origin is clear where folds develop due to displacement of layers by a steeper dipping normal shear zone, or by rollover or tightening with depth of listric normal shear zones. Folds are formed during boudinage of sub-horizontal competent layers in a more ductile matrix, at the outcrop to crustal scale. Refolded folds may form during lower crustal flow and subsequent doming in asymmetric rifts, and due to progressive overprinting during back-rotation between closely spaced normal or transcurrent ductile shear zones. Folding between shear zones during horizontal extension may explain the formation of folds with opposite vergence, the presence of pegmatites along the axial surfaces of folds and transposition of folds and pegmatites into a regional foliation. This paper has also shown that centrifuge analogue modelling has proved a valuable tool in developing an understanding of processes likely to take place in the deep crust.

Other fold mechanisms, such as folds developed within extensional shear zones, are not confined to an extensional setting, and determination of the tectonic environment in which they are formed is not obvious without recourse to regional tectonic or metamorphic arguments (e.g. pressure-temperature-time paths).

\section{Acknowledgements}

Centrifuge modelling was funded by the Swedish Institute (to Koyi and Harris) and from an Australian Research Council (ARC) Small Grant (to Harris). Koyi acknowledges funding from the Swedish Research Council (VR). Fieldwork by Harris in the Central Metasedimentary Belt, Québec, was carried out in collaboration with B. Rivard and L. Corriveau (funded by KWG Resources and the Sainte-Geneviève Group through the Industrial Partnership Program of the Geological Survey of Canada). Harris acknowledges funding for fieldwork in the Albany Mobile Belt and Leeuwin Complex from ARC Large and Small grants. Sabbatical leave at the University of Bergen and Uppsala University and fieldwork in Norway by Harris were funded by a University of Western Australia study leave grant. Prof. C. Talbot is thanked for discussions on fold mechanisms and advice on analogue modelling. D. Gray, P. Hudleston and K. Kobayashi are thanked for their helpful comments during the review of an earlier draft. Topographic location maps have been modified after maps downloaded from Geomar Online Map Creation http://www.aquarius.geomar.de/ omc/). This is Tectonics Special Research Centre publication number 173 .

\section{References}

Aerden, D.G.A.M., 1994. Kinematics of orogenic collapse in the Variscan Pyrenees deduced from microstructures in porphroblastic rocks from the Lys-Caillaouas massif. Tectonophysics $238,139-160$.

Alsop, G.I., 1991. Gravitational collapse and extension along a midcrustal detachment: the Lough Derg Slide, northwest Ireland. Geol. Mag. 128, 345-354.

Amato, J.M., Wright, J.E., Gans, P.B., Miller, E.L., 1994. Magmatically induced metamorphism and deformation in the Kigluaik gneiss dome, Seward Peninsula, Alaska. Tectonics 13, 515-527.

Andersen, T.B., 1998. Extensional tectonics in the Caledonides of southern Norway, an overview. Tectonophysics 285, 333-351.

Andersen, T.B., Jamtveit, B., 1990. Uplift of deep crust during extensional collapse: a model based on field studies in the SognSunnfjord region of Western Norway. Tectonics 9, 1097-1111.

Andersen, T.B., Osmundsen, P.T., Jolivet, L., 1994. Deep crustal fabrics and a model for the extensional collapse of the southwest Norwegian Caledonides. J. Struct. Geol. 16, 1191-1203.

Avigad, D., Garfunkel, Z., 1991. Uplift and exhumation of highpressure metamorphic terrains: the example of the Cycladic blueschist belt (Aegean Sea). Tectonophysics 188, 357-372. 
Avramchev, L., Piché, G., 1981. Carte des gîtes minéraux du Québec, région de Laurentie-Saguenay (DPV-809). Ministère de l'Energie et des Ressources du Québec.

Becker, A., 1995. Conical drag folds as kinematic indicators for strike-slip fault motion. J. Struct. Geol. 17, 1497-1506.

Bell, T.H., Hammond, R.E., 1984. On the internal geometry of mylonite zones. J. Geol. 92, 667-686.

Belousov, V.V., 1965. The problem of the origin of folding. In: Sorskiy, A.A., Belousov, V.V. (Eds.), Folded Deformations in the Earth's Crust, Their Types and Origins. Israel Program for Scientific Translations (Translated from Russian), Jerusalem, pp. $1-6$.

Berthé, D., Brun, J.-P., 1980. Evolution of folds during progressive shear in the South Amorican Shear Zone, France. J. Struct. Geol. 2, 127-133.

Bertotti, G., Podladchikov, Y., Daehler, A., 2000. Dynamic link between the level of ductile crustal flow and style of normal faulting of brittle crust. Tectonophysics 320, 195-218.

Bjørnerud, M., 1989. Mathematical model for folding of layering near rigid objects in shear deformation. J. Struct. Geol. 11, 245254.

Black, L.P., James, P.R., 1983. Geological history of the Archaean Napier Complex of Enderby Land. In: Oliver, R.L., James, P.R., Jago, J.B. (Eds.), Antarctic Geoscience. Australian Academy of Science, Canberra, pp. 11-15.

Black, L.P., Harris, L.B., Delor, C.P., 1992. Reworking of Archaean and Early Proterozoic components during a progressive, Middle Proterozoic tectonothermal event in the Albany Mobile Belt, Western Australia. Precambrian Res. 59, 95-123.

Bons, P., 1999. Apparent extensional structures due to volume loss. Proc. Est. Acad. Sci., Geol. 48, 3-14.

Bradbury, H.J., Nolen-Hoeksema, R.C., 1985. The Lepontine Alps as an evolving metamorphic core complex during A-type subduction: evidence from heat flow, mineral cooling ages, and tectonic modelling. Tectonics 2, 187-211.

Braun, J., Batt, G.E., Scott, D.L., McQueen, H., Beasley, R., 1994. A simple kinematic model for crustal deformation along twoand three-dimensional listric normal faults derived from scaled laboratory experiments. J. Struct. Geol. 16, 1477-1490.

Brun, J.-P., Choukroune, P., 1981. Déformation progressive et structures crustales. Rev. Géol. Dyn. Géogr. Phys. 23, $177-$ 193.

Brun, J.-P., Merle, O., 1988. Experiments on folding in spreadinggliding nappes. Tectonophysics $145,129-139$.

Brun, J.-P., Tron, V., 1993. Development of the North Viking Graben; inferences from laboratory modelling. In: Cloetingh, S., Sassi, W., Horvath, F., Puigdefabregas, C. (Eds.), Basin Analysis and Dynamics of Sedimentary Basin Evolution. Sediment. Geol., vol. 86, pp. 31-51.

Brun, J.-P., Van Den Driessche, J., 1994. Extensional gneiss domes and detachment fault systems: structure and kinematics. Bull. Soc. Géol. Fr. 165, 519-530.

Burchfiel, B.C., Royden, L.H., 1985. North-south extension within the convergent Himalayan region. Geology 13, 679-682.

Burchfiel, B.C., Zhiliang, C., Hodges, K.V., Yuping, L., Royden, L.H., Changrong, D., Jiene, X., 1992. The South Tibetan detachment system, Himalayan Orogen: extension contemporane- ous with and parallel to shortening in a collisional mountain belt. Spec. Pap.-Geol. Soc. Am.

Burg, J.-P., 1991. Syn-migmatization way-up criteria. J. Struct. Geol. 13, 617-623.

Burg, J.-P., Ford, M., 1997. Orogeny through time: an overview. In: Burg, J.P., Ford, M. (Eds.), Orogeny through Time. Geol. Soc. London, Spec. Publ., vol. 121, pp. 1-17.

Burg, J.-P., Harris, L.B., 1982. Tension fractures and boudinage oblique to the maximum extension direction: an analogy with Lüders Bands. Tectonophysics 83, 347-363.

Burg, J.-P., Vanderhaeghe, O., 1993. Structures and way-up criteria in migmatites, with application to the Velay Dome (French Massif Central). J. Struct. Geol. 15, 1293-1301.

Burg, J.-P., Brunel, M., Gapais, D., Chen, G.M., Liu, G.H., 1984. Deformation of leucogranites of the crystalline Main Central Sheet in southern Tibet (China). J. Struct. Geol. 6, 535-542.

Burg, J.-P., Chaudhry, M.N., Ghazanfar, M., Anczkiewicz, R., Spencer, D., 1996. Structural evidence for back sliding of the Kohistan arc in the collisional system of northwest Pakistan. Geology 24, 739-742.

Caby, R., Pêcher, A., Le Fort, P., 1983. Le grand chevauchement central himalayen: nouvelles données sur la metamorphisme inverse à la base de la Dalle du Tibet. Rév. Geol. Dyn. Géogr. Phys. 24, 89-100.

Carey, S.W., 1976. The expanding Earth. Development in Geotectonics 10. Elsevier, Amsterdam.

Carey, S.W., 1988. Theories of the Earth and Universe: A History of Dogma in the Earth Sciences. Stanford University Press, Stanford.

Carmignani, L., Decandia, F.A., Fantozzi, P.L., Lazzarotto, A., Liotta, D., Meccheri, M., 1994. Tertiary extensional tectonics in Tuscany (Northern Appennines, Italy). Tectonophysics 238, 295-315.

Carosi, R., Cerbai, N., Montomoli, C., 1996. The F2 folds in the Verrucano as records of extensional tectonics in the Northern Apennines (Italy). C. R. Acad. Sci. Paris (Sér. IIa) 322, 773-780.

Chauvet, A., Séranne, M., 1994. Extension-parallel folding in the Scandinavian Caledonides: implications for late-orogenic processes. Tectonophysics 238, 31-54.

Cloos, E., 1947. Boudinage. Trans.-Am. Geophys. Union 28, 626632.

Cobbold, P.R., Quinquis, H., 1980. Development of sheath folds in shear regimes. J. Struct. Geol. 2, 119-126.

Coney, P.J., 1980. Cordilleran metamorphic core complexes: an overview. In: Crittenden, M.D., Coney, P.J., Davis, G.H. (Eds.), Cordilleran Metamorphic Core Complexes. Geol. Soc. Am., Mem., vol. 153, pp. 7-31.

Cooke, A., Harris, L.B., 1987. Analogue modelling experiments during normal and oblique extension. Applied extension tectonics. Aust. Bur. Miner. Resour. Rec. 51, 116-124.

Corriveau, L., Jourdain, V., 1993. Geology of the Lac Nominingue area, Québec (NTS 31J/6). Scale 1:50,000. Geol. Surv. Can., Open File, 2641.

Corriveau, L., van Breeman, O., 2000. Docking of the Central Metasedimentary Belt to Laurentia in Geon 12: evidence from the 1.17-1.16 Ga Chevreuil Intrusive Suite and host gneisses, Quebec. Can. J. Earth Sci. 37, 253-269.

Culshaw, N.G., Ketchum, J.W.F., Wodicka, N., Wallace, P., 1994. 
Deep ductile extension following thrusting in the southwestern Grenville Province, Ontario. Can. J. Earth Sci. 31, 160-175.

Culshaw, N.G., Jamieson, R.A., Ketchum, J.W.F., Wodicka, N., Corrigan, D., Reynolds, P.H., 1997. Transect across the northwestern Grenville orogen, Georgian Bay, Ontario: polystage convergence and extension in the lower orogenic crust. Tectonics 16, 966-982.

Dalmayrac, B., Molnar, P., 1981. Parallel thrust and normal faulting in Peru and constraints on the state of stress. Earth Planet. Sci. Lett. 55, 473-481.

Davis, M., Farber, DL., Wooden, J.L., Anderson, J.L., 1994. Conflicting tectonics? Contraction and extension at middle and upper crustal levels along the Cordilleran Late Jurassic arc, southeastern California. Geology 22, 247-250.

Decker, K., Peresson, H., 1996. Tertiary kinematics in the AlpineCarpathian-Pannonian system: links between thrusting, transorm faulting and crustal extension. In: Wessely, G., Liebl, W. (Eds.), Oil and Gas in Alpidic Thrustbelts and Basins of Central and Eastern Europe. EAGE Spec. Publ., vol. 5, pp. 69-77.

Dennis, A.J., Secor, D.T., 1990. On resolving shear directions in foliated rocks deformed by simple shear. Geol. Soc. Am. Bull. 102, 1257-1267.

Dewey, J.F., 1988. Extensional collapse of orogens. Tectonics 7, $1123-1139$.

Dirks, P.H.G.M., Zhang, J.S., Passchier, C.W., 1997. Exhumation of high-pressure granulites and the role of lower crustal advection in the North China Craton near Datong. J. Struct. Geol. 19, $1343-1358$.

Dixon, J.M., Summers, J.M., 1985. Recent developments in centrifuge modelling of tectonic processes: equipment, model construction techniques and rheology of model materials. J. Struct. Geol. 7, 83-102.

Docherty, C., Banda, E., 1995. Evidence for the eastward migration of the Alboran Sea based on regional subsidence analysis: a case for basin formation by delamination of the subcrustal lithosphere. Tectonics 14, 804-818.

Dula Jr., W.F., 1991. Geometric models of listric normal faults and rollover folds. AAPG Bull. 75, 1609-1625.

Duval, B.C., Cramez, C., Jackson, M.P.A., 1992. Raft tectonics in the Kwanza Basin, Angola. Mar. Pet. Geol. 9, 389-404.

Ellis, D.J., 1987. Origin and evolution of granulites in normal and thickened crust. Geology 15, 167-170.

Ellis, P.G., McClay, K.R., 1988. Listric extensional fault systems; results of analogue model experiments. Basin Res. 1, 55-70.

England, P., Houseman, G., 1989. Extension during continental convergence, with applications to the Tibetan Plateau. J. Geophys. Res. 94, $17561-17579$.

Escher, A., Pulvertaft, T.C.R., 1976. Rinkian mobile belt of West Greenland. In: Escher, A., Stuart Watt, W. (Eds.), Geology of Greenland. Geological Survey of Greenland, pp. 105-119.

Etheridge, M.A., Rutland, R.W.R., Wyborn, L.A.I., 1987. Orogenesis and tectonic process in the Early to Middle Proterozoic of Northern Australia. In: Kröner, A. (Ed.), Proterozoic Lithospheric Evolution. Geodynamics Series, vol. 17, pp. 131-147.

Faure, M., Malavieille, J., 1980. Les plis en fourreau du substratum de la Nappe des Schistes Lustrés de Corse: signification cinématique. C. R. Acad. Sci. Paris (Ser. D) 290, 1349-1352.
Fletcher, J.M., Bartley, J.M., Martin, M.W., Glazner, A.F., Walker, J.D., 1995. Large-magnitude continental extension: an example from the central Mojave metamorphic core complex. Geol. Soc. Am. Bull. 107, 1468-1483.

Fossen, H., 1992. The role of extensional tectonics in Caledonides of South Norway. J. Struct. Geol. 14, 1033-1046.

Fossen, H., 2000. Extensional tectonics in the Caledonides; synorogenic or postorogenic? Tectonics 19, 213-224.

Fossen, H., Holst, T.B., 1995. Northwest-verging folds and the northwestwards movement of the Caledonian Jotun Nappe, Norway. J. Struct. Geol. 17, 3-15.

Fossen, H., Rykkelid, E., 1990. Shear zone structures in the Øygarden area, West Norway. Tectonophysics 174, 385-397.

Fossen, H., Rykkelid, E., 1992. The interaction between oblique and layer-parallel shear in high-strain zones: observations and experiments. Tectonophysics 207, 331-343.

Froitzheim, N., 1992. Formation of recumbent folds during synorogenic crustal extension (Australpine nappes, Switzerland). Geology 20, 923-926.

Gamond, J.F., 1994. Normal faulting and tectonic inversion driven by gravity in a thrusting regime. J. Struct. Geol. 16, 1-9.

Garfunkel, Z., Ron, H., 1985. Block rotation and deformation by strike-slip faults: 2 . The properties of a type of macroscopic discontinuous deformation. J. Geophys. Res., B 90, 8589-8602.

Gartrell, A.P., 1997. Evolution of rift basins and low-angle detachments in multilayer analog models. Geology 25, 615-618.

Gartrell, A.P., 2000. Modes of extension, mobility of the lower crust and the structural evolution of the North West Shelf. Aust. J. Earth Sci. 47, 231-244.

Geist, E.L., Childs, J.R., Scholl, D.W., 1988. The origin of summit basins of the Aleutian ridge: implications for block rotation of an arc massif. Tectonics 7, 327-341.

Govers, R., Wortel, M.J.R., 1993. Initiation of asymmetric extension in continental lithosphere. Tectonophysics 223, 75-96.

Grocott, J., Van den Eeckhout, B., Vissers, R.L.M., 1987. Mantled gneiss antiforms and fold nappes in the Rinkian belt, West Greenland: diapiric structures or structures formed in a thrust system? J. Geol. Soc. (Lond.) 144, 723-734.

Hannula, K.A., Miller, E.L., Dumitru, T.A., Lee, J., Rubin, C.M., 1995. Structural and metamorphic relations in the southwest Seward Peninsula, Alaska: crustal extension and the unroofing of blueschists. Geol. Soc. Am. Bull. 107, 536-553.

Harley, S.L., 1985. Garnet-orthopyroxene bearing granulites from Enderby Land, Antarctica; metamorphic pressure-temperature-time evolution of the Archaean Napier Complex. J. Petrol. 26, 819-856.

Harley, S.L., Black, L.P., 1987. The geological evolution of Enderby Land, Antarctica. In: Park, R.G., Tarney, J. (Eds.), Evolution of the Lewisian and Comparable High Grade Terrains. Geol. Soc. London, Spec. Publ., vol. 27, pp. 285-296.

Harley, S.L., Hensen, B.J., 1990. Archaean and Proterozoic highgrade terranes of East Antarctica $\left(40-80^{\circ} \mathrm{E}\right)$ : a case study of diversity in granulite facies metamorphism. In: Ashworth, J.R., Brown, M. (Eds.), High-Temperature Metamorphism and Crustal Anatexis. Mineral. Soc. Ser., vol. 2, Unwin Hyman, London, pp. $320-370$.

Harley, S.L., Hensen, B.J., Sheraton, J.W., 1990. Two-stage decom- 
pression in orthopyroxene-sillimanite granulites from Forefinger Point, Enderby Land, Antarctica: implication for the evolution of the Archaean Napier Complex. J. Metamorph. Geol. 8, $591-613$.

Harris, L.B., 1993. Correlations between the Central Indian Tectonic Zone and the Albany Mobile Belt of Western Australia: evidence for a continuous Proterozoic orogenic belt. In: Findlay, R.H., Unrug, R., Banks, M.R., Veevers, J.J. (Eds.), Gondwana 8: Assembly, Evolution and Dispersal. A.A. Balkema, Rotterdam, pp. $165-180$.

Harris, L.B., 1994. Neoproterozoic sinistral displacement along the Darling Mobile Belt, Western Australia. J. Geol. Soc. (Lond.) 151, 901-904.

Harris, L.B., 1995. Correlations between the Albany, Fraser and Darling mobile belts of Western Australia and Mirnyy to Windmill Islands in the East Antarctic Shield: implications for Proterozoic Gondwanaland reconstructions. In: Yoshida, M., Santosh, M. (Eds.), India and Antarctica during the Precambrian. Mem. Geol. Soc. India, vol. 33, pp. 47-71.

Harris, L.B., in press. Folding in high-grade rocks due to backrotation between shear zones. J. Struct. Geol.

Harris, L.B., Koyi, H., in press. Centrifuge modelling of folding in high-grade rocks during rifting. J. Struct. Geol.

Harris, L.B., Rivard, B., Corriveau, L., 2001. Structure of the Lac Nominingue-Mont-Laurier region, Central Metasedimentary Belt, Québec Grenville Province. Can. J. Earth Sci. 38, 787-802.

Hills, E.S., 1963. Elements of Structural Geology Methuen and Science Paperbacks, London.

Hill, E.J., Baldwin, S.L., Lister, G.S., 1992. Unroofing of active metamorphic core complexes in the D'Entrecasteaux Islands, Papua New Guinea. Geology 20, 907-910.

Hossock, J.R., Cooper, M.A., 1986. Collision tectonics in the Scandinavian Caledonides. In: Coward, M.P., Ries, A.C. (Eds.), Collision Tectonics. Geol. Soc. Spec. Publ., vol. 19, pp. 287-304.

Huang, C.Y., Yuan, P.B., Lin, C.W., Wang, T.K., Chang, C.P., 2000. Geodynamic processes of Taiwan arc-continent collision and comparison with analogs in Timor, Papua New Guinea, Urals and Corsica. Tectonophysics 325, 1-21.

Hudleston, P.J., 1977. Similar folds, recumbent folds and gravity in ice and rocks. J. Geol. 85, 113-122.

Janecke, S.U., Vandenburg, C.J., Blankenau, J.J., 1998. Geometry, mechanisms and significance of extensional folds from examples in the Rocky Mountains Basin and Range province, USA. J. Struct. Geol. 20, 841-856.

Ji, S., Salisbury, M.H., Hanmer, S., 1993. Petrofabric, P-wave anisotropy and seismic reflectivity of high-grade tectonites. Tectonophysics 222, 195-226.

Jiasheng, Z., Dirks, P.H.G.M., Passchier, C.W., 1994. Extensional collapse and uplift in a polymetamorphic granulite terrain in the Archaean and Palaeoproterozoic of north China. Precambrian Res. 67, 37-57.

Johnson, A.M., Fletcher, R.C., 1994. Folding of Viscous Layers; Mechanical Analysis and Interpretation of Structures in Deformed Rock. Columbia University Press, New York.

Jolivet, L., Goffé, B., 2000. Extensional metamorphic domes in mountains belts, syn-orogenic and post-orogenic extension. C.R. Acad. Sci. Paris, Sci. Terre Planèt. 330, 739-751.
Kay, R.W., Mahlburg, K.S., 1991. Creation and destruction of lower continental crust. Geol. Rundsch. 80, 259-278.

Kay, R.W., Mahlburg, K.S., 1993. Delamination and delamination magmatism. Tectonophysics 219, 177-189.

Klemperer, S., 1988. Crustal thinning and the nature of extension in the North Sea from deep seismic reflection profiling. Tectonics 7, $803-821$.

Koyi, H.A., 1991. Gravity overturn, extension and basement fault activation. J. Petrol. Geol. 14, 117-142.

Koyi, H.A., 1996. Salt flow by aggrading and prograding overburdens. In: Alsop, I., Blundell, D., Davison, I. (Eds.), Salt Tectonic. Geol. Soc. Spec. Publ., vol. 100, pp. 243-258.

Koyi, H.A., Harris, L.B., 2001. Spatial and temporal migration of basin depocenters above low-angle detachments; a centrifugemodel approach. Energ. Explor. Exploit. 19, 365-374.

Koyi, H.A., Skelton, A., 2001. Centrifuge modelling of initiation of low-angle detachment faults. J. Struct. Geol. 23, 1179-1185.

Koyi, H.A., Jenyon, M.K., Petersen, K., 1993. The effect of basement faulting on diapirism. J. Petrol. Geol. 16, 285-312.

Koyi, H.A., Milnes, A.G., Schmeling, H., Talbot, C.J., Juhlin, C., Zeyen, H., 1999. Numerical models of ductile rebound of crustal roots beneath mountain belts. Geophys. J. Int. 139, 556-562.

Kröner, A., Kehelpannala, K.V.W., Kriegsman, L.M., 1994. Origin of compositional layering and mechanisms of crustal thickening in the high-grade gneiss terrain of Sri Lanka. Precambrian Res. $66,21-37$.

Kusznir, N.J., Matthews, D.H., 1988. Deep seismic reflections and deformational mechanics of the continental lithosphere. J. Petrol., Special Lithosphere Issue, 63-87.

Lacassin, R., Mattauer, M., 1985. Kilometre-scale sheath fold at Mattmark and implications for transport direction in the Alps. Nature 316, 739-742.

Lawson, W., Sharp, M.J., Hambrey, M.J., 1994. The structural geology of a surge-type glacier. J. Struct. Geol. 16, 1447-1462.

Lister, G.S., Etheridge, M.A., Symonds, P.A., 1986. Detachment faulting and the evolution of passive continental margins. Geology $14,246-250$.

Lliboutry, L., 1982. Tectonophysique et géodynamique. Une synthèse: géologie structurale, géophysique interné. Masson, Paris.

Lohest, M., 1909. De l'origine des veines et des géodes des terraines primaires de Belgique. Ann. Soc. Géol. Belg. 36B, 275-282.

Long, C., Ji, S., Calvert, A.J., Salisbury, M.H., 1996. Can complex folded structures be correctly imaged by seismic reflection techniques? Eos 77 (Suppl. 17), 183-184.

Lugeon, M., 1941. Une hypothèse sur l'origine du Jura. Bull. Soc. Vaud. Sci. Nat. 61, 465-478.

MacCready, T., Snoke, A.W., Wright, J.E., Howard, K.A., 1997. Midcrustal flow during Tertiary extension in the Ruby Mountains core complex, Nevada. Geol. Soc. Am. Bull. 109, 1576-1594.

Malavieille, J., 1987a. Extensional shearing deformation and kilometre-scale "a"-type folds in a Cordilleran metamorphic core complex (Raft River Mountains, NW Utah). Tectonics 6, 423 448.

Malavieille, J., 1987b. Kinematics of compressional and extensional ductile shearing deformation in a metamorphic core complex of the northeastern Basin and Range. J. Struct. Geol. 9, 541-554. 
Malavieille, J., 1997. Normal faulting and exhumation of metamorphic rocks in mountain belts. In: Sengupta, S. (Ed.), Evolution of Geological Structures in Micro- to Macro-scales. Chapman and Hall, London, pp. 47-57.

Mancktelow, N.S., Pavlis, T.L., 1994. Fold-fault relationships in low-angle detachment systems. Tectonics 13, 668-685.

Mareschal, J.C., 1994. Thermal regime and post-orogenic extension in collision belts. Tectonophysics $238,471-484$

Martignole, J., Calvert, A.J., 1996. Crustalscale shortening and extension across the Grenville Province of western Quebec. Tectonics $15,376-386$.

Mattauer, M., 1975. Sur le mécanisme de déformation de la schistosité dans 1'Himalaya. Earth Planet. Sci. Lett. 28, 144-154.

Mattauer, M., 1981. Plis en fourreau d'échelle plurikilométrique dans la zone interne des Alpes suisses (couverture nord de la nappe du Mont Rose). C. R. Acad. Sci. Paris (Ser. II) 293, 929-932.

McClay, K.R., 1989. Physical models of structural styles during extension. In: Tankard, A.J., Balkwill, H.R. (Eds.), Extensional Tectonics and Stratigraphy of the North Atlantic Margins. Mem. Assoc. Pet. Geol., vol. 46, pp. 95-110.

McGrew, A.J., Peters, M.T., Wright, J.E., 2000. Thermobarometric constraints on the tectonothermal evolution of the East Humboldt Range metamorphic core complex, Nevada. Geol. Soc. Am. Bull. 112, 45-60.

Merle, O., 1994. Nappes et Chevauchements. Masson, Paris.

Merle, O., Vendeville, B., 1992. Modèlisation analogique des chevauchements induits par des intrusions magmatiques. C. R. Acad. Sci. Paris (Ser. II) 315, 1542-1547.

Mezger, K., 1992. Temporal evolution of regional granulite terranes: implications for the formation of lowermost continental crust. In: Fountain, D.M., Arculus, R., Kay, R.W. (Eds.), Continental Lower Crust. Development in Geotectonics, vol. 23, pp. 447478.

Mezger, K., van-der-Pluijm, B.A., Essene, E.J., Halliday, A.N., 1991. Synorogenic collapse; a perspective from the middle crust, the Proterozoic Grenville Orogen. Science 254 (5032), 695-698.

Milnes, A.G., 1997. Alpine and Caledonide tectonics-a brief comparative study. G.F.F. 120, 237-247.

Milnes, A.G., Koestler, A.G., 1985. Geological structure of Jotunheimen, southern Norway (Sognefjell-Valdres cross-section). In: Gee, D.G., Sturt, B.A. (Eds.), The Caledonide OrogenScandinavia and Related Areas 1. Wiley, New York, pp. 457474.

Milnes, A.G., Koyi, H.A., 2000. Ductile rebound of an orogenic root: a case study and numerical model of gravity tectonics in the Western Gneiss Complex, Caledonides, southern Norway. Terra Nova 12, $1-7$.

Milnes, A.G., Wennberg, O.P., Skår, Ø., Koestler, A.G., 1997. Contraction, extension and timing in the south Norwegian Caledonides: the Sognefjord transect. In: Burg, J.P., Ford, M. (Eds.), Geol. Soc. London, Spec. Publ., vol. 121, pp. 123-148.

Molnar, P., Tapponnier, P., 1977. Relation of the tectonics of eastern China to the India-Eurasia collision; application of slip-line field theory to large-scale continental tectonics. Geology 5, 212-216.

Mooney, W.D., Meissner, R., 1992. Multi-genetic origin of crustal reflectivity: a review of seismic profiling of the continental lower crust and Moho. In: Fountain, D.M., Arculus, R., Kay, R.W. (Eds.), Continental Lower Crust. Dev. Geotecton., vol. 23, pp. 45-79.

Moresi, L., 1999a. Extension of a multilayered system. Ellipsis, Solid mechanics research group. http://www.ned.dem.csiro.au/ research/solidMech/PIC/EXAMPLES/Extn.htm.

Moresi, L., 1999b. Tracking composition: intrusions in the crust/ diapirism. Ellipsis, Solid mechanics research group. http:// www.ned.dem.csiro.au/research/solidMech/PIC/EXAMPLES/ Diapirs.htm.

Moresi, L., Boschetti, F., Mühlhaus, H., 1998. Recent developments in the modeling of the emplacement of granites in the crust and their gravity signatures. http://www.agcrc.csiro.au/projects/ 3045CO/CITCOM/PLUTONS/SE-Aust-abs.pdf.

Moresi, L., Muhlhaus, H., Boschetti, F., 2000. Lithosphere instabilities. Models of diapirs intruding the crust. http://www.agcre. csiro.au/projects/3045CO/CITCOM/PLUTONS/.

Motoyoshi, Y., Hensen, B.J., 1989. Sapphirine-quartz-orthopyroxene symplectites after cordierite in the Archaean Napier Complex, Antarctica: evidence for a counterclockwise $P-T$ path? Eur. J. Mineral. 1, 467-471.

Nelson, K.D., 1992. Are crustal thickness variations in old mountain belts like the Appalachians a consequence of lithospheric delamination? Geology 20, 498-502.

Nelson, D.R., 1995. Field guide to the Leeuwin Complex. Australian Conference on Geochronology and Isotope Geoscience. Geological Survey of Western Australia, Perth.

Oldow, J., D’Argenio, B., Ferranti, L., Pappone, G., Marsella, E., Sacchi, M., 1993. Large-scale longitudinal extension in the southern Apennines contractional belt, Italy. Geology 21, $1123-1126$.

Orozco, M., Alonso-Chaves, F.M., Nieto, F., 1998. Development of large north-facing folds and their relation to crustal extension in the Alborán domain (Alpujarras region, Betic Cordilleras, Spain). Tectonophysics 298, 271-295.

Osmundsen, P.T., Andersen, T.B., 1994. Caledonian compressional and late-orogenic extensional deformation in the Staveneset area, Sunnfjord, Western Norway. J. Struct. Geol. 16, 1385-1401.

Passchier, C.W., Myers, J.S., Kröner, A., 1990. Field Geology of High-grade Gneiss Terrains. Springer-Verlag, Berlin.

Phinney, R.A., 1986. A seismic section of the New England Appalachians: the orogen exposed. In: Barazangi, M., Brown, L.D. (Eds.), Reflection Seismology: The Continental Crust. Am. Geophys. Union Geodyn. Ser., vol. 14, pp. 157-172.

Platt, J.P., 1982. Emplacement of a fold-nappe, Betic orogen, southern Spain. Geology 10, 97-102.

Platt, J.P., 1983. Progressive refolding in ductile shear zones. J. Struct. Geol. 5, 619-622.

Platt, J.P., 1986. Dynamics of orogenic wedges and the uplift of high-pressure metamorphic rocks. Geol. Soc. Am. Bull. 97, 1037-1053.

Platt, J.P., Vissers, R.L.M., 1980. Extensional structures in anisotropic rocks. J. Struct. Geol. 2, 397-410.

Platt, J.P., Soto, J.I., Whitehouse, M.J., Hurford, A.J., Kelley, S.P., 1998. Thermal evolution, rate of exhumation, and tectonic significance of metamorphic rocks from the floor of the Alboran 
extensional basin, western Mediterranean. Tectonics 15, 675689.

Plotnikov, L.M., 1994. Shear structures in layered geological bodies. A.A. Balkema, Rotterdam. Russian Translation Series, 104.

Ramberg, H., 1967. Gravity, Deformation, and the Earth's Crust as Studied by Centrifuged Models, 1st edn. Academic Press, London.

Ramberg, H., 1973. Model studies of gravity-controlled tectonics by the centrifuge technique. In: De-Jong, K.A., Scholten, R. (Eds.), Gravity and Tectonics. Wiley, New York, pp. 49-66.

Ramberg, H., 1981. Gravity, Deformation, and the Earth's Crust in Theory, Experiments, and Geological Application, 2nd edn. Academic Press, London.

Ramsay, J.G., Casey, M., Kligfield, R., 1983. Role of shear in development of the Helvetic fold-thrust belt of Switzerland. Geology 11, 439-442.

Ranalli, G., 1997. Rheology of the lithosphere in space and time. In: Burg, J.P., Ford, M. (Eds.), Orogeny Through Time. Geol. Soc. London, Spec. Publ., vol. 121, pp. 19-37.

Rast, N., 1956. The origin and significance of boudinage. Geol. Mag. 93, 401-408.

Reston, T.J., 1990. The structure of the crust and uppermost mantle offshore Britain: deep seismic reflection profiling and crustal cross-sections. In: Salisbury, M.H., Fountain, D.M. (Eds.), Exposed Cross-sections of the Continental Crust. Kluwer, Dordrecht, Boston, pp. 603-621.

Reston, T.J., 1993. Evidence for extensional shear zones in the mantle, offshore Britain, and their implications for the extension of the continental lithosphere. Tectonics 12, 492-506.

Reyer, E., 1888. Theoretische Geologie. Schweizerbart, Stuttgart.

Ron, H., Freund, R., Garfunkel, Z., Nur, A., 1984. Block rotation by strike-slip faulting; structural and paleomagnetic evidence. J. Geophys. Res., B 89, 6256-6270.

Rykkelid, E., Andresen, A., 1994. Late-Caledonian extension in the Ofoten area, northern Norway. Tectonophysics 231, 157-169.

Rykkelid, E., Fossen, H., 1992. Composite fabrics in mid-crustal gneisses: observations from the Øygarden Complex, West Norway Caledonides. J. Struct. Geol. 14, 1-9.

Sandiford, M., 1989. Horizontal structures in granulite terrains: a record of mountain building or mountain collapse? Geology 17 , $449-452$.

Sandiford, M., Powell, R., 1986. Deep crustal metamorphism during continental extension; modern and ancient examples. Earth Planet. Sci. Lett. 79, 151-158.

Sandiford, M., Wilson, C.J.L., 1984. The evolution of the Fyfe Hills-Khmara Bay region, Enderby Land, East Antarctica. Aust. J. Earth Sci. 31, 403-426.

Sawyer, E.W., Barnes, S.J., 1994. Thrusting, magma intraplating, and metamorphic core complex development in the Archaean Belleterre-Angliers greenstone belt, Superior Province, Quebec, Canada. Precambrian Res. 68, 183-200.

Schott, B., 2001. Delamination of the mantle lithosphere from the crust. http://www.geo.uu.nl/ bert/DEL/anim.gif.

Schott, B., Yuen, D.A., Schmeling, H., 2000. The significance of shear heating in continental delamination. Phys. Earth Planet. Inter. 118, 273-290.
Selverstone, J., 1988. Evidence for east-west crustal extension in the eastern Alps: implications for the unroofing history of the Tauern Window. Tectonics 7, 87-105.

Seyitoğlu, G., Çemen, I., Tekeli, O., 2000. Extensional folding in the Alaşehir (Gediz) graben, western Turkey. J. Geol. Soc. (Lond.) 157, 1097-1100.

Snoke, A.W., 1998. Folds and other mesoscopic structural features associated with an extensional mylonitic shear zone. In: Snoke, A.W., Tullis, J., Todd, V.R. (Eds.), Fault Rocks, A Photographic Atlas. Princeton University Press, Princeton, pp. 360-361.

Spencer, J.E., 1982. Origin of folds in Tertiary low-angle fault surfaces, southeastern California and western Arizona. In: Frost, E.G., Martin, D.L. (Eds.), Mesozoic-Cenozoic Tectonic Evolution of the Colorado River Region, California, Nevada and Arizona. Cordilleran Publishers, San Diego, CA, pp. 123-134.

Sylvester, A.G., 1988. Strike-slip faults. Geol. Soc. Am. Bull. 100, $1666-1703$.

van Bemmelen, R.W., 1955. Tectogenèse par gravité. Bull. Soc. Belge Géol. 64, 95-123.

Vernon, R.H., Paterson, S.R., 2001. Axial-surface leucosomes in anatectic migmatites. Tectonophysics 335, 183-192.

Vissers, R.L.M., Platt, J.P., Van der Wal, D., 1995. Late orogenic extension of the Betic Cordillera and the Alboran Domain: a lithospheric view. Tectonics 14, 786-803.

Voggenreiter, W., Hötzl, H., Mechie, J., 1988. Low-angle detachment origin for the Red Sea Rift System. Tectonophysics 150, $51-75$.

Warner, M., McGeary, S., 1987. Seismic reflection coefficients from mantle fault zones. Geophys. J. R. Astron. Soc. 89, 223-230.

Weijermars, R., Jackson, M.P.A., Vendeville, B., 1993. Rheological and tectonic modeling of salt provinces. Tectonophysics 217, $143-174$.

Wennberg, O.P., 1996. Superimposed fabrics due to reversal of shear sense: an example from the Bergen Arc Shear Zone, western Norway. J. Struct. Geol. 18, 871-889.

Wernicke, B., 1985. Uniform-sense normal simple shear of the continental lithosphere. Can. J. Earth Sci. 22, 108-125.

Wernicke, B., 1990. The fluid crustal layer and its implications for continental dynamics. In: Salisbury, M.H., Fountain, D.M. (Eds.), Exposed Cross-sections of the Continental Crust. Kluwer, Dordrecht, Boston, pp. 509-544.

Westaway, R., 1998. Dependence of active normal fault dips on lower-crustal flow regimes. J. Geol. Soc. (Lond.) 155, 233-253.

Wheeler, J., Butler, R.W.H., 1994. Criteria for identifying structures related to true crustal extension in orogens. J. Struct. Geol. 16, $1023-1027$.

Wilde, S.A., Murphy, D.M.K., 1990. The nature and origin of the Late Proterozoic high-grade gneisses of the Leeuwin Block, Western Australia. Precambrian Res. 47, 251-270.

Williams, G.D., 1978. Rotation of contemporary folds into the X direction during overthrust processes in Laksefjord, Finnmark. Tectonophysics 48, 29-40.

Williams, P.F., Goodwin, L.B., Ralser, S., 1994. Ductile deformation processes. In: Hancock, P.L. (Ed.), Continental Deformation. Pergamon, Oxford, pp. 1-27.

Withjack, M.O., Olson, J., Peterson, E., 1990. Experimental models of extensional forced folds. AAPG Bull. 74, 1038-1054. 
Yin, A., 1991. Mechanisms for the formation of domal and basinal detachment faults: a three-dimensional analysis. J. Geophys. Res. 96, 14557-14594.

Zuber, M.T., Parmentier, E.M., Fletcher, R.C., 1986. Extension of the continental lithosphere: a model for two scales of basin and range deformation. J. Geophys. Res. 91, 4826-4838.

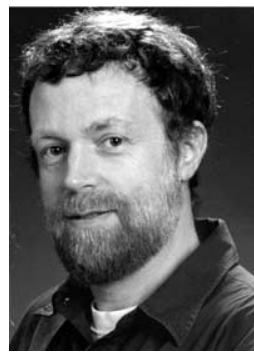

Lyal Harris is a consultant structural geologist and an Honorary Research Fellow at The University of Western Australia (where he was previously Senior Lecturer). Lyal holds a BSc (Hons) degree from the University of Melbourne, Australia, a postgraduate diploma from the University of Montpellier (1980) and a doctorate (1984) from the University of Rennes, France. His research integrates field studies, interpretation of aeromagnetic and satellite imagery and analogue modelling for regional structural and tectonic syntheses and the study of deformation mechanisms. He has worked in high-grade Proterozoic orogens in Australia, India and Canada, fold-thrust belts in Australia, France and Norway, Archaean granite-greenstone terrains in Australia, ophiolites in France and on fault zones in Sumatra. He established an analogue modelling laboratory at UWA and has been using the centrifuge-modelling laboratory in Uppsala, Sweden.

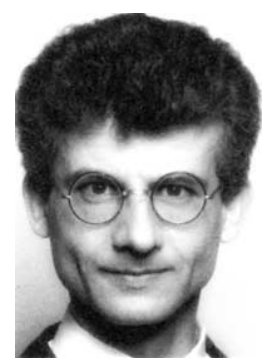

Hemin Koyi is a Senior Researcher at the Hans Ramberg Tectonic Laboratory at Uppsala University where he received both an MSc (1987) and a PhD (1989) in Tectonics and Geodynamics. His research interests focus on modelling geological processes using field and geophysical data. Currently, he works on modelling the effect of sinking denser blocks into salt diapirs targeted for hazardous waste storage. He is a member of the Editorial Board of the Journal of Petroleum Geology and the AAPG European Distinguished Lecture Committee.

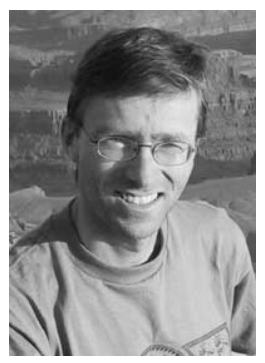

Haakon Fossen is a professor of structural geology at the University of Bergen, Norway. With a combined industrial and academic experience, Haakon's field of research includes thrust tectonics and extensional collapse of the Caledonides, rifting, transpression, ductile shear zone structures, brittle deformation of rock, structure of petroleum reservoirs, physical modelling and theoretical structural geology. He holds a Cand. Mag. degree (1986) from University of Bergen, and a PhD from University of Minnesota, Minneapolis (1992). 